\title{
Off the charts: massive unexplained heterogeneity in a global study of ambiguity attitudes
}

Article

Accepted Version

I'Haridon, O., Vieider, F. M., Aycinena, D., Bandur, A., Belianin, A., Cingl, L., Kothiyal, A. and Martinsson, P. (2018) Off the charts: massive unexplained heterogeneity in a global study of ambiguity attitudes. Review of Economics and Statistics, 100 (4). pp. 664-677. ISSN 1530-9142 doi:

https://doi.org/10.1162/rest_a_00724 Available at https://centaur.reading.ac.uk/72873/

It is advisable to refer to the publisher's version if you intend to cite from the work. See Guidance on citing.

To link to this article DOI: http://dx.doi.org/10.1162/rest_a_00724

Publisher: MIT Press

All outputs in CentAUR are protected by Intellectual Property Rights law, including copyright law. Copyright and IPR is retained by the creators or other copyright holders. Terms and conditions for use of this material are defined in the End User Agreement. 


\section{CentAUR}

Central Archive at the University of Reading

Reading's research outputs online 


\title{
Off the Charts: Massive Unexplained Heterogeneity in a Global Study of Ambiguity Attitudes*
}

\author{
Olivier l'Haridon $^{\dagger} \quad$ Ferdinand M. Vieider ${ }^{\ddagger}$
}

\author{
Diego Aycinena ${ }^{\S}$ Agustinus Bandur $\mathbb{1}$ Alexis Belianin॥ \\ Lubomír Cingl** Amit Kothiyal $^{\dagger \dagger}$ Peter Martinsson ${ }^{\ddagger \ddagger}$
}

September 28, 2017

\begin{abstract}
Ambiguity attitudes have been indicated as important determinants of economic outcomes in economic models, but we still know little about the demographic correlates of ambiguity attitudes, or indeed about the universality of patterns found in the West. We analyse the ambiguity attitudes of almost 3000 students across 30 countries. For gains we find ambiguity aversion everywhere, while ambiguity aversion is much weaker for losses. We also find ambiguity attitudes to systematically change with probabilities for both gains and losses, reflecting ambiguity-insensitivity to probabilities. Much of the between-country variation can be explained through a few macroeconomic characteristics. In contrast, we find massive unexplained variation at the individual level, suggesting that individual differences in ambiguity attitudes remain difficult to explain. We also find much unexplained heterogeneity in individual responses to different decision tasks. We conclude by discussing potential issues underlying this heterogeneity, and indicating potential solutions.
\end{abstract}

Keywords: ambiguity attitudes; cultural comparison; ambiguity aversion; noise

JEL-classification: C91; D81

*Ferdinand Vieider gratefully acknowledges generous financial support from the Excellence Initiative at the University of Munich and the WZB Berlin Social Science Center. Olivier l'Haridon acknowledges financial support from the Institut Universitaire de France and Rennes Metropole District. For the experiments in Costa Rica and Nicaragua we acknowledge financial support by Formas through the COMMONS program. We would like to thank Roy Kouwenberg, Stephen Dimmock, Aurélien Baillon, and Han Bleichrodt for helpful comments. All errors remain our own.

${ }^{\dagger}$ University of Rennes, France

${ }^{\ddagger}$ Department of Economics, University of Reading, UK; Email: f.vieider@reading.ac.uk

$\S$ Universidad Francisco Maroquín, Guatemala

I Bina Nusantara University and Persada Indonesia University, Indonesia

"Higher School of Economics, Moscow, Russia

** Charles University, Prague, Czech Republic

${ }^{\dagger \dagger}$ Max Planck Institute for Human Development, Berlin, Germany

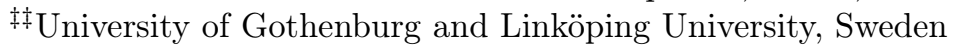




\section{Introduction}

Ambiguity aversion - the preference for known-probability outcome generating processes over normatively equivalent processes in which exact probabilities are not known-has attracted considerable interest since the publication of Daniel Ellsberg's seminal article in 1961. In particular, ambiguity aversion has been indicated as a potential explanation of a wide range of economic outcomes in theoretical models. To name but a few, Mukerji (1998) used ambiguity aversion to explain the existence of incomplete contracts, Easly and O'Hara (2009) used it to explain the stock market participation bias, and Bryan (2010) hypothesised that ambiguity aversion may be causing the low uptake of insurance in developing countries in the presence of basis risk, while Alary, Gollier and Treich (2013) studied the demand for insurance and self-protection under ambiguity aversion. Berger, Bleichrodt and Eeckhoudt (2013) modelled the incidence of ambiguity aversion on treatment decisions where ambiguity could affect either the diagnosis or the treatment itself, with different consequences for medical decisions.

Given the importance ambiguity attitudes have been ascribed in the determination of economic outcomes, it seems crucial to know whether the phenomenon is universal, or whether there exist qualitative or quantitative differences across countries. In this paper, we examine cross-country differences in ambiguity preferences using a rich dataset obtained in experiments with close to 3,000 students from 30 countries. ${ }^{1}$ We further obtain rich measurements of preferences at the individual level, which allow us to investigate the variation of ambiguity attitudes over probability levels (ambiguity-insensitivity to

\footnotetext{
${ }^{1}$ These data were first presented by Vieider, Lefebvre, Bouchouicha, Chmura, Hakimov, Krawczyk and Martinsson (2015a). The latter paper examined risk preferences and uncertainty preferences aggregated over individual choices, and their correlation with survey measures of preferences. It did not in any way discuss ambiguity preferences (here defined as the difference between risk and uncertainty preferences - see below). A second paper based on a subset of the same data, L'Haridon and Vieider (2016), presents a structural analysis of decision making under risk, and does not use the data on uncertainty. We will refer to the latter to contrast our findings for ambiguity to those for risk in the same data set.
} 
probabilities, or a-insensitivity) and for gains versus losses (domain-dependence). This is important inasmuch as ambiguity attitudes have been found to differ systematically across these dimensions (see Trautmann and van de Kuilen, 2015, for a detailed survey), and since such systematic patterns serve to discriminate between different theoretical accounts of behaviour under ambiguity (Baillon and Bleichrodt, 2015).

The conclusions we draw from the data are mixed. At the country level, ambiguity aversion is the standard pattern, albeit with significant quantitative differences between countries. We also find systematic patterns across prospect characteristics, with a-insensitivity prevailing everywhere, and less ambiguity aversion for losses than for gains (although we fail to find much evidence of ambiguity seeking for either losses or small probabilities, as found in many previous studies; see Trautmann and van de Kuilen, 2015). We furthermore manage to explain cross-country differences in ambiguity attitudes recurring to a set of standard variables from the macroeconomic literature.

This picture changes once we move to lower levels of analysis. We find considerable heterogeneity between subjects, but our best attempts at explaining this variance bear little fruit. At $3 \%$ of the variance at the individual level explained by our best model, unexplained heterogeneity remains large even measured against the dismal standard of explaining individual variation in risk preferences (von Gaudecker, van Soest and Wengström, 2011; L'Haridon and Vieider, 2016). This variation could be due either to systematic noise in the responses of some individuals, or to ambiguity attitudes constituting an idiosyncratic trait that is orthogonal to observable characteristics - an issue to which we will return in the discussion.

The situation does not improve when we try to explain differences in behaviour depending on prospect characteristics. A model accounting for all possible prospect char- 
acteristics manages to explain a mere $10-19 \%$ of the residual variance. We interpret the unexplained variance at this level as noise, given the common definition of the latter as capturing calculation mistakes, random responses, or response patterns not captured by the model fit to the data (Train, 2009). The extent of the noise at this level becomes even more evident when comparing it to the performance of the same model for risk preferences, where the explained variance hovers around $75 \%$.

We are not alone in finding poor predictive performance of experimentally measured ambiguity attitudes (for an exception, see Muthukrishnan, Wathieu and Xu, 2009). Giné, Townsend and Vickery (2008) tried to relate experimentally measured ambiguity aversion to insurance uptake in a large field experiment in India, but found no correlation. Borghans, Heckman, Golsteyn and Meijers (2009) found cognitive and psychological characteristics to be predictive of risk attitudes, but not of ambiguity attitudes. Binmore, Stewart and Voorhoeve (2012) could not find any stable demographic correlates of ambiguity attitudes (as well as finding low ambiguity aversion in general; see also Ahn, Choi, Gale and Kariv, 2014). Sutter, Kocher, Glätzle-Rützler and Trautmann (2013) found only weak predictive power of experimentally measured ambiguity attitudes for the behaviour of adolescents. Stahl (2014) also detected high levels of noise in an experimental study of ambiguity attitudes. Even Dimmock, Kouwenberg and Wakker (2015a), while finding some correlations in a representative sample of the Dutch population, manage to explain at most around $5 \%$ in the variation of their ambiguity indices - a proportion that roughly corresponds to the one we report in our own data.

We cannot fully exclude that some of these findings may be driven by our measurement method. We measure ambiguity attitudes using two certainty equivalents $(C E s)$, one for risk (known probabilities) and one for uncertainty (unknown probabilities), and 
construct an ambiguity premium from the difference of the two. CEs have been shown to provide an unbiased measure of ambiguity attitudes (Trautmann, Vieider and Wakker, 2011), and they are popular in the literature (Abdellaoui, Baillon, Placido and Wakker, 2011; Sutter et al., 2013). They are easily to implement, including in paper-and-pencil experiments, straightforward to incentivize, and they have the great advantage of being simple to administer and to understand. Furthermore, they allow for a model-free analysis of ambiguity attitudes. Given that the method consists of two separate measurements for risk and uncertainty attitudes, there could, however, be an accumulation of error terms when deriving our ambiguity premia. Some recent papers have used direct measurements of ambiguity aversion by matching probabilities, and have reported some success in correlating the measures to real world behaviour (Dimmock et al., 2015a; Dimmock, Kouwenberg, Mitchell and Peijnenburg, 2015b). We will provide a more detailed examination of measurement errors across different tasks in the discussion.

We do not mean to conclude from our results that ambiguity aversion is not an empirically meaningful concept. The use of abstract urns and the comparison of extreme situations of completely known and completely unknown probabilities, however, seem to induce high levels of inconsistencies in responses, which may well result from the salient and artificially induced absence of information from one of the urns (Frisch and Baron, 1988; Fox and Tversky, 1995). These issues may then be further exacerbated by measurement problems, which are also well-known in the risk preference literature. One solution for applied empirical researchers may then be to recur to more natural sources of uncertainty (Abdellaoui et al., 2011; Baillon, Huang, Selim and Wakker, 2016b). In addition, it appears crucial to obtain a better understanding of measurement issues affecting our estimates of ambiguity attitudes, and comparative evidence on the relative 
merit of different measurement tools. We will return to both these issues in the discussion.

\section{Experiment and analysis}

\section{$2.1 \quad$ The experiment}

We conducted the same experiment in 30 countries. The countries were selected with an eye to diversification along several dimensions that were deemed potentially important for our study. These included inter alia geographic representation and extension, level of income per capita, and importance in economic and population terms. A total of 2939 subjects participated in the experimental sessions. Students were used since they were deemed more comparable across countries than other population groups. Subjects were recruited at major public universities in the different countries, with a few exceptions where no collaborators at public universities could be found (Brazil, Guatemala, Malaysia, Saudi Arabia, and Tunisia). Care was taken to obtain a subject sample that was balanced in terms of sex and study major, although this was not always successful (e.g. in Saudi Arabia only males could be recruited because our male contact was not allowed to interact with female students). In universities with a standing subject pool we only recruited subjects who had participated in at most 2 experiments before, so that they would be similar to subjects in developing countries for whom experiments were new. Appendix A provides a summary of the main subject characteristics country by country.

All experiments were run between September 2011 and October 2012. Experiments across countries were kept as comparable as possible. The experiment was run in the teaching language of the university, since many countries included in the study are multilingual, so that the official teaching language is the only one shared by all students. 
Instructions were translated from English and back-translated into English by a different person (Brislin, 1970). Differences were then eliminated by discussion. The payoffs were carefully converted using World Bank PPP data and then double checked using PPP conversion rates calculated from net wages of student assistants at the university where the experiments took place. Vieider (2012) tested explicitly whether small variations in payoffs in the order of $\pm 20 \%$ would make a difference in terms of measured risk or uncertainty attitudes and found none. Also, the experiment was run in two different cities in China - Beijing and Shanghai - and on two different campuses in Addis Ababa, Ethiopia, to determine whether differences found could be ascribed to differences in the subject pool, which would be troubling for an international comparison. No such differences were found once observable subject characteristics had been controlled for-see Vieider, Chmura, Fisher, Kusakawa, Martinsson, Mattison Thompson and Sunday (2015b). Subjects were reassured of their anonymity - an element that is potentially important for measures of ambiguity, as the potential for scrutiny may increase ambiguity aversion (Baltussen, van den Assem and van Dolder, 2016).

We elicited certainty equivalents for 44 binary prospects which differed by outcomes, probabilities, decision domain (gains versus losses) and source of uncertainty (known probabilities versus vague probabilities). In this paper, we concentrate specifically on the 16 pairs of prospects that were administered both using objective and vague probabilities. Table 1 shows the decision tasks used in this paper, where a single prospects is represented as $(p: x ; y)$, where $p$ is the probability of winning or losing $x$, and $y$ obtains with a probability $1-p$. For our main analysis, we will focus on the prospect pairs with $y=0$, since this simplifies our analysis considerably at little or no cost in terms of insights. We use the four additional prospect pairs with a lower outcome $y \neq 0$ for consistency checks 
and out-of-sample predictions.

Subjects were asked to make a choice between the prospect and different sure amounts of money contained between $y$ and $x$. For gains, the sure amounts increased from $y$ to $x$. For losses, the sure amount decreased from $-y$ to $-x$. For gains, subjects will generally choose the prospect for small sure amounts and switch to preferring the sure amount as the latter gets larger (and vice versa for losses). The certainty equivalent $(C E)$ of a subject was encoded as the average of the last sure amount for which the prospect was chosen and the first sure amount chosen (vice versa for losses).

Table 1: decision tasks, amounts in PPP Euros

\begin{tabular}{cc}
\hline gains & losses \\
\hline$(1 / 8: 20 ; 0)$ & $(1 / 8:-20 ; 0)$ \\
$(1 / 8: 20 ; 5)$ & $(1 / 8:-20 ;-5)$ \\
$(2 / 8: 20 ; 0)$ & $(2 / 8:-20 ; 0)$ \\
$(3 / 8: 20 ; 0)$ & $(3 / 8:-20 ; 0)$ \\
$(5 / 8: 20 ; 0)$ & $(5 / 8:-20 ; 0)$ \\
$(6 / 8: 20 ; 0)$ & $(6 / 8:-20 ; 0)$ \\
$(7 / 8: 20 ; 0)$ & $(7 / 8:-20 ; 0)$ \\
$(7 / 8: 20 ; 5)$ & $(7 / 8:-20 ;-5)$ \\
\hline
\end{tabular}

The tasks were distributed across different categories and domains (see online appendix for the full experimental instructions). By decision domain we mean that choices were framed either as gains or as losses. Losses were always administered in a second part of the experiment and took place from an endowment. This endowment was given conditional on the second part being selected for real play, and was equivalent to the highest loss of $€ 20$ no matter what the selected choice. Etchart-Vincent and L'Haridon (2011) tested whether decisions from an endowment are different from decisions involving real losses and found no differences. In each of the two domains, we had tasks with known probabilities, which we call risky; and decisions involving unknown probabilities, which we call uncertain. The tasks were always kept in the same order, starting with risky gains 
and then uncertain gains; and in a second part, risky losses followed by uncertain losses. This was done so as to facilitate the logistics and avoid mix-ups, as well as to reduce the cognitive burden on subjects. A large-scale pilot with 330 subjects showed that such a fixed ordering was less demanding for subjects, while not significantly affecting the measures used in this paper.
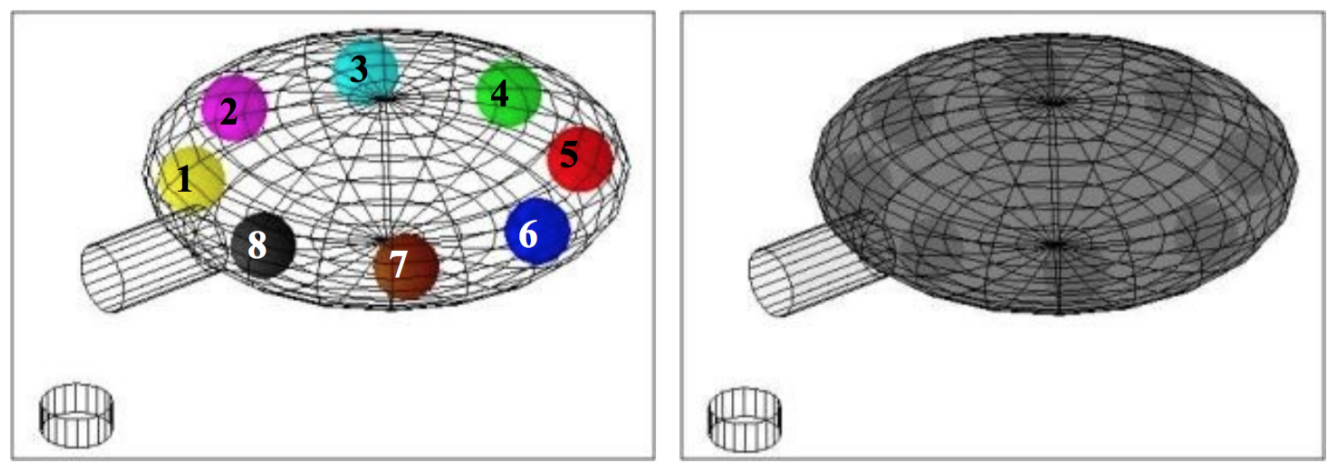

Figure 1: Risky urn (left) and uncertain urn (right)

An example of the representation of risky and uncertainty urns, which follows the representation used by Abdellaoui et al. (2011), can be seen in figure 1. In the experiment, the urns were not called risky or uncertain, but rather "transparent" and "opaque". Concerning the risky urn, subjects simply learned that the urn contained exactly eight balls, numbered from 1 to 8 inclusive. About the uncertain urn they were told: "you cannot see what numbers the balls contained in the urn have. This means that you do not know the exact numbers that are present in that urn. All balls bear a number between 1 and 8 inclusive (have either $1,2,3,4,5,6,7$, or 8 written on them), but it is possible that some numbers are absent from this urn while others occur repeatedly. Thus you do not know the exact composition of the urn." This implementation of uncertainty permits to centre the uncertainty around a known probability distribution. In this sense, a prospect offering a given prize when a ball with the number 1 or 2 is extracted offers a vague probability interval that is centred on a probability of $2 / 8$. The vagueness derives 
from the fact that the probability may in reality be lower or higher than $2 / 8$.

Due to logistic reasons, we could not allow subjects to choose the colours on which to bet. This may result in distrust of the experimenter to contaminate the results (Charness, Karni and Levin, 2013), although others studies failed to find such effects (Oechssler and Roomets, 2015), and the evidence accumulated to date on the relevance of this issue is inconclusive (Trautmann and van de Kuilen, 2015). We took two steps to counteract this issue. First, we explicitly encouraged subjects to check the contents of the ambiguous urn after the experiment. This was meant to reassure them that, while some balls could be absent from the urn as described in the instructions, we did not systematically manipulate the urn to their disadvantage. Second, we conducted a pilot on whether letting subjects choose the winning number of the balls would make a difference in our particular design. We did not find any evidence that this was the case - the online appendix provides details about this pilot. We will furthermore see in due time that the data do not appear to support explanations based on suspicion against the experimenter (see also Dimmock et al., 2015b, for further evidence on this). ${ }^{2}$

\subsection{Analysis and econometrics}

For our analysis, we construct ambiguity premia in the following way. We have eight certainty equivalents $(C E s)$ for uncertain gains and eight CEs for uncertain losses. We contrast them with the equivalent risky CEs for which probabilities are known. The ambiguity premium is then defined as:

\footnotetext{
${ }^{2}$ One may also argue that, in some sense, dislike of asymmetric knowledge by the experimenter is a part of ambiguity aversion. For instance, Chow and Sarin (2002) showed that subjects disliked the information asymmetry inherent in the ambiguity problem, even when distrust of the experimenter was completely excluded.
} 


$$
\pi_{s i}=\frac{c e_{s i}^{r}-c e_{s i}^{u}}{x_{s i}-y_{s i}}
$$

where the subscript $s$ indicates the sign (gains or losses), $i$ indicates the probability level or prospect, and the superscripts $r$ and $u$ indicate risk and uncertainty respectively. ${ }^{3}$ The division by the outcome range of the prospect serves to normalise the value of the certainty equivalent. A CE under uncertainty that is smaller than the corresponding CE under risk thus indicates ambiguity aversion for both gains and losses. The normalization allows us to interpret the difference directly on a probability scale. For instance, an ambiguity premium of 0.1 signifies that a decision maker is willing to give up an additional 10 percentage points of the probability of winning the extra prize $x-y$ in order to avoid ambiguity, measured against her risk aversion.

Our index of ambiguity attitudes is completely model-free. To show this, it is instructive to examine the relation of our ambiguity premium to other measures used in the literature, and particularly the ones derived from matching probabilities by Dimmock et al. (2015a). Following the latter in applying the source method of Abdellaoui et al. (2011) to our stimuli (see Dimmock et al., 2015a, section 3.2 for a detailed discussion of the theoretical assumptions), and dropping the subscripts si to the prospect characteristics to avoid notational clutter, we can define our certainty equivalent under risk as

$$
c e^{r}=u^{-1}\left[w_{s}^{r}(p) u(x)+\left(1-w_{s}^{r}(p)\right) u(y)\right]
$$

where $u$ is a utility function transforming outcomes into utiles, and $w$ is a source- or probability weighting function transforming probabilities into decision weights, and the

\footnotetext{
${ }^{3}$ In particular, we can obtain a normalised certainty equivalent for risk, $\pi_{s i}^{r}=\frac{c e_{s i}^{r}-y_{s i}}{x_{s i}-y_{s i}}$, and a normalised certainty equivalent for uncertainty, $\pi_{s i}^{u}=\frac{c e_{s i}^{u}-y_{s i}}{x_{s i}-y_{s i}}$. Equation 1 then results from $\pi_{s i}^{r}-\pi_{s i}^{u}$.
} 
power -1 indicates the inverse of the utility function. The superscript $r$ to $w$ serves to remind us that this function is applied to objectively given probabilities or risk, while the subscript $s$ emphasises its sign-dependence. Now take an uncertain event $E$ to represent likelihoods in our uncertain urn. Assigning a probability $P(E)$ to the uncertain event, we can now derive the $\mathrm{CE}$ under uncertainty as follows:

$$
c e^{u}=U^{-1}\left[w_{s}^{u}(P(E)) U(x)+\left(1-w_{s}^{u}(P(E))\right) U(y)\right],
$$

where $U$ denotes utility under uncertainty, and the superscript $u$ to $w$ indicates that this is the source function for uncertainty. Assuming $y=0$ for simplicity (the reasoning is similar for $y \neq 0$ ), and normalizing utility such that $u(0)=U(0)=0$ and $u(x)=U(x)=1$, we can write the ambiguity premium as

$$
\pi=\frac{u^{-1}\left[w_{s}^{r}(p)\right]-U^{-1}\left[w_{s}^{u}(P(E))\right]}{x-y}
$$

Equation 4 shows that our ambiguity premia capture not only differences in decision weights, but also any potential differences in utility between risk and uncertainty. By assuming equality in utility between risk and uncertainty, matching probabilities only capture differences in decision weights. Thus if utility is different between risk and uncertainty but decision weights are not, the matching probabilities will not detect ambiguity attitudes, but our ambiguity premia will.

We analyse the data using a hierarchical or multilevel model with three levels of analysis (see Snijders and Bosker, 2012, for an introduction to multilevel modelling). Our fundamental unit of analysis are ambiguity premia for single prospect comparisons, of the type indicated in equation 1 . The next higher level is constituted by subjects, so that 
the standard errors are clustered at that level and we can capture the between-subject variance. The highest level is constituted by countries. We express this as

$$
\pi_{i n c}=\beta_{0}+X_{i n c} \beta_{n c}+\nu_{c}+\mu_{n c}+\varepsilon_{i n c}
$$

where $i$ is now a running index including all prospect characteristics, having dropped $s$ to avoid notation overload. The part $X_{i n c} \beta_{n c}$ constitutes the so-called fixed part of the model, with $X$ containing observable characteristics at the prospect $(i)$, individual $(n)$, and country $(c)$ level, and $\beta$ constituting a vector of regression coefficients. The remaining part of the equation is referred to as the random part, with $\nu_{c}$ capturing the random intercept at the country level, and $\mu_{n c}$ the random intercept at the subject level. These two terms thus capture systematic variation in the residuals at these two levels. The remaining term $\varepsilon_{i n c}$ captures the residual variance of the model. By using an empty set of observables $X$ and dropping the fixed part of the model, we can estimate a baseline model that purely quantifies the variance at the different levels of analysis. The extent to which the variance at various levels is reduced by adding independent variables at the different levels to $X$ then serves to assess our success in explaining the overall variation in the data. We will run all regressions separately for gains and losses. While it is in principle possible to run one large regression on all ambiguity premia, this requires interaction terms to be included at all times, given the opposite signs for gains and losses. Running two separate regressions for gains and losses thus avoids having to run triple interactions when considering crossed effects.

The random intercepts captured in $\nu$ and $\mu$ allow the intercept to be different by country and by subject within countries and thus capture general differences in ambiguity aversion, while the regressands contained in $X$ are forced to show the same effect for the 
whole sample. This has the advantage of quantifying the variance at each level, while adjusting the standard errors for the level of analysis. While the above model constitutes a first step in the direction of accounting for heterogeneity on various levels, the assumption of equal effects of observable characteristics across different levels is still unsatisfactory. In particular, we may want to allow for the possibility that individual-level regression results may differ between countries, for instance, to what extent the gender effect in ambiguity attitudes is different across countries. We thus amend our model by allowing for so-called random slopes:

$$
\pi_{i n c}=\beta_{0}+X_{i n c} \beta_{n c}+Y_{i n} \nu_{c}+Z_{i} \mu_{n c}+\varepsilon_{i n c} .
$$

Thus we now also allow the effects of prospect and individual characteristics to differ across subjects and countries. For instance, $Y_{i n}$ may contain both prospect characteristics, such as the probability of winning in a given prospect, and individual characteristics, such as for instance a female dummy. The prospect characteristic would capture differences in the effect of prospect characteristics across countries, in our example differential effects of the probability of winning across countries. For the latter, we may furthermore observe differences across subjects, e.g. different subjects may react differently to the probability of winning. This is captured by inserting prospect characteristics as random slopes at the individual level into $Z_{i}$.

The results then correspond to those of an OLS regression, with standard errors adjusted for the specific level of analysis. The probability inserted as an explanatory characteristic into matrix $Y$ will allow us to quantify a-insensitivity, the phenomenon by which ambiguity attitudes change less than proportionally with the probability of winning. Technically, a-insensitivity in a given country is indeed simply measured by 
the regression coefficient of probability at this level, with a positive value indicating ainsensitivity, a zero coefficient indicating perfect sensitivity, and a negative coefficient indicating excess sensitivity. The random intercept measures the level of ambiguity aversion. Inserting the probability into $Z$ will achieve the same at the individual level, i.e. it will capture heterogeneity in reactions to probabilities across subjects. ${ }^{4}$ Finally, inserting the probability into the fixed part $X$ and comparing this to a baseline model empty of covariates will allow us to determine to what extent we can reduce the residual variance $\varepsilon$ by controlling for this prospect characteristic.

\section{Results}

We present the results in several steps. We start with a nonparametric analysis of the ambiguity premia. We then proceed to documenting differences between countries using random intercepts - which serve to quantify country-level differences in aggregate ambiguity aversion - and random slopes for probability - which quantify between-country differences in a-insensitivity. We then quantify the variance in the data and explore the extent to which we can explain the overall level of variance observed at each of the three levels - between countries, between individuals, and between ambiguity premia.

\subsection{Descriptive results}

We start by presenting some descriptives of the nonparametric data. Figure 2 shows the average ambiguity premia per country, together with their $95 \%$ confidence intervals. The premia were obtained in the following way. We first calculated the average ambiguity

\footnotetext{
${ }^{4}$ This linear regression approach is again close in spirit to the approach used by Dimmock et al. (2015a). Indeed, it can be shown that under the assumption of linear utility and neoadditive probability weighting, our indices are closely related to theirs, although they do not coincide exactly.
} 
premium per subject, separately for gains and losses. We then took the average of this mean premium per country, again separately by decision domain.

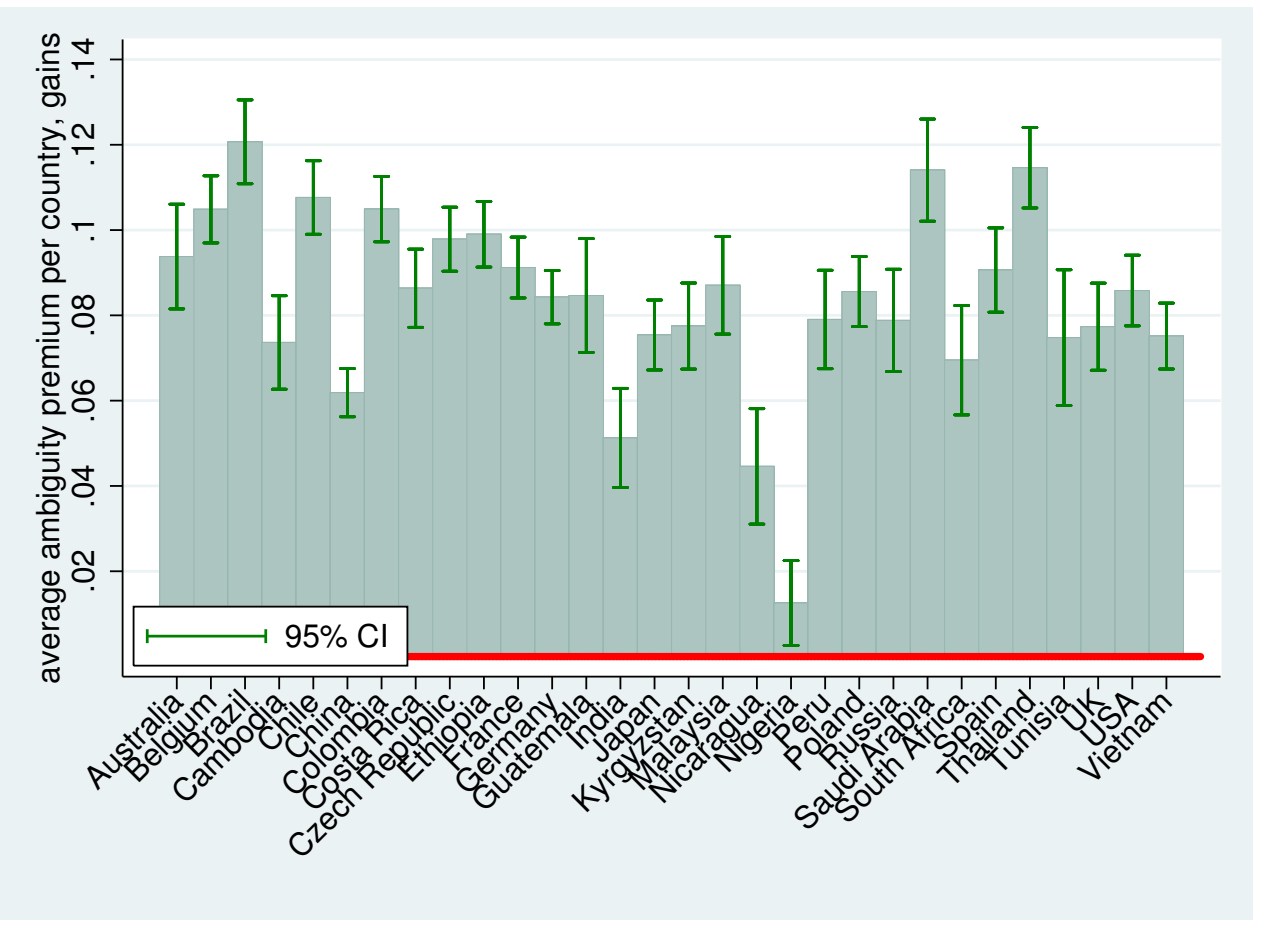

(a) gains

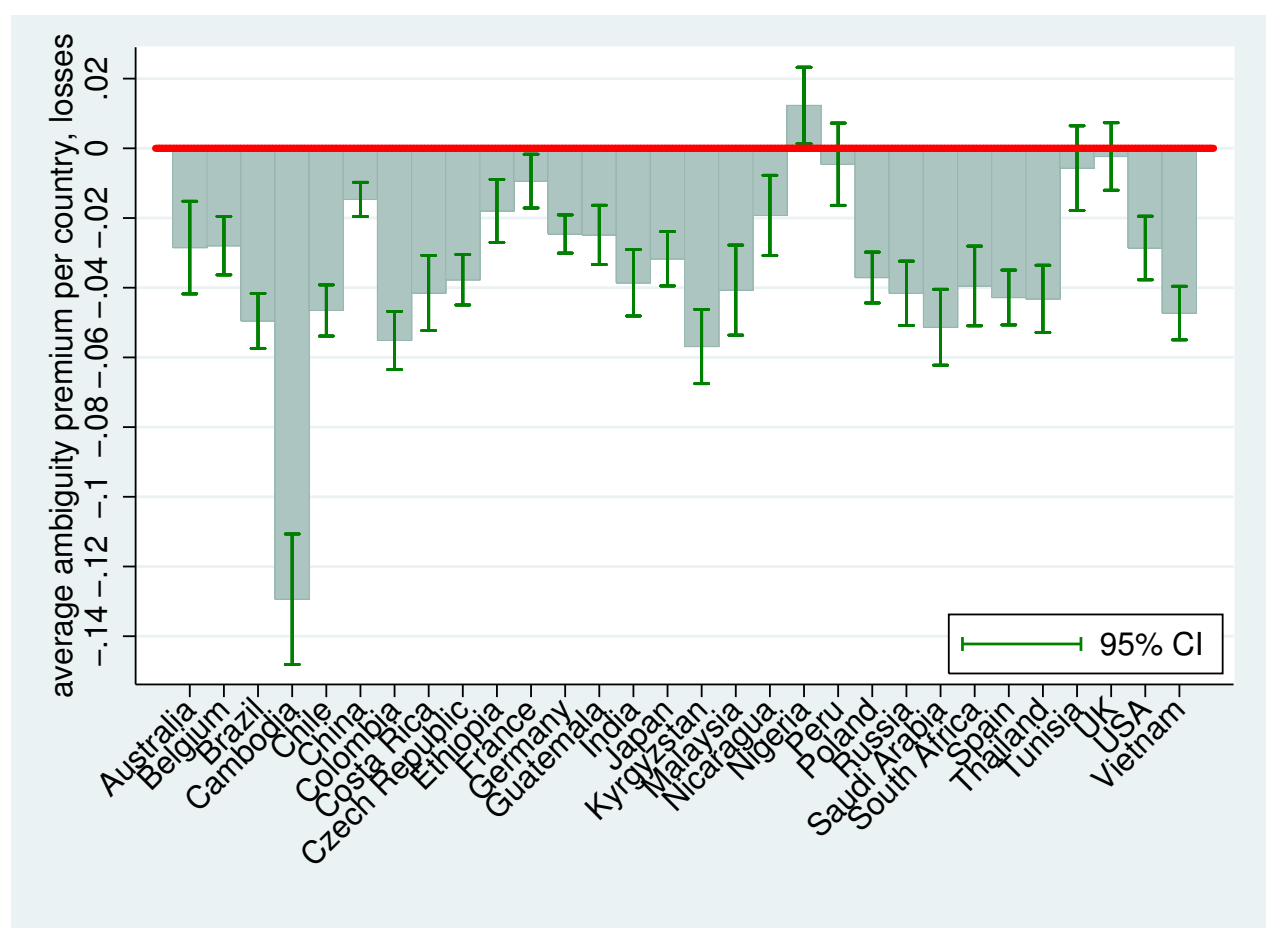

(b) losses

Figure 2: Average ambiguity premia by country for gains and losses with $95 \%$ confidence intervals

Figure 2(a) shows the premia thus obtained for gains. We find significant ambiguity 
aversion on average in all countries. At the same time, there is significant heterogeneity in average ambiguity attitudes across countries. The premia can be interpreted on a probability scale, meaning that for instance subjects in Belgium are on average willing to sacrifice 10 percentage points of the probability of winning to play a risky rather than an ambiguous prospect. Figure 2(b) shows the average ambiguity premia per country for losses, where a positive premium now indicates ambiguity seeking. Most country premia are negative, showing that the prevalent pattern is still one of ambiguity aversion. This ambiguity aversion is considerably weaker than for gains (with the exception of Cambodia, where ambiguity aversion for losses is extremely strong). For a few countries, such as Peru, Tunisia, and the UK, we cannot exclude ambiguity neutrality, while Nigeria again stands out from the general trend, this time by showing ambiguity seeking. Lower levels of ambiguity aversion for losses than for gains are consistent with previous evidence. Cohen, Jaffray and Said (1987) found ambiguity aversion for gains, but ambiguity neutrality for losses. Similar results were obtained among others by Friedl, Miranda and Schmidt (2014). We do, however, not find much evidence for ambiguity seeking for losses. This contrasts with the previous literature, where most of the studies report either ambiguity neutrality or ambiguity seeking for losses (see Trautmann and van de Kuilen, 2015).

We have so far only looked at average attitudes per subject. This masks the fact that ambiguity attitudes have been found to differ systematically across the probability spectrum (Tversky and Fox, 1995; Abdellaoui et al., 2011). Figure 3 depicts ambiguity attitudes by probability level, aggregating over the whole sample across subjects and countries. For gains, we find relatively low ambiguity aversion for small probabilities, with ambiguity aversion increasing as probabilities get larger. A jump occurs between $p=3 / 8$ and $p=5 / 8$, which suggests that people are particularly insensitive to changes 


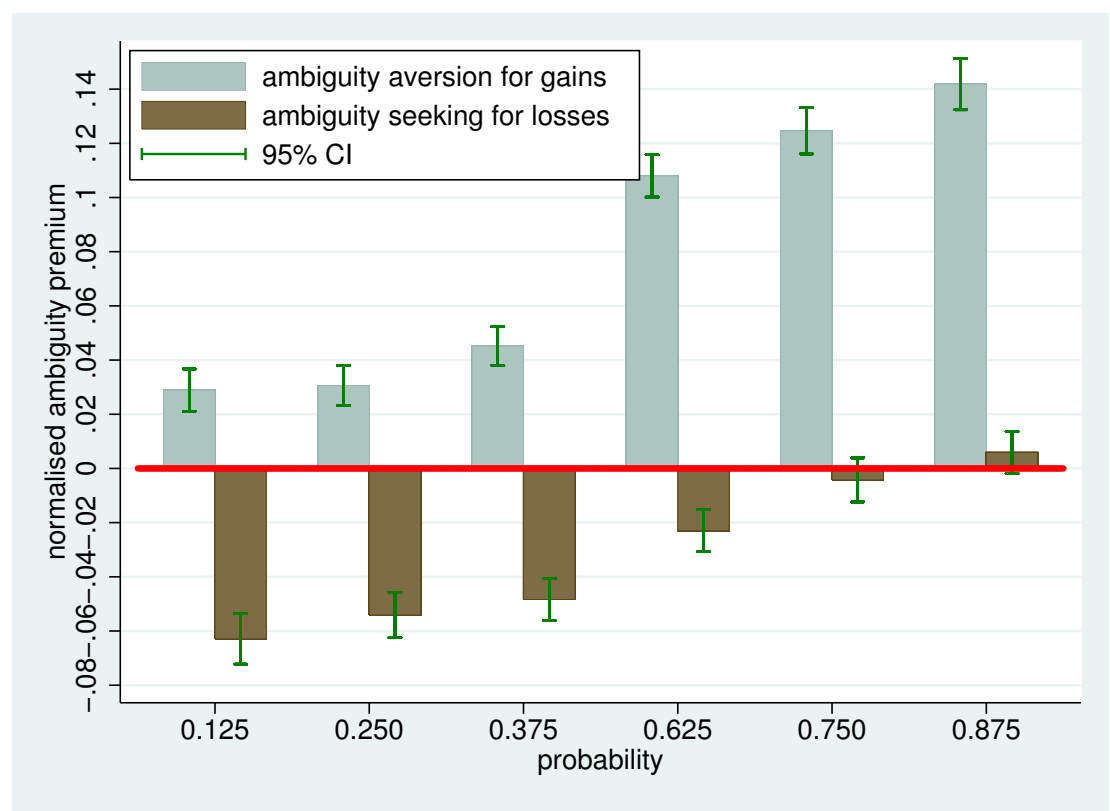

Figure 3: Ambiguity aversion by probability

in probability to either side of $p=0.5$. For losses, we find the exact opposite pattern. Ambiguity aversion starts out large for small probabilities, and becomes smaller as probabilities increase, resulting in a trend towards ambiguity seeking for the largest probability (although this fails to reach significance in the aggregate data). There also is a similar jump around the middle of the probability spectrum as observed for gains.

Most previous studies have found ambiguity seeking for small probability gains (Dimmock et al., 2015a), but some have found attitudes closer to ambiguity neutrality for the same type of prospects (Abdellaoui et al., 2011). The reason for this may well be that previous studies that found ambiguity seeking used comparative environments, in which uncertainty was directly compared to risk. In our design there is no direct comparison, and we elicited certainty equivalents for risk and uncertainty separately, in separate blocks of the experiment. It is well known that ambiguity attitudes are strongest in settings that allow for the direct comparison of objectively given and vague probabilities (Fox and Tversky, 1995; Chow and Sarin, 2001). In this sense, our measures can be seen as a lower bound on ambiguity attitudes. Bouchouicha, Martinsson, Medhin and Vieider 
(2016) furthermore report evidence that a-insensitivity increases in monetary stakes, so that ambiguity seeking for small probabilities may only emerge at higher stake levels. While they found no evidence for ambiguity seeking at small probabilities for the stake levels used here, such ambiguity seeking started to emerge once stakes were doubled.

\subsection{Ambiguity aversion and a-insensitivity by country}

We start our parametric analysis by quantifying the aggregate ambiguity aversion and a-insensitivity at the country level for gains and losses. We quantify the two measures by running multilevel regressions separately for gains and losses, and using probability as the sole explanatory variable, whereby we normalise the probability to be centred around 0.5 (i.e., we take $p-0.5$ ). We further obtain random slopes for probabilities at the country level, allowing us to investigate differences in a-insensitivity across countries.

Figure 4 shows scatter plots of the two measures for gains and losses, with panel 4(a) showing a scatter plot of ambiguity attitudes for gains and losses, and panel 4(b) showing a scatter plot of a-insensitivity for gains and losses. Ambiguity attitudes for gains and losses show a clear negative correlation at the country level $(\rho=-0.44, p=0.017)$. Given the inverse interpretation for gains and losses, this means that ambiguity aversion for gains is negatively correlated with ambiguity seeking for losses. A-insensitivity, indicated in panel 4(b), shows a clear positive correlation across domains $(\rho=0.74, p<0.001)$. Overall, the patterns we observe at the country level thus indicate a remarkable stability of ambiguity attitudes between gains and losses. 


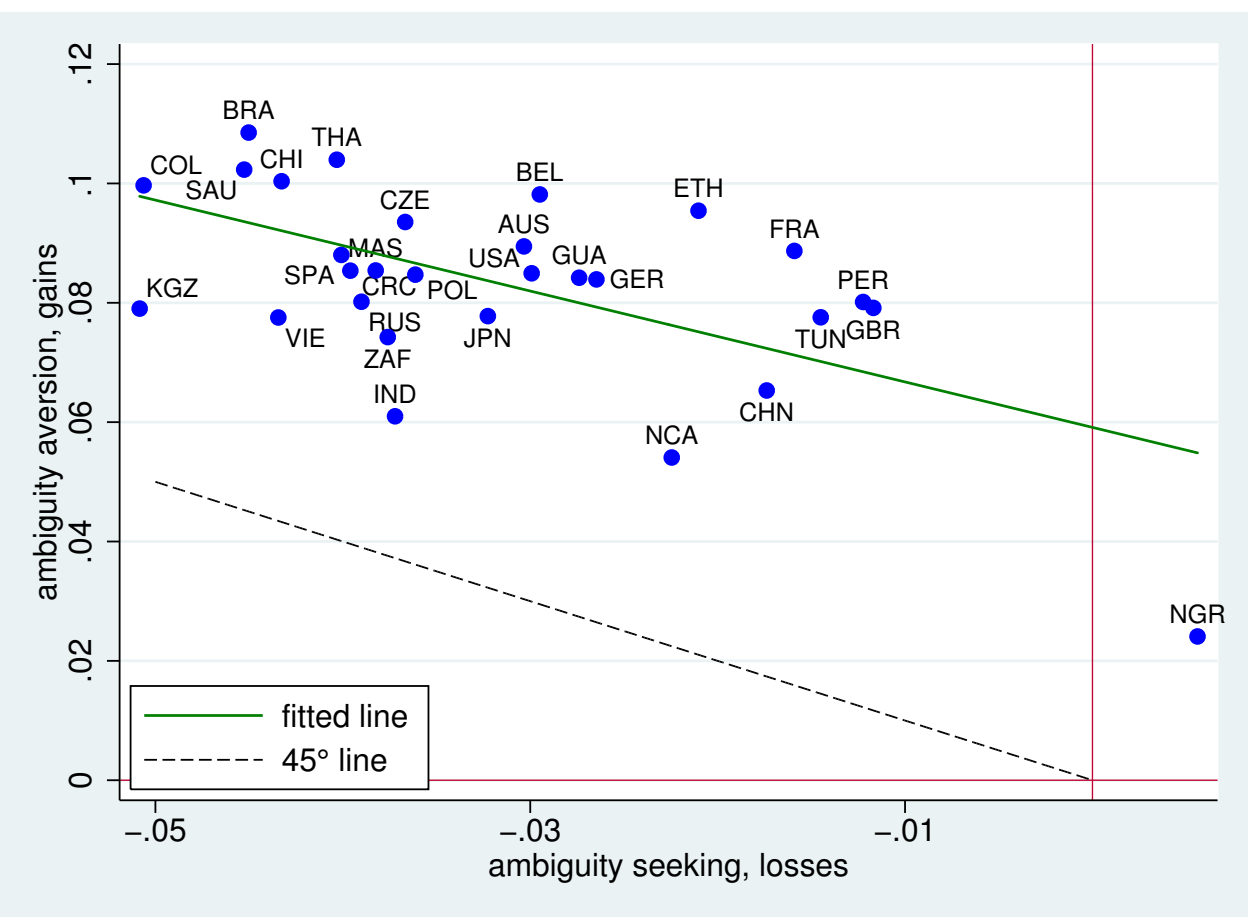

(a) ambiguity aversion

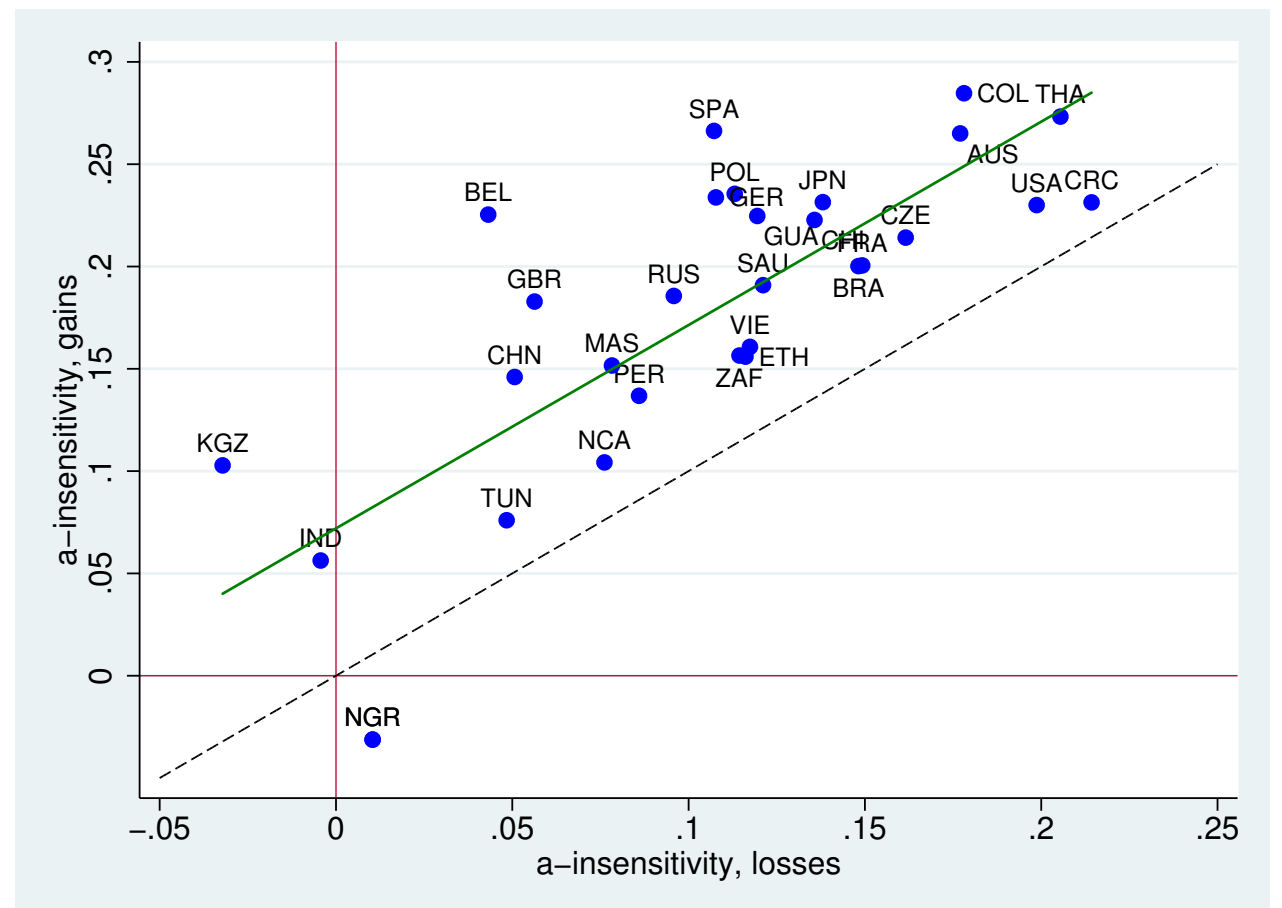

(b) a-insensitivity

Figure 4: Scatter plots of ambiguity aversion and a-insensitivity for gains and losses. NOTE: Cambodia is excluded from both graphs since it constitutes an outlier 


\subsection{Explaining residual variance (within-subjects)}

We will now try and see how much of the variation in ambiguity premia we can explain at the prospect or premium level, or in other words, to what extent we can explain the residual variance in our model. Table 2 shows regressions of the ambiguity premia on a number of prospect characteristics. The first data column presents a benchmark model empty of covariates that serves purely to quantify the variance at the various levels. At the residual level, we observe a value of 0.043 for gains, corresponding to about $84 \%$ of the overall variance. The picture is similar for losses, where again about $84 \%$ of the variance is to be found at the residual level. ${ }^{5}$ The goal of the subsequent regressions will now be to see how much of this variance we can explain through characteristics of the choice problem.

Table 2: Residual level regressions

\begin{tabular}{|c|c|c|c|c|c|c|c|c|}
\hline & \multicolumn{4}{|c|}{ gains (ambiguity aversion) } & \multicolumn{4}{|c|}{ losses (ambiguity seeking) } \\
\hline & benchmark & model I & model II & model III & benchmark & model I & model II & model III \\
\hline probability & & $\begin{array}{c}0.168^{* * *} \\
(0.020)\end{array}$ & $\begin{array}{c}0.100^{* * *} \\
(0.020)\end{array}$ & $\begin{array}{c}0.100^{* * *} \\
(0.020)\end{array}$ & & $\begin{array}{c}0.095^{* * *} \\
(0.017)\end{array}$ & $\begin{array}{c}0.087^{* * *} \\
(0.017)\end{array}$ & $\begin{array}{c}0.087^{* * *} \\
(0.017)\end{array}$ \\
\hline$p>0.5$ dummy & & & $\begin{array}{c}0.040^{* * *} \\
(0.008)\end{array}$ & $\begin{array}{c}0.040^{* * *} \\
(0.008)\end{array}$ & & & $\begin{array}{c}0.005 \\
(0.008)\end{array}$ & $\begin{array}{c}0.005 \\
(0.008)\end{array}$ \\
\hline random slopes & & & & $\checkmark$ & & & & $\checkmark$ \\
\hline constant & $\begin{array}{c}0.083^{* * *} \\
(0.004)\end{array}$ & $\begin{array}{l}-0.001 \\
(0.007)\end{array}$ & $\begin{array}{l}0.013^{*} \\
(0.007)\end{array}$ & $\begin{array}{l}0.011^{*} \\
(0.006)\end{array}$ & $\begin{array}{c}-0.034^{* * *} \\
(0.005)\end{array}$ & $\begin{array}{c}-0.081^{* * *} \\
(0.009)\end{array}$ & $\begin{array}{c}-0.079^{* * *} \\
(0.009)\end{array}$ & $\begin{array}{c}-0.079^{* * *} \\
(0.009)\end{array}$ \\
\hline country VAR & $\begin{array}{c}0.000^{* * *} \\
(0.000)\end{array}$ & $\begin{array}{c}0.000^{* * *} * \\
(0.000)\end{array}$ & $\begin{array}{c}0.000^{* * *} \\
(0.000)\end{array}$ & $\begin{array}{c}0.000^{* * * *} \\
(0.000)\end{array}$ & $\begin{array}{c}0.000^{* * *} \\
(0.000)\end{array}$ & $\begin{array}{c}0.000^{* * *} \\
(0.000)\end{array}$ & $\begin{array}{c}0.000^{* * *} \\
(0.000)\end{array}$ & $\begin{array}{c}0.000^{* * *} * \\
(0.000)\end{array}$ \\
\hline subject VAR & $\begin{array}{c}0.008^{* * *} * \\
(0.000)\end{array}$ & $\begin{array}{c}0.008^{* * *} \\
(0.000)\end{array}$ & $\begin{array}{c}0.008^{* * *} \\
(0.000)\end{array}$ & $\begin{array}{c}0.009^{* * *} \\
(0.002)\end{array}$ & $\begin{array}{c}0.008^{* * *} \\
(0.000)\end{array}$ & $\begin{array}{c}0.008^{* * *} \\
(0.000)\end{array}$ & $\begin{array}{c}0.008^{* * *} \\
(0.000)\end{array}$ & $\begin{array}{c}0.000 \\
(0.000)\end{array}$ \\
\hline residual VAR & $\begin{array}{c}0.043^{* * *} \\
(0.004)\end{array}$ & $\begin{array}{c}0.041^{* * *} \\
(0.004)\end{array}$ & $\begin{array}{c}0.041^{* * * *} \\
(0.004)\end{array}$ & $\begin{array}{c}0.035^{* * *} \\
(0.005)\end{array}$ & $\begin{array}{c}0.044^{* * *} \\
(0.004)\end{array}$ & $\begin{array}{c}0.043^{* * *} \\
(0.004)\end{array}$ & $\begin{array}{c}0.043^{* * *} \\
(0.004)\end{array}$ & $\begin{array}{c}0.039^{* * *} \\
(0.004)\end{array}$ \\
\hline observations & 17629 & 17629 & 17629 & 17629 & 17605 & 17605 & 17605 & 17605 \\
\hline countries & 30 & 30 & 30 & 30 & 30 & 30 & 30 & $\begin{array}{c}30 \\
1661871\end{array}$ \\
\hline log-likelihood & 1535.487 & 1968.557 & 1980.767 & 2372.240 & 1426.181 & 1557.752 & 1557.908 & 1661.871 \\
\hline
\end{tabular}

Model I adds the most basic characteristic of the decision problem-the probability of winning the prize. This probability shows a positive effect for both gains and losses, indicating a-insensitivity, whereby ambiguity aversion (seeking) increases in probabilities

\footnotetext{
${ }^{5}$ The proportion of variance occurring at the residual level is influenced by our decision to analyse gains and losses separately. Given the large heterogeneity between domains, the variance at the residual level increases to $95 \%$ when we enter both domains jointly into the regressions. The subsequent analysis, however, does not change in any substantive way by treating the two decision domains separately.
} 
for gains (losses). The effect is weaker for losses than it is for gains, further confirming the effects already discussed at the country level. The proportion of variance explained by this variable is, however, rather modest, amounting to $4.7 \%$ of the overall residual variance for gains and only $2.3 \%$ for losses. Model II further adds a dummy indicating whether the probability is larger than 0.5. This is motivated by the jump observed in figure 3, and performs better than for instance inserting the square of the probability. Inserting this dummy constitutes a significant improvement in terms of goodness of fit relative to model I for gains $\left(\chi^{2}(1)=24.42, p<0.001\right.$; likelihood ratio test), but not for losses $\left(\chi^{2}(1)=0.38, p=0.578\right)$. The improvement in terms of variance explained remains, however, quite modest, with a mere $0.2 \%$ of the variance explained relative to model I for gains (and no improvement for losses).

Model III further adds random slopes to our model. That is, we let the effect of probabilities and of the $p>0.5$ dummy be different from subject to subject (i.e., we insert the random slopes at the next higher level, while keeping the random intercept model at the country level). For gains, we find significant variance to be captured both by the probability and the probability cutoff dummy, resulting in a significant improvement of fit relative to model II $\left(\chi^{2}(2)=782.95, p<0.001\right)$. We can explain $14 \%$ of the variance remaining unexplained in model II, which brings us to $19 \%$ of the overall residual variance being explained by prospect characteristics. For losses the picture is similar, albeit somewhat more muted. While there is a clear improvement in model fit $\left(\chi^{2}(2)=\right.$ 207.93, $p<0.001$ ), no significant variance is explained by the random slope for probability. There is, however, significant variance being explained by the individual level random slope of the cutoff dummy. The variance explained improves by $8.9 \%$ relative to model II, which brings us to $10.5 \%$ relative to the overall residual variance. 
The regressions just discussed show that choices are systematically related to prospect characteristics. The relatively large improvement between model II and model III, where we allowed reactions to probabilities to differ between subjects, further shows that there is considerable individual heterogeneity in reactions to prospect characteristics. Nonetheless, our success in explaining overall variance is modest, with $81 \%$ of the residual variance at the premium level remaining unexplained in our best-performing model III for gains, and fully $89.5 \%$ for losses. We can put this figure into context by comparing it to the same figure for risk, obtained by running the exact same models directly on the normalised certainty equivalent for risk, $c e_{i s}^{r}$. The equivalent of model I above for risk, using probability alone to explain choices and assuming uniform effects across subjects, can explain $58 \%$ of the residual variance for gains. For losses, the figure is $61 \%$. Further adding probability squared (which for risk works better than the cutoff dummy) and allowing for random effects to emulate model III, we manage to explain $73 \%$ of the total residual variance for gains, and $75 \%$ for losses (i.e. only $25-27 \%$ of the residual variance remains unexplained).

The large level of residual variance that remains unexplained by prospect characteristics for ambiguity is particularly surprising in the light of the observation that no other prospect characteristics exist that one could conceivably control for (given that other nonlinear elements we tried did not show any effect). We thus conclude from this that the largest part of the variance - indeed around $80 \%$ for gains and $90 \%$ for losses — would appear to consist of pure noise (defined as inconsistency of behaviour with our modelling assumptions). We next explore to what extent we can uncover more stable patterns once we take the analysis to higher levels of analysis and aggregate across the single choices. 


\subsection{Explaining individual variance}

We next try to explain the variance at the individual level. Table 3 shows a number of regressions on individual characteristics. All regressions also control for the prime characteristics at the premium level - the probability of winning, and the probability cutoff dummy at 0.5 . The proportion of the overall variance occurring at the individual level is highly significant, and constitutes $17.6 \%$ for the overall variance for gains, and $15.8 \%$ for losses. ${ }^{6}$

Model I regresses the ambiguity premium on biological characteristics, including a female dummy and the age of the respondent (entered as a z-score), and on study characteristics, including the (z-score of) grade point average (GPA) and a series of dummies capturing the study major. We find women to be more ambiguity averse than men for gains. This corresponds to the findings of Powell and Ansic (1997), while Borghans et al. (2009) and Dimmock et al. (2015b) found an effect going in the opposite direction, and Dimmock et al. (2015a) found no gender effect. There is no gender effect for losses. We also register some effects of study characteristics, but none of them are consistent between gains and losses. For gains, we find arts students to be less ambiguity averse, while medicine students are more ambiguity averse (marginally significant). For losses, we find a correlation indicating that students with a higher GPA tend to be more ambiguity averse - contrary to what one might expect if ambiguity aversion is taken to be a decision bias. The regression performs poorly in terms of the variance explained. For gains, Model I explains 1\% of the variance in the benchmark model, an improvement that

\footnotetext{
${ }^{6}$ These figures obtain after controlling for the prospect caracteristics of the probability of winning and the probability cutoff at $p=0.5$. The proportion of variance occurring at the individual level without the inclusion of these controls is somewhat lower, coming to $16 \%$ for gains and $15.4 \%$ for losses. We take the model including the prospect characteristics as our benchmark model, since we later need those characteristics when inserting crossed effects, and this could result in explained variance decreasing (i.e., the proportion of remaining variance increasing) relative to the benchmark model if it were not to include those characteristics because of the decrease in residual variance.
} 
is only marginally significant $\left(\chi^{2}(10)=17.33, p=0.067\right)$. For losses, the improvement is significant $\left(\chi^{2}(10)=21.11, p=0.020\right)$, but at $1.3 \%$ the proportion of variance explained remains underwhelming.

Table 3: Individual level regressions

\begin{tabular}{|c|c|c|c|c|c|c|c|c|}
\hline & \multicolumn{4}{|c|}{ gains (ambiguity aversion) } & \multicolumn{4}{|c|}{ losses (ambiguity seeking) } \\
\hline & model I & model II & model III & model IV & model I & model II & model III & model IV \\
\hline \multirow[t]{2}{*}{ female } & $0.010^{* *}$ & $0.008^{*}$ & $0.020^{* *}$ & $0.021^{* * *}$ & -0.005 & -0.004 & 0.015 & 0.013 \\
\hline & $(0.004)$ & $(0.005)$ & $(0.008)$ & $(0.008)$ & $(0.005)$ & $(0.004)$ & $(0.011)$ & $(0.010)$ \\
\hline \multirow{2}{*}{ age } & 0.003 & 0.003 & 0.005 & 0.006 & 0.005 & 0.005 & 0.007 & 0.008 \\
\hline & $(0.004)$ & $(0.004)$ & $(0.008)$ & $(0.007)$ & $(0.004)$ & $(0.004)$ & $(0.006)$ & $(0.005)$ \\
\hline \multirow[t]{2}{*}{ GPA } & 0.002 & 0.002 & 0.001 & 0.001 & $-0.008^{* * *}$ & $-0.008^{* * *}$ & $-0.009^{* *}$ & $-0.009^{* *}$ \\
\hline & $(0.002)$ & $(0.002)$ & $(0.004)$ & $(0.004)$ & $(0.002)$ & $(0.002)$ & $(0.004)$ & $(0.004)$ \\
\hline \multirow[t]{2}{*}{ mathematics } & 0.004 & 0.004 & -0.014 & -0.012 & 0.001 & 0.001 & -0.016 & -0.018 \\
\hline & $(0.010)$ & $(0.011)$ & $(0.013)$ & $(0.014)$ & $(0.008)$ & $(0.008)$ & $(0.015)$ & $(0.014)$ \\
\hline \multirow[t]{2}{*}{ natural sciences } & -0.010 & -0.010 & 0.014 & 0.013 & 0.015 & 0.015 & $0.053^{*}$ & $0.048^{*}$ \\
\hline & $(0.008)$ & $(0.008)$ & $(0.016)$ & $(0.016)$ & $(0.011)$ & $(0.011)$ & $(0.027)$ & $(0.025)$ \\
\hline \multirow{2}{*}{ medicine } & $0.019^{*}$ & $0.019^{*}$ & $-0.041^{* *}$ & $-0.041^{* *}$ & 0.002 & 0.003 & -0.016 & -0.017 \\
\hline & $(0.012)$ & $(0.011)$ & $(0.020)$ & $(0.020)$ & $(0.013)$ & $(0.013)$ & $(0.042)$ & $(0.042)$ \\
\hline \multirow[t]{2}{*}{ social sciences } & -0.010 & -0.011 & 0.008 & 0.007 & 0.010 & 0.011 & 0.027 & 0.025 \\
\hline & $(0.009)$ & $(0.010)$ & $(0.020)$ & $(0.020)$ & $(0.010)$ & $(0.010)$ & $(0.020)$ & $(0.020)$ \\
\hline \multirow[t]{2}{*}{ humanities } & -0.006 & -0.007 & 0.013 & 0.013 & -0.011 & -0.011 & 0.007 & 0.003 \\
\hline & $(0.012)$ & $(0.012)$ & $(0.027)$ & $(0.027)$ & $(0.018)$ & $(0.019)$ & $(0.022)$ & $(0.021)$ \\
\hline \multirow[t]{2}{*}{ arts } & $-0.028^{* *}$ & $-0.027^{* *}$ & $0.033^{*}$ & $0.041^{*}$ & 0.002 & 0.002 & $0.056^{* *}$ & $0.044^{* *}$ \\
\hline & $(0.013)$ & $(0.013)$ & $(0.019)$ & $(0.021)$ & $(0.019)$ & $(0.019)$ & $(0.022)$ & $(0.022)$ \\
\hline \multirow[t]{2}{*}{ study other } & $-0.014^{*}$ & $-0.014^{*}$ & $-0.016^{*}$ & $-0.016^{*}$ & 0.001 & 0.002 & 0.003 & 0.001 \\
\hline & $(0.008)$ & $(0.008)$ & $(0.008)$ & $(0.008)$ & $(0.008)$ & $(0.008)$ & $(0.007)$ & $(0.007)$ \\
\hline \multirow[t]{2}{*}{ power distance } & & -0.001 & -0.001 & -0.001 & & 0.001 & $0.003^{*}$ & $0.003^{*}$ \\
\hline & & $(0.001)$ & $(0.002)$ & $(0.002)$ & & $(0.001)$ & $(0.001)$ & $(0.001)$ \\
\hline \multirow[t]{2}{*}{ individualism } & & $0.001^{*}$ & 0.000 & 0.000 & & 0.000 & 0.001 & 0.001 \\
\hline & & $(0.001)$ & $(0.001)$ & $(0.001)$ & & $(0.001)$ & $(0.002)$ & $(0.002)$ \\
\hline \multirow[t]{2}{*}{ uncertainty avoid. } & & -0.000 & $0.002^{*}$ & $0.002^{*}$ & & 0.000 & 0.002 & 0.003 \\
\hline & & $(0.001)$ & $(0.001)$ & $(0.001)$ & & $(0.001)$ & $(0.002)$ & $(0.002)$ \\
\hline \multirow[t]{2}{*}{ masculinity } & & -0.000 & $0.005^{* * *}$ & $0.005^{* * *}$ & & 0.000 & 0.001 & 0.001 \\
\hline & & $(0.001)$ & $(0.001)$ & $(0.001)$ & & $(0.001)$ & $(0.001)$ & $(0.001)$ \\
\hline \multirow[t]{2}{*}{ female* prob. } & & & -0.024 & -0.023 & & & $-0.038^{* *}$ & $-0.038^{* *}$ \\
\hline & & & $(0.017)$ & $(0.017)$ & & & $(0.017)$ & $(0.017)$ \\
\hline natural*prob. & & & $-0.047^{*}$ & $-0.047^{*}$ & & & -0.076 & -0.077 \\
\hline & & & $(0.026)$ & $(0.026)$ & & & $(0.048)$ & $(0.048)$ \\
\hline medicine* prob. & & & $0.121^{* * *}$ & $0.121^{* * *}$ & & & 0.038 & 0.038 \\
\hline & & & $(0.045)$ & $(0.045)$ & & & $(0.063)$ & $(0.063)$ \\
\hline arts*prob. & & & $-0.121^{* * *}$ & $-0.121^{* * *}$ & & & $-0.108^{* * *}$ & $-0.108^{* * *}$ \\
\hline & & & $(0.041)$ & $(0.041)$ & & & $(0.031)$ & $(0.031)$ \\
\hline other*prob. & & & $0.255^{* * *}$ & $0.270^{* * *}$ & & & $-0.176^{* * *}$ & $-0.181 * * *$ \\
\hline & & & $(0.015)$ & $(0.014)$ & & & $(0.010)$ & $(0.009)$ \\
\hline power*prob. & & & -0.000 & -0.000 & & & $-0.004^{*}$ & $-0.004^{*}$ \\
\hline & & & $(0.004)$ & $(0.004)$ & & & $(0.002)$ & $(0.002)$ \\
\hline mascul.*prob. & & & $-0.010^{* * *}$ & $-0.010 * * *$ & & & -0.002 & -0.002 \\
\hline & & & $(0.003)$ & $(0.003)$ & & & $(0.002)$ & $(0.002)$ \\
\hline prospect char. & $\checkmark$ & $\checkmark$ & $\checkmark$ & $\checkmark$ & $\checkmark$ & $\checkmark$ & $\checkmark$ & $\checkmark$ \\
\hline random slopes & & & & $\checkmark$ & & & & $\checkmark$ \\
\hline constant & $\begin{array}{c}0.012 \\
(0.008)\end{array}$ & $\begin{array}{c}0.061^{* * *} \\
(0.007)\end{array}$ & $\begin{array}{c}0.061^{* * *} \\
(0.007)\end{array}$ & $\begin{array}{c}0.061^{* * *} \\
(0.008)\end{array}$ & $\begin{array}{c}-0.079^{* * *} \\
(0.010)\end{array}$ & $\begin{array}{c}-0.079^{* * *} \\
(0.009)\end{array}$ & $\begin{array}{c}-0.036^{* * *} \\
(0.006)\end{array}$ & $\begin{array}{c}-0.032^{* * * *} \\
(0.006)\end{array}$ \\
\hline country VAR & $\begin{array}{c}0.000^{* * *} \\
(0.000)\end{array}$ & $\begin{array}{c}0.000 * * * \\
(0.000)\end{array}$ & $\begin{array}{c}0.000^{* * *} * \\
(0.000)\end{array}$ & $\begin{array}{c}0.000^{* * *} * \\
(0.000)\end{array}$ & $\begin{array}{c}0.000^{* * *} \\
(0.000)\end{array}$ & $\begin{array}{c}0.000 * * * \\
(0.000)\end{array}$ & $\begin{array}{c}0.000^{* * *} \\
(0.000)\end{array}$ & $\begin{array}{c}0.000^{* * *} \\
(0.000)\end{array}$ \\
\hline individual VAR & $0.008^{* * *}$ & $0.008^{* * *}$ & $0.008^{* * *}$ & $0.008^{* * *}$ & $0.008^{* * *}$ & $0.008^{* * *}$ & $0.008^{* * *}$ & $0.007^{* * *}$ \\
\hline & $(0.000)$ & $(0.000)$ & $(0.000)$ & $(0.000)$ & $(0.000)$ & $(0.000)$ & $(0.000)$ & $(0.000)$ \\
\hline residual VAR & $0.041^{* * *}$ & $0.041 * * *$ & $0.040^{* * *}$ & $0.040^{* * *}$ & $0.043^{* * *}$ & $0.043^{* * *}$ & $0.043^{* * *}$ & $0.043^{* * *}$ \\
\hline & $(0.004)$ & $(0.004)$ & $(0.004)$ & $(0.004)$ & $(0.004)$ & $(0.004)$ & $(0.004)$ & $(0.004)$ \\
\hline Observations & 17629 & 17629 & 17629 & 17629 & 17605 & 17605 & 17605 & 17605 \\
\hline Subjects & 2939 & 2939 & 2939 & 2939 & 2939 & 2939 & 2939 & 2939 \\
\hline Countries & 30 & 30 & 30 & 30 & 30 & 30 & 30 & 30 \\
\hline log likelihood & 1989.434 & 1991.725 & 2051.410 & 2057.241 & 1568.462 & 1568.961 & 1602.948 & 1612.540 \\
\hline
\end{tabular}

Model II further adds responses to a questionnaire eliciting cultural attitudes devel- 
oped by Hofstede (1980). The cultural attitudes are then grouped into four dimension or attitudes - individualism, uncertainty avoidance, masculinity, and power distance - amongst which especially uncertainty avoidance has been indicated to capture something akin to ambiguity aversion (see also Rieger, Wang and Hens, 2014, for correlations with risk aversion). For gains, we observe a marginally significant positive correlation between individualism and ambiguity aversion, while we observe no significant correlations with losses. The model does not represent a significant improvement over model I either for gains $\left(\chi^{2}(4)=4.58, p=0.333\right)$ or for losses $\left(\chi^{2}(4)=1.00, p=0.910\right)$. Using aggregate country-level measures of the Hofstede measures jointly with individual deviations instead of the individual measures used here does not improve these results.

Model III adds interaction effects to model II. That is, all individual-level variables included in model II are crossed with the probability of winning. This allows us not only to investigate average ambiguity attitudes at the individual level as done previously, but also whether a-insensitivity varies with subject characteristics. The probability is always recentered to make $p=0.5$ coincide with zero, so as to facilitate the interpretation of the pure effects. This model constitutes a significant improvement over model II both for gains $\left(\chi^{2}(14)=119.37, p<0.001\right)$ and for losses $\left(\chi^{2}(14)=67.97, p<0.001\right)$. Some interesting effects emerge (we only show significant interactions in the table to keep it tractable). For gains, we now find medicine students to be less ambiguity averse than economics students, a correlation between a high score on masculinity and ambiguity aversion, and a marginally significant positive correlation between uncertainty avoidance and ambiguity aversion (individualism is no longer significant). These effects are balanced by effects on a-insensitivity, with medicine students being considerably more a-insensitive compared to economics students, and masculinity being associated with slightly reduced 
a-insensitivity. Once again, however, these effects are not reproduced for losses, where some other effects emerge, such as women being less a-insensitive than men and arts students being both more ambiguity averse than economics students and less a-insensitive.

Finally, model IV allows for random slopes at the country level for some basic characteristics (biological and study characteristics). This further improves the fit relative to model III for both gains $\left(\chi^{2}(4)=11.66, p=0.020\right)$ and losses $\left(\chi^{2}(4)=19.18, p<0.001\right)$. More interesting, however, is to determine to what extent we have succeeded in explaining the individual level variance. For gains, model IV explains about $2.7 \%$ of the individual level variance. For losses, the figure is $3.6 \%$. These figures look low even compared to the low standards for risk preferences, where large unexplained heterogeneity at the individual level is the norm (von Gaudecker et al., 2011). Although they reach similar conclusions, L'Haridon and Vieider (2016) found several explanatory variables to be significant at the individual level, and remarkable consistency in these effects between gains and losses. It is also informative to once again consider the interclass correlation coefficient $(I C C)$ at the individual level. ${ }^{7}$ For ambiguity, we found it to be in the range of $0.15-0.18$, indicating that any two randomly chosen choices from one randomly chosen individual would have a correlation of $0.15-0.18$. For risk, the equivalent range is $0.38-0.40$ - still far from perfect, but a clear improvement over the figure for ambiguity.

We can but conclude this section in a similar vein as for the premium level section above. While we can account for some heterogeneity in the data at the individual level recurring to observable characteristics of the decision makers, the proportion of variance thus explained is low both in absolute terms, as well as in comparison to results for risk preferences.

\footnotetext{
${ }^{7}$ The ICC is defined as the proportion of overall variance captured at the individual level. Let $\sigma_{n}$ be the variance at the individual level in a model empty of covariates, and let $\sigma_{c}$ be the country level variance and $\sigma_{\rho}$ the residual varaince. We then have $I C C_{n}=\frac{\sigma_{n}}{\sigma_{n}+\sigma_{c}+\sigma_{\rho}}$.
} 


\subsection{Explaining country-level variance}

We once again start by quantifying the variance occurring at this level, based on the benchmark model, which in this case comprises both prospect characteristics as above and some basic individual characteristics (sex, age, and GPA). We find the ICC to be very low at $0.8 \%$ for both gains and losses. ${ }^{8}$ This is, however, a relative figure, rendered artificially low by the massive amount of residual variance discussed above. Indeed, we have seen in the descriptive country comparison at the beginning of the results section that countries do significantly differ in terms of their ambiguity attitudes (as is also apparent from the high statistical significance of the variance at the country level).$^{9}$ It thus seems well worth our while to try and account for this variance by the use of country-level indicators. Prime candidates for such indicators are economic, geographical, and institutional variables as used in the macroeconomic literature on comparative development and growth. Once again, we mainly focus on the extent to which we can explain the between-country variance.

Table 4 shows the regression results. The benchmark model again serves to quantify the variance occurring at this level, which we show multiplied by 1000 in the table to be able to discern changes across regressions. Model I introduces income and institutional variables. The income variables include GDP per capita (in PPP and taking logs;

\footnotetext{
8 These figures are also low compared to previous results obtained for risk preferences. Using risk data from this same data set, L'Haridon and Vieider (2016) reported considerably more heterogeneity between individuals than between countries, with the country-level variance quantified at between $7 \%$ and $33 \%$ depending on the model parameter. Using a hypothetical question obtained from representative samples from 76 countries and 80,000 respondents, Falk, Becker, Dohmen, Enke, Huffman and Sunde (2015) found the country level variance to be $9 \%$. Using a different survey question in a sample of over 100,000 repondents from 78 countries, Bouchouicha and Vieider (2017) found this figure to be $10 \%$.

${ }^{9}$ It seems desirable to obtain a measure of between-country variation that is independent of the level of variance at the residual level. A very simple measure consists in pairwise between-country comparisons of average ambiguity premia aggregated per subject for gains and losses. Of all possible comparisons, $88 \%$ are significant for gains and $89 \%$ for losses (at the $5 \%$ level, without adjustment for multiple testing). The corresponding result is somewhat lower for risk, coming in at $72 \%$ for gains and $75 \%$ for losses. This shows that there is indeed substantial between-country variation of ambiguity attitudes.
} 
Table 4: Country level regressions

\begin{tabular}{|c|c|c|c|c|c|c|c|c|}
\hline & \multicolumn{4}{|c|}{ gains (ambiguity aversion) } & \multicolumn{4}{|c|}{ losses (ambiguity seeking) } \\
\hline & benchmark & model I & model II & model III & benchmark & model I & model II & model III \\
\hline log GDP p.c. & & $\begin{array}{c}0.010^{* *} \\
(0.005)\end{array}$ & $\begin{array}{c}0.024^{* * *} \\
(0.009)\end{array}$ & $\begin{array}{c}0.023^{* * * *} \\
(0.009)\end{array}$ & & $\begin{array}{c}0.005 \\
(0.006)\end{array}$ & $\begin{array}{c}-0.003 \\
(0.007)\end{array}$ & $\begin{array}{c}-0.003 \\
(0.007)\end{array}$ \\
\hline prob. *GDP & & & & $\begin{array}{c}0.057^{* * *} \\
(0.014)\end{array}$ & & & & $\begin{array}{c}0.042^{* *} \\
(0.019)\end{array}$ \\
\hline Gini coeff. & & $\begin{array}{c}0.003 \\
(0.004)\end{array}$ & $\begin{array}{c}0.003 \\
(0.004)\end{array}$ & $\begin{array}{c}0.003 \\
(0.004)\end{array}$ & & $\begin{array}{c}-0.008^{* *} \\
(0.003)\end{array}$ & $\begin{array}{c}-0.006^{* *} \\
(0.003)\end{array}$ & $\begin{array}{c}-0.006^{* *} \\
(0.003)\end{array}$ \\
\hline private university & & $\begin{array}{c}0.019 \\
(0.013)\end{array}$ & $\begin{array}{c}0.011 \\
(0.013)\end{array}$ & $\begin{array}{c}0.011 \\
(0.013)\end{array}$ & & $\begin{array}{c}-0.019^{*} \\
(0.011)\end{array}$ & $\begin{array}{c}-0.014 \\
(0.011)\end{array}$ & $\begin{array}{c}-0.014 \\
(0.011)\end{array}$ \\
\hline democracy & & $\begin{array}{c}0.001 \\
(0.001)\end{array}$ & $\begin{array}{l}-0.001 \\
(0.001)\end{array}$ & $\begin{array}{l}-0.001 \\
(0.001)\end{array}$ & & $\begin{array}{c}-0.003^{*} \\
(0.002)\end{array}$ & $\begin{array}{l}-0.002 \\
(0.002)\end{array}$ & $\begin{array}{l}-0.002 \\
(0.002)\end{array}$ \\
\hline British legal origins & & $\begin{array}{c}-0.021^{*} \\
(0.011)\end{array}$ & $\begin{array}{l}-0.002 \\
(0.009)\end{array}$ & $\begin{array}{l}-0.002 \\
(0.009)\end{array}$ & & $\begin{array}{c}0.006 \\
(0.009)\end{array}$ & $\begin{array}{c}0.002 \\
(0.008)\end{array}$ & $\begin{array}{c}0.002 \\
(0.008)\end{array}$ \\
\hline Socialist legal origins & & $\begin{array}{l}-0.006 \\
(0.010)\end{array}$ & $\begin{array}{c}0.007 \\
(0.009)\end{array}$ & $\begin{array}{c}0.007 \\
(0.009)\end{array}$ & & $\begin{array}{c}-0.030^{* *} \\
(0.014)\end{array}$ & $\begin{array}{c}-0.033^{* * *} \\
(0.013)\end{array}$ & $\begin{array}{c}-0.033^{* * *} \\
(0.013)\end{array}$ \\
\hline German legal origins & & $\begin{array}{c}-0.022^{* * *} * \\
(0.008)\end{array}$ & $\begin{array}{l}-0.009 \\
(0.007)\end{array}$ & $\begin{array}{l}-0.009 \\
(0.007)\end{array}$ & & $\begin{array}{l}-0.007 \\
(0.010)\end{array}$ & $\begin{array}{l}-0.009 \\
(0.010)\end{array}$ & $\begin{array}{l}-0.009 \\
(0.010)\end{array}$ \\
\hline OPEC dummy & & & $\begin{array}{c}-0.057^{* *} \\
(0.022)\end{array}$ & $\begin{array}{c}-0.057^{* *} \\
(0.022)\end{array}$ & & & $\begin{array}{c}0.025 \\
(0.020)\end{array}$ & $\begin{array}{c}0.025 \\
(0.020)\end{array}$ \\
\hline pred. genetic div. & & & $\begin{array}{c}-0.342^{* * *} \\
(0.111)\end{array}$ & $\begin{array}{c}-0.342^{* * *} \\
(0.111)\end{array}$ & & & $\begin{array}{c}0.030 \\
(0.127)\end{array}$ & $\begin{array}{c}0.030 \\
(0.127)\end{array}$ \\
\hline pr. gen. div. sqrd & & & $\begin{array}{c}0.350^{* * *} \\
(0.112)\end{array}$ & $\begin{array}{c}0.350^{* * *} \\
(0.112)\end{array}$ & & & $\begin{array}{l}-0.034 \\
(0.125)\end{array}$ & $\begin{array}{l}-0.034 \\
(0.125)\end{array}$ \\
\hline degrees latitude & & & $\begin{array}{c}-0.001^{*} \\
(0.000)\end{array}$ & $\begin{array}{c}-0.001^{*} \\
(0.000)\end{array}$ & & & $\begin{array}{l}0.001^{*} \\
(0.000)\end{array}$ & $\begin{array}{l}0.001 * \\
(0.000)\end{array}$ \\
\hline probability | country r.s. & & & & $\checkmark$ & & & & $\checkmark$ \\
\hline prospect controls & $\checkmark$ & $\checkmark$ & $\checkmark$ & $\checkmark$ & $\checkmark$ & $\checkmark$ & $\checkmark$ & $\checkmark$ \\
\hline individual controls & $\checkmark$ & $\checkmark$ & $\checkmark$ & $\checkmark$ & $\checkmark$ & $\checkmark$ & $\checkmark$ & $\checkmark$ \\
\hline constant & $\begin{array}{c}0.059^{* * *} \\
(0.005)\end{array}$ & $\begin{array}{c}-0.031 \\
(0.048) \\
\end{array}$ & $\begin{array}{c}-0.127^{*} \\
(0.065) \\
\end{array}$ & $\begin{array}{c}-0.127^{*} \\
(0.065) \\
\end{array}$ & $\begin{array}{c}-0.034^{* * *} \\
(0.005) \\
\end{array}$ & $\begin{array}{c}-0.062 \\
(0.046) \\
\end{array}$ & $\begin{array}{c}-0.007 \\
(0.049) \\
\end{array}$ & $\begin{array}{l}-0.007 \\
(0.049) \\
\end{array}$ \\
\hline country VAR $(\times 1000)$ & $\begin{array}{c}0.401^{* * *} \\
(0.201)\end{array}$ & $\begin{array}{c}0.0202^{* * *} \\
(0.102)\end{array}$ & $\begin{array}{c}0.061^{* * *} \\
(0.048)\end{array}$ & $\begin{array}{c}0.061^{* * *} \\
(0.048)\end{array}$ & $\begin{array}{c}0.394^{* * *} \\
(0.241)\end{array}$ & $\begin{array}{c}0.252^{* * *} \\
(0.148)\end{array}$ & $\begin{array}{c}0.217^{* * *} \\
(0.139)\end{array}$ & $\begin{array}{c}0.217^{* * *} \\
(0.139)\end{array}$ \\
\hline subject VAR & $\begin{array}{c}0.008^{* * *} \\
(0.000)\end{array}$ & $\begin{array}{c}0.008^{* * *} \\
(0.000)\end{array}$ & $\begin{array}{c}0.008^{* * *} \\
(0.000)\end{array}$ & $\begin{array}{c}0.008^{* * *} \\
(0.000)\end{array}$ & $\begin{array}{c}0.008^{* * *} \\
(0.000)\end{array}$ & $\begin{array}{c}0.008^{* * *} \\
(0.000)\end{array}$ & $\begin{array}{c}0.008^{* * *} \\
(0.000)\end{array}$ & $\begin{array}{c}0.008^{* * *} \\
(0.000)\end{array}$ \\
\hline residual VAR & $\begin{array}{c}0.041^{* * *} \\
(0.004)\end{array}$ & $\begin{array}{c}0.041^{* * *} \\
(0.004)\end{array}$ & $\begin{array}{c}0.041^{* * *} \\
(0.004)\end{array}$ & $\begin{array}{c}0.040^{* * *} \\
(0.004)\end{array}$ & $\begin{array}{c}0.043^{* * *} \\
(0.004)\end{array}$ & $\begin{array}{c}0.043^{* * *} \\
(0.004)\end{array}$ & $\begin{array}{c}0.043^{* * *} \\
(0.004)\end{array}$ & $\begin{array}{c}0.043^{* * * *} \\
(0.004)\end{array}$ \\
\hline Observations & 17629 & 17629 & 17629 & 17629 & 17605 & 17605 & 17605 & 17605 \\
\hline Subjects & 2939 & 2939 & 2939 & 2939 & 2939 & 2939 & 2939 & 2939 \\
\hline countries & 30 & 30 & 30 & 30 & 30 & 30 & 30 & 30 \\
\hline log likelihood & 1983.099 & 1989.931 & 1995.732 & 2099.960 & 1565.737 & 1570.417 & 1571.647 & 1648.301 \\
\hline
\end{tabular}

World Bank data for 2010), as well as the Gini coefficient to capture income inequality (assembled from various sources - see appendix A), and a dummy capturing whether the university where the experiment was run was private (which is likely to indicate students that are well off relative to the rest of the country). The institutional data comprise 'democracy', a variable capturing the institutional and political stability over the last decades, and legal origins dummies (La Porta, Lopez-De-Silanes, Shleifer and Vishny, 1997). The regression explains a marginally significant proportion of the variance for gains $\left(\chi^{2}(7)=13.66, p=0.058\right)^{10}$, but not for losses $\left(\chi^{2}(7)=9.36, p=0.228\right)$. For gains,

\footnotetext{
${ }^{10}$ Given the highly significant correlations with especially GDP, it may appear odd that the improvement in variance explained is only marginally significant. This is in part due to the penalty imposed
} 
we find a significant effect of GDP per capita, going in the direction of richer countries being more ambiguity averse. We also find some effects of legal origins, with subjects in countries with UK legal origins and socialist legal origins showing less ambiguity aversion than subjects in French legal origins countries. For losses, we find subjects from countries with more income inequality to be more ambiguity averse; we also find marginally significant effects of democracy (more institutionally stable countries are more ambiguity averse). We also find more ambiguity aversion in private universities, and socialist legal origins countries are more ambiguity averse for losses.

Model II further adds variables capturing genetic diversity and a geographical control. The former contain a measure of predicted genetic diversity developed by Ashraf and Galor (2013), and its square. Similar measures were used by Spolaore and Wacziarg (2009) to explain income differences deriving from trading behaviour. Becker, Dohmen, Enke and Falk (2015) found correlations of such genetic measurements with risk preferences, explaining the correlations by a 'serial founder effect'. The geographical variable consists of absolute distance from the equator (in degrees of latitude). For gains, these variables further reinforce the effect of GDP. Subjects in OPEC countries are found to be less ambiguity averse than what their GDP would suggest. Genetic diversity shows an inverse U-shape, whereby moderately diverse countries (typically in Europe) are the least ambiguity averse (after controlling for the other variables, including GDP), and the most diverse countries in Africa and least diverse ones in Latin America and East Asia are the most ambiguity averse. This is interesting, because this parallels the relationship between genetic diversity and GDP per capita pointed out by Ashraf and Galor (2013). We are, however, unable to replicate these effects for losses. Once again, the model sigfor using up several degrees of freedom. Indeed, if we only add GDP per capita in the regression, the proportion of variance explained is significant at conventional levels $\left(\chi^{2}(1)=5.29, p=0.022\right)$. 
nificantly improves the fit over model I for gains $\left(\chi^{2}(3)=11.60, p=0.021\right)$, but not for $\operatorname{losses}\left(\chi^{2}(3)=2.46, p=0.652\right)$.

Finally, in model III we add the random slopes of the prospect characteristics to account for differences across countries. In addition, we try to explain difference in a-insensitivity across countries by adding an interaction with GDP per capita to the fixed part of the model. This again significantly improves model fit - this time for both gains $\left(\chi^{2}(2)=208.46, p<0.001\right)$ and for losses $\left(\chi^{2}(2)=153.31, p<0.001\right)$. The effects previously found remain generally stable. The interaction term (or 'crossed effect') between GDP per capita and probability furthermore shows that a-insensitivity is larger in our subject pool for richer countries - an effect that holds for both gains and losses.

We conclude this section by assessing the success of our modelling exercise. Overall, our heaviest model III explains fully $85 \%$ of the between country variance for gains, and a somewhat more modest $45 \%$ for losses. The results are thus qualitatively different from those seen at lower levels. Indeed, the proportion of variance explained is higher even than for risk, albeit similar in the sense that aggregated preferences prove easier to explain than preferences at the individual level. One explanation for this may be the lower total variance to be explained. Another may lie in the sheer number of macroeconomic characteristics to pick from. Ultimately, however, we believe that aggregating ambiguity preferences at this level achieves something very important that could not be achieved at lower levels - the emergence of stable trends from a sea of heterogeneity.

\section{Discussion and conclusion}

We found our measures of ambiguity aversion to reproduce typical aggregate trends observed in previous experiments. Aggregating across different prospects and across indi- 
viduals, we found ambiguity aversion to be the prevalent pattern for gains in all countries. For losses, we still found a prevalence of ambiguity aversion in the aggregate. This ambiguity aversion was, however, much weaker than for gains, and for some countries ambiguity neutrality could not be rejected (with one country being significantly ambiguity seeking). We furthermore replicated patterns whereby ambiguity attitudes change less than proportionally with the probability, known as a-insensitivity, in nearly all countries, and for both gains and losses. We did, however, not find significant levels of ambiguity seeking for either losses or small probabilities, as have been reported in most of the previous literature (see Trautmann and van de Kuilen, 2015, for a review). This may be due to the our measurement tasks, which are not directly comparative in nature, so that they can be seen as a lower bound on ambiguity attitudes.

When it came to explaining the patterns found at the macroeconomic level, our regressions proved quite successful. GDP per capita was significantly related to ambiguity aversion, with poorer countries being significantly less ambiguity averse. This parallels recent findings according to which poorer countries tend to be less risk averse than rich ones (L'Haridon and Vieider, 2016; Vieider, Beyene, Bluffstone, Dissanayake, Gebreegziabher, Martinsson and Mekonnen, 2016). We further found an inverse-U shaped effect of predicted genetic diversity. This effect seems interesting in conjunction with a similarlyshaped relationship between the same genetic diversity measure and GDP uncovered by Ashraf and Galor (2013). Indeed, there may be wider implications considering the link of genetic measures to trade (Spolaore and Wacziarg, 2009), and the complementary relationship between unfamiliarity and trade (Huang, 2007). It seems, however, premature to overemphasize this point based on one single dataset.

Once we move from the group level to the individual and premium level, our results 
change. Large amounts of heterogeneity are the preponderant finding at the individual level. We succeed in explaining very little of the individual-level variance. Our attempts show limited success not only in absolute terms, but even compared to similar exercises carried out for risk preferences, which may themselves be considered to have had mixed success. This conclusion is furthermore not unique to our data, since the few previous studies investigating demographic correlates of ambiguity preferences do not seem to have uncovered any regularities either (see the discussion of Trautmann and van de Kuilen, 2015, on this point). Any effects of demographics we find at the individual level are inconsistent between gains and losses, and tend to be economically weak.

The picture becomes even bleaker when moving from the subject level to the premium level. Even after including all conceivable prospect characteristics and allowing those characteristics to have individual-specific effects, we manage to explain a meagre $19 \%$ of the variance at that level for gains, and not much more than $10 \%$ for losses. For risk, the result using similar models (which have not been optimised specifically to account for risk preferences) is close to $75 \%$. In other words, the amount of variance we manage to explain at the premium level is particularly low when compared to similar exercises for risk preferences. There is only one conclusion to be drawn from this - the data are plagued by massive amounts of noise. These findings are consistent with those of Stahl (2014), who also found high levels of noise in measures of ambiguity aversion.

Our results can shed some light on the many unsuccessful attempts at detecting stable correlates of ambiguity preferences at the individual level. Borghans et al. (2009), Binmore et al. (2012), and Sutter et al. (2013) all express some frustration in detecting such correlates. Dimmock et al. (2015a) and Dimmock et al. (2015b) report better success at predicting economic outcomes. While their main focus is on correlates of ambiguity 
attitudes, their results are more in agreement with ours than one might infer from the tone of the papers. For instance, in the Dutch sample they find that a comprehensive set of observable characteristics of respondents could account for between $2.2 \%$ and $5.4 \%$ of the variance in the different parameters. In the US population, individual characteristics can explain $2.6 \%$ of the overall variance. ${ }^{11}$ Furthermore, for losses the authors could not find any correlates of ambiguity attitudes except for risk aversion. Overall, our results thus appear to be in line with the bulk of the previous literature when it comes to the detection of correlates of ambiguity attitudes.

This leaves the question of whether these low correlations are due to noise in the data or to heterogeneity that is orthogonal to observable characteristics. While we cannot provide a definite answer to this question, we strongly suspect that noise plays an important role. To see this, consider the correlation of ambiguity premia for $(1 / 8: 20 ; 0)$ and $(1 / 8: 20 ; 5)$ and for $(7 / 8: 20 ; 0)$ and $(7 / 8: 20 ; 5)$. These two tasks are very similar, and can thus be used to examine the test-retest reliability of our measures. The correlation we find between the two is, however, very low at $\rho=0.24$ and $\rho=0.53$ respectively (Spearman rank correlations; results for losses are similar and can be found in the online appendix). Out-of-sample predictions based on parameters estimated from our model perform even more poorly — see online appendix for details. According to classical measurement theory (see e.g. Allen and Yen, 2001), this means that any correlation with observable characteristics would be attenuated significantly due to measurement issues of ambiguity attitudes. This in turn means that noise in measurement is almost certainly a substantial part of the story when it comes to explaining the weak correlations with observable characteristics we and others have observed.

Given the good results at the aggregate level, and given the much more stable trends

\footnotetext{
${ }^{11}$ We are grateful to Roy Kouwenberg for having provided this figure in private correspondence.
} 
uncovered for risk in this same data set (L'Haridon and Vieider, 2016), we think that the high levels of noise are unlikely to result from particular measurement problems affecting only our experiment. Noise may, however, be exacerbated by the separate measurement of valuations for risk and for uncertainty, from which ambiguity attitudes are then derived. The CEs for risk and for uncertainty may be affected by separate error terms, which could increase the incidence of noise. An examination of violations of first order stochastic dominance under risk and uncertainty, however, does not reveal any unusual noisiness in our measurements (see online appendix for details). An interesting question is nevertheless to what extent our particular measurement method may have influenced the noise levels we find, and whether these noise levels are absent in tasks involving direct comparisons between risky and uncertainty tasks, such as matching probabilities.

In particular, Dimmock et al. (2015b) report better success in explaining variations in matching probabilities across the probability spectrum. The difference between the two tasks may, however, be smaller than one might think. Binmore et al. (2012) draw similar conclusions to ours, even though they use matching probabilities to measure ambiguity attitudes. Dimmock et al. (2015b), using two choices as consistency checks, report that fully $42 \%$ of such responses result in inconsistencies. We can compare these findings to our own data by examining the consistency of choices between the premia used in the analysis and premia for prospects with non-zero lower outcomes. Using all four such pairs, we find violation rates between $24 \%$ and $28 \%$ (see online appendix for details). These rates are indeed remarkably consistent with those reported by Dimmock et al. (2015b). While only a direct methodological comparison can give conclusive evidence about the relative merits of different measurement tasks, our tentative conclusion from this evidence is thus that the difference seems to be at best one of degree. For instance, Dimmock et al. 
(2015b) report that $43 \%$ of the within-subject variance can be explained by probability variations. While this is certainly better than our $20 \%$, it still falls far short of the $75 \%$ we observe under risk. ${ }^{12}$ Ultimately, only direct comparative evidence will allow for a clear conclusion on the relative merits of different methods used to measure ambiguity attitudes.

Our conclusions about measuring ambiguity attitudes are rather negative. We do not want to say with this that ambiguity does not matter. The point is rather that processes resembling ambiguity are quite artificial, and may thus have limited real world applications. There furthermore appear to be severe measurement problems. Ambiguity may well matter where it occurs naturally in the real wold - see for instance Kunreuther, Meszaros, Hogarth and Spranca (1995) for evidence that the presence of ambiguity about the precise probabilities underlying a process affects the pricing decisions of insurance underwriters. The way forward may then be to investigate naturally occurring uncertainty, rather than artificial ambiguity that is rare in the real world. This will mean focusing on natural sources of uncertainty, as some studies have already done (Abdellaoui et al., 2011; Baillon, Bleichrodt, Keskin, l'Haridon and Li, 2016a). Baillon et al. (2016b) proposed a method for the nonparametric measurement of ambiguity attitudes and showed that it exhibits high levels of measurement reliability. This may also mean moving away from a comparison point of risk, which can hardly ever be found in reality, and towards varying degrees of ambiguity underlying outcome-generating processes. Time will tell whether such approaches will indeed perform better in terms of the external validity of experimentally measured preferences.

\footnotetext{
${ }^{12}$ The difference between our figure and theirs may further be over-estimated by the different methods we use to account for explained variance. For instance, Dimmock et al. use an 'overall $R^{2}$ ' to account for the explained variance. This captures changes in within- and between-subject variance, while our measure only looks at one type of variance in isolation.
} 


\section{A Characteristics country by country}

Table A.1: Number of subjects per country and principal characteristics

\begin{tabular}{|c|c|c|c|c|c|c|c|c|c|c|c|c|c|c|c|}
\hline country & Sub.s & For.s & age & male & econ & math & natural & hum & arts & social & $\mathrm{PPP} / €$ & language & University & GDP & Gini \\
\hline Australia & 61 & 6 & 25.41 & 0.656 & 0.262 & 0.180 & 0.131 & 0.098 & 0.049 & 0.033 & 2 AUD & English & University of Adelaide & 39,466 & .305 \\
\hline Belgium & 91 & 13 & 20.64 & 0.451 & 0.418 & 0.055 & 0.088 & 0.066 & 0.022 & 0.132 & $€ 1$ & French & University of Liege & 38,633 & .280 \\
\hline Brazil & 84 & 1 & 20.86 & 0.683 & 0.964 & 0.000 & 0.000 & 0.012 & 0.000 & 0.000 & 2 Real & Portuguese & Escola de Administraão, São Paolo & 11,719 & .547 \\
\hline Cambodia & 80 & 0 & 20.74 & 0.375 & 0.000 & 0.212 & 0.237 & 0.125 & 0.175 & 0.175 & 1500 Riel & Khmer & University of Phnom Penh & 2,373 & .444 \\
\hline Chile & 96 & 0 & 21.46 & 0.479 & 0.000 & 0.000 & 0.229 & 0.000 & 0.000 & 0.260 & 500 Pesos & Spanish & Universidad de Conception & 17,125 & .521 \\
\hline China & 204 & 0 & 21.55 & 0.608 & 0.127 & 0.451 & 0.181 & 0.083 & 0.005 & 0.064 & $4 \mathrm{RMB}$ & Chinese & Jiao Tong, Shanghai & 8,442 & .480 \\
\hline Colombia & 128 & 0 & 21.21 & 0.500 & 0.062 & 0.797 & 0.047 & 0.031 & 0.023 & 0.008 & 1500 Pesos & Spanish & Universidad de Medellin & 10,103 & .560 \\
\hline Costa Rica & 106 & 5 & 22.71 & 0.666 & 0.292 & 0.179 & 0.113 & 0.009 & 0.019 & 0.132 & 500 Colones & Spanish & Universidad de Costa Rica, San Jose & 12,236 & .503 \\
\hline Czech Rep. & 99 & 2 & 22.38 & 0.606 & 0.485 & 0.111 & 0.051 & 0.121 & 0.030 & 0.091 & 20 Kronas & Czech & Charles University, Prague & 25,949 & .310 \\
\hline Ethiopia & 140 & 1 & 21.14 & 0.657 & 0.593 & 0.107 & 0.079 & 0.021 & 0.000 & 0.093 & 6 Birr & English & Addis Ababa University & 1,116 & .300 \\
\hline France & 93 & 8 & 21.30 & 0.527 & 0.430 & 0.054 & 0.022 & 0.043 & 0.032 & 0.032 & $€ 1$ & French & University of Rennes 1 & 35,194 & .327 \\
\hline Germany & 130 & 32 & 26.52 & 0.515 & 0.115 & 0.400 & 0.108 & 0.115 & 0.008 & 0.023 & $€ 1$ & German & Technical University, Berlin & 39,414 & .270 \\
\hline Guatemala & 84 & 1 & 22.20 & 0.464 & 0.345 & 0.179 & 0.000 & 0.119 & 0.036 & 0.131 & 6 Quetzales & Spanish & Universidad Francisco Marroquín & 4,961 & .559 \\
\hline India & 89 & 0 & 21.01 & 0.303 & 0.697 & 0.000 & 0.022 & 0.112 & 0.090 & 0.034 & 22 Rupees & English & University of Kolkata & 3,650 & .368 \\
\hline Japan & 84 & 0 & 21.74 & 0.512 & 0.095 & 0.417 & 0.107 & 0.107 & 0.000 & 0.048 & 120 Yen & Japanese & Hiroshima Shudo University & 34,278 & .376 \\
\hline Kyrgyzstan & 97 & 2 & 20.02 & 0.485 & 0.639 & 0.000 & 0.000 & 0.072 & 0.000 & 0.289 & $25 \mathrm{KGS}$ & Russian & University of Bishkek & 2,424 & .362 \\
\hline Malaysia & 64 & 0 & 20.09 & 0.578 & 0.578 & 0.188 & 0.062 & 0.000 & 0.016 & 0.047 & 2 Ringgit & English & University of Nottingham Malaysia & 15,589 & .462 \\
\hline Nicaragua & 120 & 1 & 20.94 & 0.550 & 0.917 & 0.025 & 0.000 & 0.000 & 0.000 & 0.000 & 10 Córdobas & Spanish & Universidad National Autonoma & 2,940 & .405 \\
\hline Nigeria & 202 & 2 & 22.65 & 0.495 & 0.406 & 0.000 & 0.005 & 0.054 & 0.312 & 0.119 & 110 Naira & English & University of Lagos & 2,532 & .437 \\
\hline Peru & 95 & 1 & 23.66 & 0.463 & 0.579 & 0.368 & 0.000 & 0.011 & 0.000 & 0.042 & 2 N. Soles & Spanish & Instituto del Peru & 10,318 & .460 \\
\hline Poland & 89 & 1 & 24.00 & 0.517 & 0.427 & 0.079 & 0.067 & 0.169 & 0.000 & 0.124 & 2.4 Zloty & Polish & University of Warsaw & 21,281 & .341 \\
\hline Russia & 70 & 8 & 20.56 & 0.500 & 0.729 & 0.129 & 0.000 & 0.086 & 0.000 & 0.014 & 22 Rubles & Russian & Higher School of Economics & 21,358 & .420 \\
\hline Saudi Arabia & 65 & 12 & 21.74 & 1.000 & 0.585 & 0.308 & 0.000 & 0.000 & 0.000 & 0.000 & 4 Riyal & English & King Fahd University & 24,434 & .570 \\
\hline South Africa & 71 & 18 & 22.44 & 0.606 & 0.451 & 0.254 & 0.056 & 0.056 & 0.014 & 0.042 & 8 Rand & English & University of Cape Town & 11,035 & .650 \\
\hline Spain & 80 & 3 & 20.94 & 0.513 & 0.450 & 0.037 & 0.000 & 0.100 & 0.037 & 0.225 & $€ 1$ & Spanish & Universidad Pompeu Fabra & 32,701 & .320 \\
\hline Thailand & 79 & 0 & 20.59 & 0.354 & 0.329 & 0.101 & 0.139 & 0.000 & 0.013 & 0.215 & 20 Baht & Thai & University of Khon Kaen & 8,703 & .536 \\
\hline Tunisia & 74 & 0 & 22.26 & 0.527 & 0.230 & 0.473 & 0.081 & 0.000 & 0.000 & 0.000 & 2 Dinar & French & Université Libre de Tunis & 9,415 & .400 \\
\hline UK & 80 & 0 & 20.77 & 0.450 & 0.700 & 0.000 & 0.025 & 0.013 & 0.025 & 0.075 & 1 Pound & English & King's College London & 36,511 & .350 \\
\hline USA & 97 & 22 & 21.32 & 0.495 & 0.144 & 0.206 & 0.113 & 0.041 & 0.031 & 0.186 & $\$ 1$ & English & University of Michigan Ann Arbor & 48,442 & .450 \\
\hline Vietnam & 87 & 0 & 20.20 & 0.575 & 0.667 & 0.057 & 0.034 & 0.000 & 0.011 & 0.023 & 8000 Dong & Vietnamese & Ho-Chi-Minh-City University & 3,435 & .357 \\
\hline Total & 2939 & 139 & 21.83 & 0.530 & 0.402 & 0.189 & 0.069 & 0.056 & 0.040 & 0.089 & & & & & \\
\hline
\end{tabular}

Sub.s stands for number of subjects, For.s for number of foreigners; econ etc. indicate study majors; PPP/€indicates exchange rates in purchasing power parity used for conversion Gini coefficients are taken from the World Bank where available, else from the CIA World Factbook; 2011 or closest available

GDP refers to 2011 values in PPP, current US Dollars; source: World Bank 


\section{References}

Abdellaoui, Mohammed, Aurélien Baillon, Lætitia Placido, and Peter P. Wakker (2011) 'The Rich Domain of Uncertainty: Source Functions and Their Experimental Implementation.' American Economic Review 101, 695-723

Ahn, David, Syngjoo Choi, Douglas Gale, and Shachar Kariv (2014) 'Estimating ambiguity aversion in a portfolio choice experiment.' Quantitative Economics 5(2), 195-223

Alary, David, Christian Gollier, and Nicolas Treich (2013) 'The Effect of Ambiguity Aversion on Insurance and Self-protection.' The Economic Journal 123(573), 11881202

Allen, Mary J, and Wendy M Yen (2001) Introduction to measurement theory (Waveland Press)

Ashraf, Quamrul, and Oded Galor (2013) "The "Out of Africa" Hypothesis, Human Genetic Diversity, and Comparative Economic Development.' The American Economic Review 103(1), 1-46

Baillon, Aurélien, and Han Bleichrodt (2015) 'Testing Ambiguity Models through the Measurement of Probabilities for Gains and Losses.' American Economic Journal: Microeconomics $7(2), 77-100$

Baillon, Aurélien, Han Bleichrodt, Umut Keskin, Olivier l'Haridon, and Chen Li (2016a) 'Learning under Ambiguity: An Experiment Using Initial Public Offerings on a Stock Market.' Management Science, forthcoming

Baillon, Aurélien, Zhenxing Huang, Asli Selim, and Peter P. Wakker (2016b) 'Measuring ambiguity attitudes for all (natural) events.' Working Paper

Baltussen, Guido, Martijn J. van den Assem, and Dennie van Dolder (2016) 'Risky choice in the limelight.' Review of Economics and Statistics 98(2), 318-332 
Becker, Anke, Thomas Dohmen, Benjamin Enke, and Armin Falk (2015) 'The Ancient Origins of the Cross-Country Heterogeneity in Risk Preferences.' Working Paper

Berger, Loïc, Han Bleichrodt, and Louis Eeckhoudt (2013) 'Treatment decisions under ambiguity.' Journal of Health Economics 32(3), 559-569

Binmore, Ken, Lisa Stewart, and Alex Voorhoeve (2012) 'How much ambiguity aversion?' Journal of Risk and Uncertainty 45(3), 215-238

Borghans, Lex, James J. Heckman, Bart H. H. Golsteyn, and Huub Meijers (2009) 'Gender Differences in Risk Aversion and Ambiguity Aversion.' Journal of the European Economic Association 7(2-3), 649-658

Bouchouicha, Ranoua, and Ferdinand M. Vieider (2017) 'Growth, entrepreneurship, and risk tolerance: A risk-income paradox.' University of Reading Working Paper

Bouchouicha, Ranoua, Peter Martinsson, Haileselassie Medhin, and Ferdinand Vieider (2016) 'Stake effects on ambiguity attitudes for gains and losses.' Theory 83 Decision, forthcoming

Brislin, Richard W. (1970) 'Back-translation for Cross-Cultural Research.' Journal of Cross-Cultural Psychology 1(3), 185-216

Bryan, Gharad (2010) 'Ambiguity and Insurance.' Working Paper

Charness, Gary, Edi Karni, and Dan Levin (2013) 'Ambiguity attitudes and social interactions: An experimental investigation.' Journal of Risk and Uncertainty 46(1), 1-25

Chow, Clare Chua, and Rakesh K. Sarin (2001) 'Comparative Ignorance and the Ellsberg Paradox.' Journal of Risk and Uncertainty 22, 129-139

Chow, Clare Chua, and Rakesh K Sarin (2002) 'Known, unknown, and unknowable uncertainties.' Theory and Decision pp. 127-138

Cohen, Michele, Jean-Yves Jaffray, and Tanios Said (1987) 'Experimental Comparison of 
Individual Behavior under Risk and Uncertainty for Gains and for Losses.' Organizational Behavior and Human Decision Processes 39, 1-22

Dimmock, Stephen G., Roy Kouwenberg, and Peter P. Wakker (2015a) 'Ambiguity Attitudes in a Large Representative Sample.' Management Science 62(5), 1363-1380

Dimmock, Stephen G, Roy Kouwenberg, Olivia S Mitchell, and Kim Peijnenburg (2015b) 'Estimating ambiguity preferences and perceptions in multiple prior models: Evidence from the field.' Journal of risk and uncertainty 51(3), 219-244

Easly, David, and Maureen O'Hara (2009) 'Ambiguity and Nonparticipation: The Role of Regulation.' Review of Financial Studies 22(5), 1817-1843

Ellsberg, Daniel (1961) 'Risk, Ambiguity and the Savage Axioms.' Quarterly Journal of Economics 75(4), 643-669

Etchart-Vincent, Nathalie, and Olivier L'Haridon (2011) 'Monetary Incentives in the Loss Domain and Behavior toward Risk: An Experimental Comparison of Three Reward Schemes Inclusing Real Losses.' Journal of Risk and Uncertainty 42, 61-83

Falk, Armin, Anke Becker, Thomas Dohmen, Benjamin Enke, David Huffman, and Uwe Sunde (2015) 'The nature and predictive power of preferences: Global evidence.' Working paper

Fox, Craig R., and Amos Tversky (1995) 'Ambiguity Aversion and Comparative Ignorance.' Quarterly Journal of Economics 110(3), 585-603

Friedl, Andreas, Katharina Lima de Miranda, and Ulrich Schmidt (2014) 'Insurance demand and social comparison: An experimental analysis.' Journal of Risk and Uncertainty 48(2), 97-109

Frisch, Deborah, and Jonathan Baron (1988) 'Ambiguity and rationality.' Journal of Behavioral Decision Making 1(3), 149-157 
Giné, Xavier, Robert Townsend, and James Vickery (2008) 'Patterns of Rainfall Insurance Participation in Rural India.' World Bank Economic Review 22, 539-566

Hofstede, Geert H. (1980) Culture's consequences : international differences in workrelated values (Thousand Oaks, CA: Sage Publications)

Huang, Rocco (2007) 'Distance and Trade: Disentangling unfamiliarity effects and transport cost effects.' European Economic Review 51(1), 161-181

Kunreuther, Howard, Jacqueline Meszaros, Robin M. Hogarth, and Mark Spranca (1995) 'Ambiguity and underwriter decision processes.' Journal of Economic Behavior \&f Organization 26(3), 337-352

La Porta, Rafael, Florencio Lopez-De-Silanes, Andrei Shleifer, and Robert W. Vishny (1997) 'Legal Determinants of External Finance.' The Journal of Finance 52(3), 11311150

L'Haridon, Olivier, and Ferdinand M. Vieider (2016) 'All over the map: Heterogeneity of risk preferences across individuals, contexts, and countries.' EM-DP2016-04, University of Reading

Mukerji, Sujoy (1998) 'Ambiguity Aversion and Incompleteness of Contractual Form.' The American Economic Review 88(5), 1207-1231

Muthukrishnan, A. V., Luc Wathieu, and Jing Alison Xu (2009) 'Ambiguity Aversion and the Preference for Established Brands.' Management Science 55(12), 1933-1941

Oechssler, Jörg, and Alex Roomets (2015) 'A test of mechanical ambiguity.' Journal of Economic Behavior \& Organization 119, 153-162

Powell, Melanie, and David Ansic (1997) 'Gender differences in risk behaviour in financial decision-making: An experimental analysis.' Journal of Economic Psychology $18(6), 605-628$ 
Rieger, Marc Oliver, Mei Wang, and Thorsten Hens (2014) 'Risk Preferences Around the World.' Management Science 61(3), 637 - 648

Snijders, Tom A. B., and Roel J. Bosker (2012) Multilevel Analysis: An Introduction to Basic and Advanced Multilevel Modeling, 2nd ed. (London: Sage PUblications)

Spolaore, Enrico, and Romain Wacziarg (2009) 'The Diffusion of Development.' The Quarterly Journal of Economics 124(2), 469-529

Stahl, Dale O. (2014) 'Heterogeneity of Ambiguity Preferences.' Review of Economics and Statistics 96(4), 609-617

Sutter, Matthias, Martin G Kocher, Daniela Glätzle-Rützler, and Stefan T Trautmann (2013) 'Impatience and Uncertainty: Experimental Decisions Predict Adolescents' Field Behavior.' American Economic Review 103(1), 510-531

Train, Kenneth (2009) Discrete choice methods with simulation (Cambridge; New York: Cambridge University Press)

Trautmann, Stefan T., and Gijs van de Kuilen (2015) 'Ambiguity Attitudes.' In 'The Wiley Blackwell Handbook of Judgment and Decision Making' (Wiley Blackwell)

Trautmann, Stefan T., Ferdinand M. Vieider, and Peter P. Wakker (2011) 'Preference Reversals for Ambiguity Aversion.' Management Science 57(5), 1320-1333

Tversky, Amos, and Craig R. Fox (1995) 'Weighing Risk and Uncertainty.' Psychological Review 102(2), 269-283

Vieider, Ferdinand M. (2012) 'Moderate stake variations for risk and uncertainty, gains and losses: methodological implications for comparative studies.' Economics Letters $117,718-721$

Vieider, Ferdinand M., Abebe Beyene, Randall A. Bluffstone, Sahan Dissanayake, Zenebe Gebreegziabher, Peter Martinsson, and Alemu Mekonnen (2016) 'Measuring risk pref- 
erences in rural Ethiopia.' Economic Development and Cultural Change, forthcoming Vieider, Ferdinand M., Mathieu Lefebvre, Ranoua Bouchouicha, Thorsten Chmura, Rustamdjan Hakimov, Michal Krawczyk, and Peter Martinsson (2015a) 'Common components of risk and uncertainty attitudes across contexts and domains: Evidence from 30 countries.' Journal of the European Economic Association 13(3), 421-452

Vieider, Ferdinand M., Thorsten Chmura, Tylor Fisher, Takao Kusakawa, Peter Martinsson, Frauke Mattison Thompson, and Adewara Sunday (2015b) 'Within- versus Between-Country Differences in Risk Attitudes: Implications for Cultural Comparisons.' Theory and Decision 78(2), 209-218

von Gaudecker, Hans-Martin, Arthur van Soest, and Erik Wengström (2011) 'Heterogeneity in Risky Choice Behaviour in a Broad Population.' American Economic Review 101(2), 664-694 


\section{APPENDIX: FOR ONLINE PUBLICATION ONLY}

\section{Consistency checks and attenuation anaylsis}

\section{Consistency checks}

In the main text, we only used stimuli with zero lower outcomes in order to keep our analysis simple. We can, however, now use the four additional choice list pairs providing non-zero lower outcomes to test for consistency of responses. In particular, the choice list pairs with probabilities $1 / 8$ and $7 / 8$ were repeated with a lower outcome consisting of the PPP-equivalent of $€ 5$ instead of 0 . Notice how this mimics the repetition by Dimmock et al. (2015b) of some choices with a probability of the known urn of plus or minus $10 \%$.

Indeed, taking the 0 lower outcome away and replacing it with $€ 5$ reduces the ambiguity of a choice, since the complementary probability is now assigned to a positive outcome (and vice versa for losses). This in turn means that ambiguity aversion predicts that ambiguity premia for the prospects with non-zero lower outcomes $(i / 8: x ; 5)$ with $i=1,7$ ought not to be larger than those for the matched list pairs with zero lower outcomes (in absolute value) $(i / 8: x ; 0)$. Similarly, ambiguity seeking predicts that ambiguity premia for the prospects with non-zero lower outcomes ought not to be lower than those for the matched list pairs with zero lower outcomes. For losses, both predictions have opposite signs.

Table 2 shows the number of choices incompatible with ambiguity aversion and ambiguity seeking for each of the four possible comparisons between prospects. Table 2 also shows the percentage of choices incompatible with either ambiguity aversion or ambiguity seeking in the four additional choice lists. Our empirical data indicate moderate propor- 
tions of violations, around 24 to $28 \%$. Notice how the figures are similar to the violation rates reported by Dimmock et al. (2015b), who reported that $42 \%$ of subjects responded in an inconsistent manner (not counting indifferences). This provides evidence that the levels of nosie in the two data sets are indeed quite similar.

\begin{tabular}{rrrrr}
\hline & Gains, $i=1$ & Gains, $i=7$ & Losses, $i=1$ & Losses, $i=7$ \\
\hline nbr. ambiguity aversion & 432 & 623 & 439 & 372 \\
nbr. ambiguity seeking & 235 & 161 & 166 & 336 \\
total percentage violations & 23.75 & 27.91 & 21.57 & 25.23 \\
\hline
\end{tabular}

Table 2: Consistency check: number and percentage of incompatible repeated choices

\section{Out of sample predictions}

We used the individual-level parameters generated from the multilevel regression model described by Eq. (6) to generate out-of-sample predictions for the prospects $(i / 8: x ; 5)$ with $i=1,7$. These predictions assume that utility is linear. With non-linear utilities, utility of outcome $y=5$ remains unkown and in-sample predictions of ambiguitiy premia on prospects $(i / 8: x ; 0), i=1,2,3,5,6,7$ cannot be directly used to generated out-ofsample predictions of ambiguity premia on $(i / 8: x ; 5), i=1,7$.

Table 3 shows the Spearman correlation coefficients for the comparisons between the elicited ambiguity premia and the predicted premia on prospects $(i / 8: x ; 5), i=1,7$ for gains and losses.

\begin{tabular}{rrrrr}
\hline & Gains, $i=1$ & Gains, $i=7$ & Losses, $i=1$ & Losses, $i=7$ \\
\hline correlation & 0.229 & 0.466 & 0.109 & 0.096 \\
p-value & $<0.001$ & $<0.001$ & $<0.001$ & $<0.001$ \\
$\mathrm{~N}$ & 2808 & 2810 & 2802 & 2803 \\
\hline
\end{tabular}

Table 3: Descriptive statistics out-of-sample predictions,

The low level of correlation between the measured ambiguity premia and the predicted ambiguity premia found in out-of-sample predictions is confirmed by the Spearman cor- 
relations between the measurements on prospects $(i / 8: x ; 0)$ and $(i / 8: x ; 5), i=1,7$. Table 4 shows these correlations for ambiguity premia. For the sake of comparison Table 4 also shows the correlations for the certainty equivalents under risk and under uncertainty. Table 4 shows that correlations between measurements on prospects $(i / 8: x ; 0)$ and $(i / 8: x ; 5), i=1,7$ were not only low in absolute terms, but also much lower for ambiguity premia than for certainty equivalents unde risk and uncertainty.

\begin{tabular}{rrrrr}
\hline & Gains, $i=1$ & Gains, $i=7$ & Losses, $i=1$ & Losses, $i=7$ \\
\hline ambiguity premia & 0.239 & 0.535 & 0.398 & 0.350 \\
certainty equivalents, risk & 0.439 & 0.694 & 0.592 & 0.660 \\
certainty equivalents, uncertainty & 0.441 & 0.686 & 0.633 & 0.720 \\
\hline
\end{tabular}

Table 4: correlations between measurements on prospects $(i / 8: x ; 0)$ and $(i / 8: x ; 5), i=1,7$.

\section{Relations of dominance between prospects}

In this section we provide evidence on the violations of first-order stochastic dominance between prospects. Two type of relations of dominance can be investigated with our data. First, we can compare the certainty equivalents for prospects $(i / 8: x ; 0)$ and $(j / 8: x ; 0)$, where $i$ and $j$ denote the number of balls associate with the highest outcome in absolute value. For gain prospects, the relation of dominance implies:

$$
i>j \Leftrightarrow c e_{i+}^{r} \geq c e_{j+}^{r} \text { and } c e_{i+}^{u} \geq c e_{j+}^{u}
$$

and similarly, for losses:

$$
i<j \Leftrightarrow c e_{i-}^{r} \geq c e_{j-}^{r} \text { and } c e_{i-}^{u} \geq c e_{j-}^{u}
$$

Second, we can compare the certainty equivalents for prospects $(i / 8: x ; 0)$ and $(i / 8$ : 
$x ; 5)$, with $i=1,7$. For gains, the relation of dominance implies that the certainty equivalent for $(i / 8: x ; 5)$ is larger or equal the certainty equivalent for $(i / 8: x ; 0)$. For losses, the relation of dominance implies the opposite.

Relations of dominance between prospects $(i / 8: x ; 0)$ and $(j / 8: x ; 0)$

Our data contains 6 rank-ordered prospects in terms of likelihoods $i / 8(i=1,2,3,5,6,7)$. This implies 15 possible comparisons in terms of first order stochatic dominance. For each subject and for each of these possible violations violations, we evaluated the violations of first-order stochastic dominance for gains and losses, under risk and uncertainty.

Table 5 shows the average percentages of violations of first-order stochastic dominance for gains and losses under risk. Numbers below the diagonal correspond to the percentage of violations in the gain domain. Numbers above the diagonal correspond to the percentage of violations in the loss domain.

\begin{tabular}{rrrrrrr}
\hline & $j=1$ & $j=2$ & $j=3$ & $j=5$ & $j=6$ & $j=7$ \\
\hline$i=1$ & & 14.25 & 11.65 & 8.35 & 7.29 & 6.20 \\
$i=2$ & 20.65 & & 13.19 & 7.87 & 6.54 & 6.17 \\
$i=3$ & 16.37 & 13.85 & & 8.45 & 6.64 & 6.61 \\
$i=5$ & 7.66 & 6.77 & 7.25 & & 11.55 & 8.14 \\
$i=6$ & 6.60 & 5.89 & 6.60 & 11.50 & & 10.18 \\
$i=7$ & 6.06 & 5.85 & 5.96 & 7.42 & 9.19 & \\
\hline
\end{tabular}

Table 5: Average percentage violations of First-Order Stochastic Dominance under risk

Table 6 shows the average percentages of violations of first-order stochastic dominance for gains and losses under uncertainty. Numbers below the diagonal correspond to the percentage of violations in the gain domain. Numbers above the diagonal correspond to the percentage of violations in the loss domain.

Comparison of Tables 5 and 6 shows that percentage of violations were comparable across sources of uncertainty and signs (gains vs. losses). We ran a two-way repeated- 


\begin{tabular}{rrrrrrr}
\hline & $j=1$ & $j=2$ & $j=3$ & $j=5$ & $j=6$ & $j=7$ \\
\hline$i=1$ & & 18.20 & 13.90 & 9.03 & 7.67 & 6.24 \\
$i=2$ & 17.93 & & 15.20 & 8.22 & 7.60 & 5.73 \\
$i=3$ & 13.44 & 13.47 & & 8.93 & 7.43 & 6.24 \\
$i=5$ & 8.00 & 8.55 & 8.89 & & 12.44 & 8.63 \\
$i=6$ & 7.11 & 7.45 & 8.03 & 12.19 & & 10.84 \\
$i=7$ & 5.89 & 6.02 & 6.47 & 9.64 & 11.20 & \\
\hline
\end{tabular}

Table 6: Average percentage violations of First-Order Stochastic Dominance under uncertainty

measure ANOVA, with sign (gains vs. losses) as the first factor and source of uncertainty as the second factor, on the percentage of first-order stochastic dominance violations. The value of the intercept is $8.9 \%$ (p-value: 0 ). We found no evidence for a sign effect (coefficient on gain dummy: 0.003, p-value: 0.392). We found a significant source effect, but with a rather small coefficient for the uncertainty dummy (coefficient equal to 0.009, p-value: 0.002). Therefore, uncertainty raised modestly the percentage of first-order stochastic dominance violations by $0.9 \%$. We found no interaction between source and sign (p-value: 0.283$)$.

Last, we show evidence for violations of first-order stochastic dominance at the individual level. Figure 5 shows the four possible comparisons at the subject level.

Relations of dominance between prospects $(i / 8: x ; 0)$ and $(i / 8: x ; 5)$

Our data contains 8 pairs of rank-ordered prospects in terms of outcomes: two in the gain domain with $i=1,7$ under risk and under uncertainty, two in the loss domain under risk and under uncertainty. Table 7 shows the average percentages of violations of first-order stochastic dominance for gains and losses under risk. Numbers below the diagonal correspond to the percentage of violations in the gain domain. Numbers above the diagonal correspond to the percentage of violations in the loss domain.

Table 8 shows the average percentages of violations of first-order stochastic domi- 

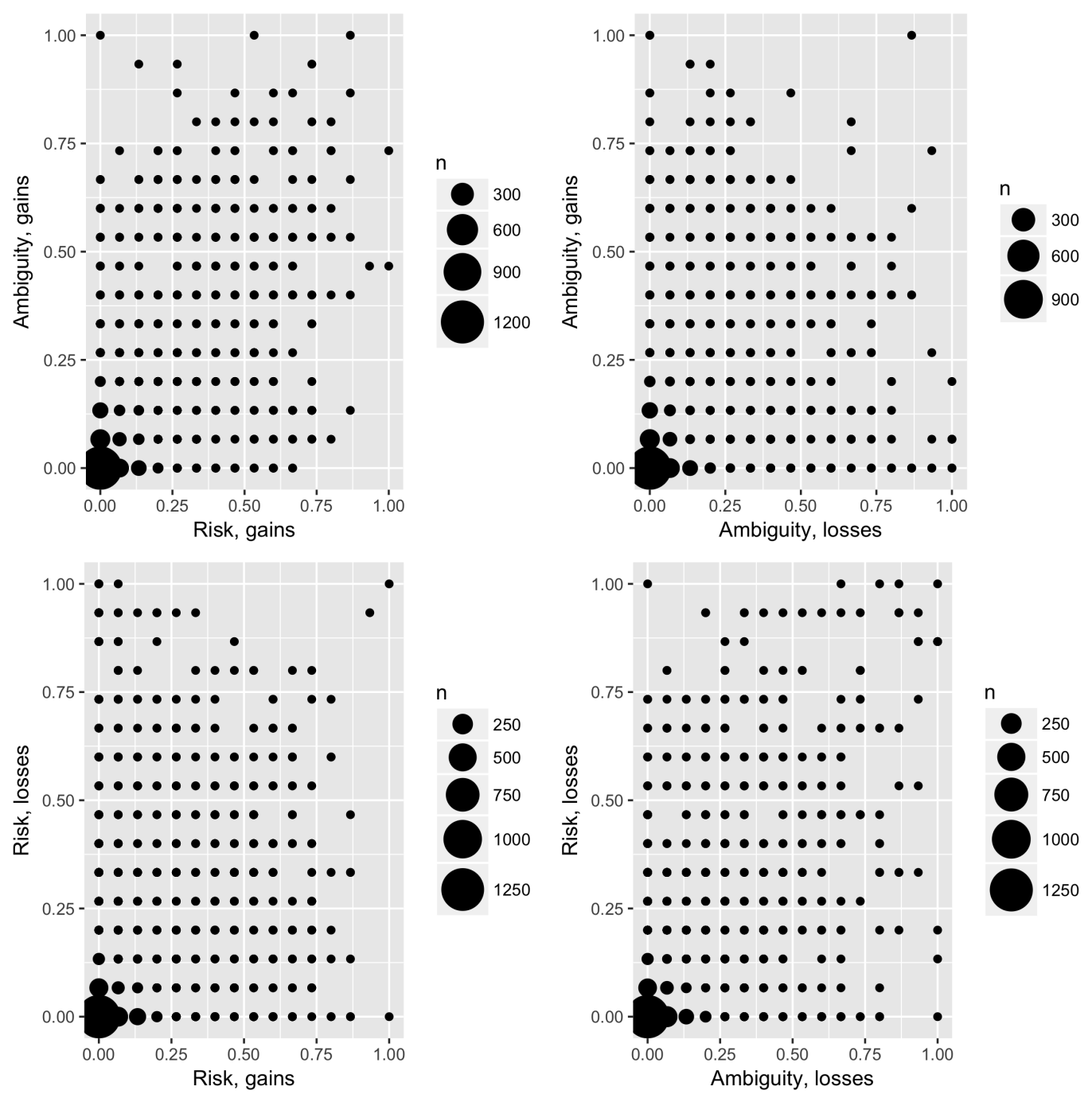

Figure 5: Individual violations of first-order stochastic dominance on prospects $(i / 8: x ; 0)$ and $(j / 8$ : $x ; 0), i=1,2,3,5,6,7$

nance for gains and losses under risk. Numbers below the diagonal correspond to the percentage of violations in the gain domain. Numbers above the diagonal correspond to the percentage of violations in the loss domain.

Comparison of Tables 7 and 8 shows that percentage of violations were comparable across sources of uncertainty and signs (gains vs. losses). We ran a two-way repeatedmeasure ANOVA, with sign (gains vs. losses) as the first factor and source of uncertainty as the second factor, on the percentage of dominance relations. The value of the intercept is $19.9 \%$ (p-value: 0 ). We found evidence for a sign effect (coefficient on gain dummy:0.064, p-value: <0.001). We also found a significant source effect, with smaller coefficient 


\begin{tabular}{rrrrr}
\hline & $y=0, i=1$ & $y=5, i=1$ & $y=0, i=7$ & $y=5, i=7$ \\
\hline$y=0, i=1$ & & & \\
$y=5, i=1$ & & & \\
$y=0, i=7$ & 8.97 & & & \\
$y=5, i=7$ & & 17.93 & \\
$y$
\end{tabular}

Table 7: Average percentage violations of First-Order Stochastic Dominance under risk, assuming linear utility

\begin{tabular}{lrrrr}
\hline & $y=0, i=1$ & $y=5, i=1$ & $y=0, i=2$ & $y=5, i=2$ \\
\hline$y=0, i=1$ & & & \\
$y=5, i=1$ & & & & 269 \\
$y=0, i=2$ & 6.37 & & \\
$y=5, i=2$ & & 12.03 & \\
\hline
\end{tabular}

Table 8: Average percentage violations of First-Order Stochastic Dominance under uncertainty, assuming linear utility

(coefficient for the uncertainty dummy equals to -0.024, p-value: -0.001). Therefore, both losses and risk raised the percentage of first-order stochastic dominance violations by $2.4 \%$. We also found interaction between source and sign to be significant (p-value: 0.025). Figure 6 shows the comparisons of violations of first-order stochastic dominance at the individual level. 


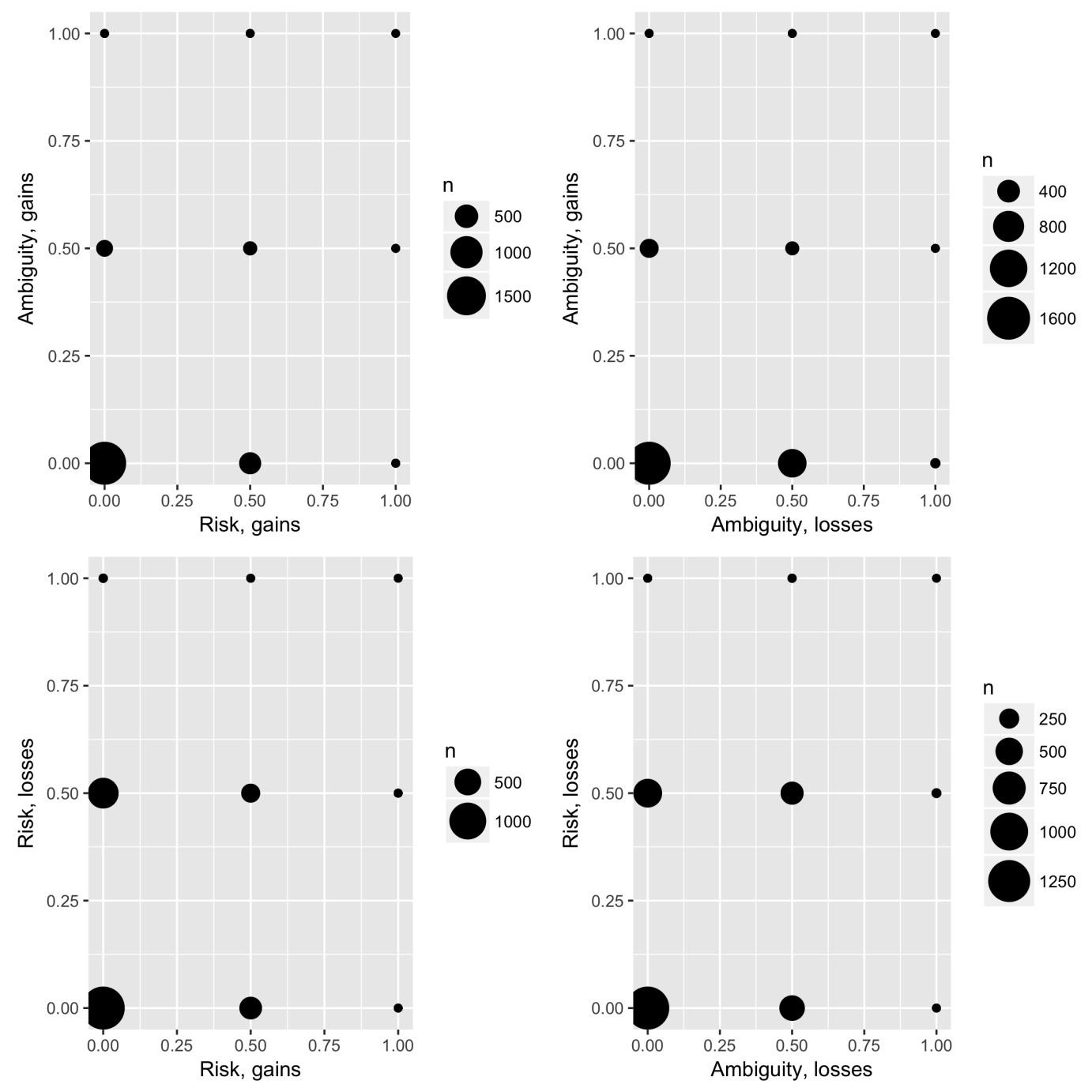

Figure 6: Individual violations of first-order stochastic dominance on prospects $(i / 8: x ; 0)$ and $(i / 8$ : $x ; 5), i=1,7$

\section{Distrust of the experimenter: Pilot results}

\section{Methods and setup}

We recruited 89 subjects at the Technical University Berlin, Germany, where also the main experiment was run. Of these, we randomly allocated 41 to a baseline which closely imitated the original experimental design. The remaining 48 were allocated to a treatment meant to test whether trust in the experimenter influenced the findings.

In general, we followed the procedures of the main experiment closely. The experiment was conducted using paper and pencil. Decision tasks with nonzero lower outcomes 
and probabilities different from 0.5 were dropped from the task, in order to make the experiment somewhat shorter; and subjects were not forbidden to switch to and fro between the prospect and the sure amount. This serves to make the data comparable with the evidence collected, while at the same time abandoning some or the more restrictive assumptions.

In the baseline experiment, fixed numbers were assigned to the balls in the uncertain urn, equivalent to those of the risky urn. The treatment consisted in giving subjects a choice what balls (numbers) to bet on. Instead of assigning fixed numbers to the winning and losing balls, subjects were told that they would have to choose the numbers on which they wanted to bet. Only blank balls were displayed in the decision problems, so that subjects could write their own numbers on the balls. This procedure thus emulates the common precaution in 50-50 Ellsberg problems whereby subjects are allowed to choose the colour they want to bet on. See also Abdellaoui et al. (2011) for an analogous implementation using eight coloured balls.

The null hypotheses is that it makes no difference whether subjects are allowed to choose the numbers to bet on or whether these numbers are pre-assigned, i.e. that mistrust of the experimenter plays no significant role for ambiguity attitudes. The alternative hypothesis is that we will find more ambiguity aversion when the numbers of the winning balls are preassigned. These hypotheses can be further refined according to the winning probabilities and the decision domains.

\section{Results}

Figure 7 shows the nonparametric ambiguity premia separately for each prospect pair.

Figure 7(a) shows the results for gains, juxtaposing the baseline and treatment conditions. 
It can easily be seen that no significant differences arise between the treatments. This result holds either with a parametric t-test, or with a nonparametric Mann-Whitney test. We observe a similar result for losses, shown in figure 7(b). The equality of ambiguity premia observed is indeed very clear for probabilities $p \geq 0.25$. While for the smallest probability it would appear that subjects are more ambiguity averse in the baseline treatment, this is not significant at conventional levels either using a t-test $(t(87)=1.60, p=0.112)$, or using a Mann-Whitney test $(z=1.65, p=0.099)$. We thus conclude that mistrust towards the experimenter does not play a major role for our results.

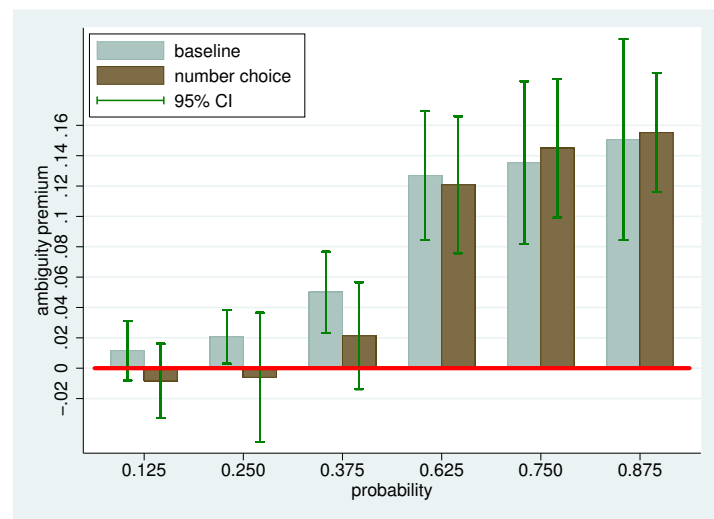

(a) gains

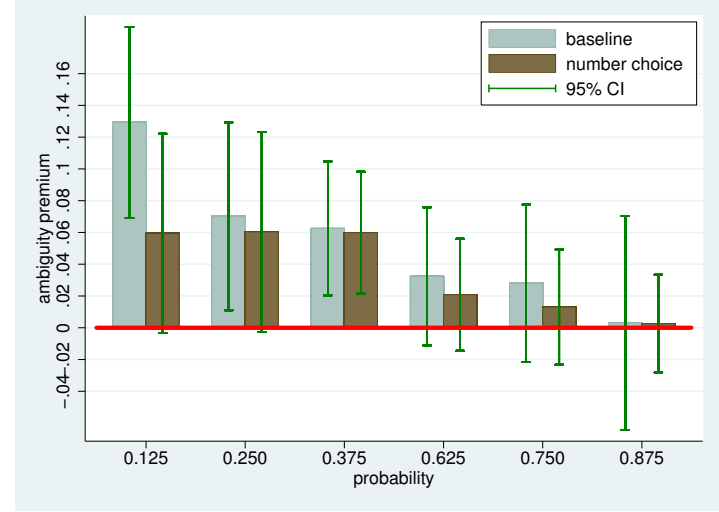

(b) losses

Figure 7: Differences by treatment 
Instructions 


\section{$\underline{\text { Instructions }}$}

Thank you for participating in this experiment in decision making! You will obtained 4 Euros for having come to the experiment - those 4 Euros are yours to keep independently of the outcomes in the experiment. In addition, you will be compensated with whatever you earn during the experiment according to the procedures described in the instructions.

The instructions will be read to you in a short while. You may consult these instructions at any time during the experiment. In case you should have any questions or doubts, please raise your hand and an experimenter will come and assist you in private.

Please consider each decision carefully. Take a careful look at outcomes and the probabilities associated to them before taking a decision. Remember that your final payoffs from this experiment will depend on the decisions you make (and of course, on chance).

Please remain seated when you are finished with the tasks. This experiment consists of two parts. Once everybody has finished the tasks in part I, new instructions will be read to you for part II. At the very end of the experiment, you will be asked to fill out a questionnaire. The answer to the questionnaire as well as all your answers to the tasks will be private, and cannot be traced back to you personally. Once you are done filling in the questionnaire, an experimenter will call you up. Your payoff will then be determined in private, you will be given the money you won, after which you can leave.

Do not talk during the experiment, or you will be immediately excluded from the experiment !

Good luck! 


\section{PART I}

\section{Choice tasks}

In the present experiment, you will be asked to choose repeatedly between a fixed amount of money and a lottery. The lottery will always give you a chance to win one of two amounts of money. Figure 1 shows a typical choice task. You are asked repeatedly to choose between playing the lottery and obtaining a sure amount of money. For each row, you are asked to indicate whether you would prefer to play the lottery or to obtain the sure amount of money by ticking the preferred option.

The urn indicated in the figure contains eight numbered balls. One ball will be extracted from the urn to determine your payoffs in case you should play the lottery. In the lottery displayed, if ball 1 , 2,3 , or 4 is extracted, you obtain $€ 10$; if ball $5,6,7,8$ is extracted, you obtain nothing. Please pay close attention to the amounts to be won as well as the number of balls associated with each outcome, since they change across decisions.

Fig. 1: Example of a typical decision task

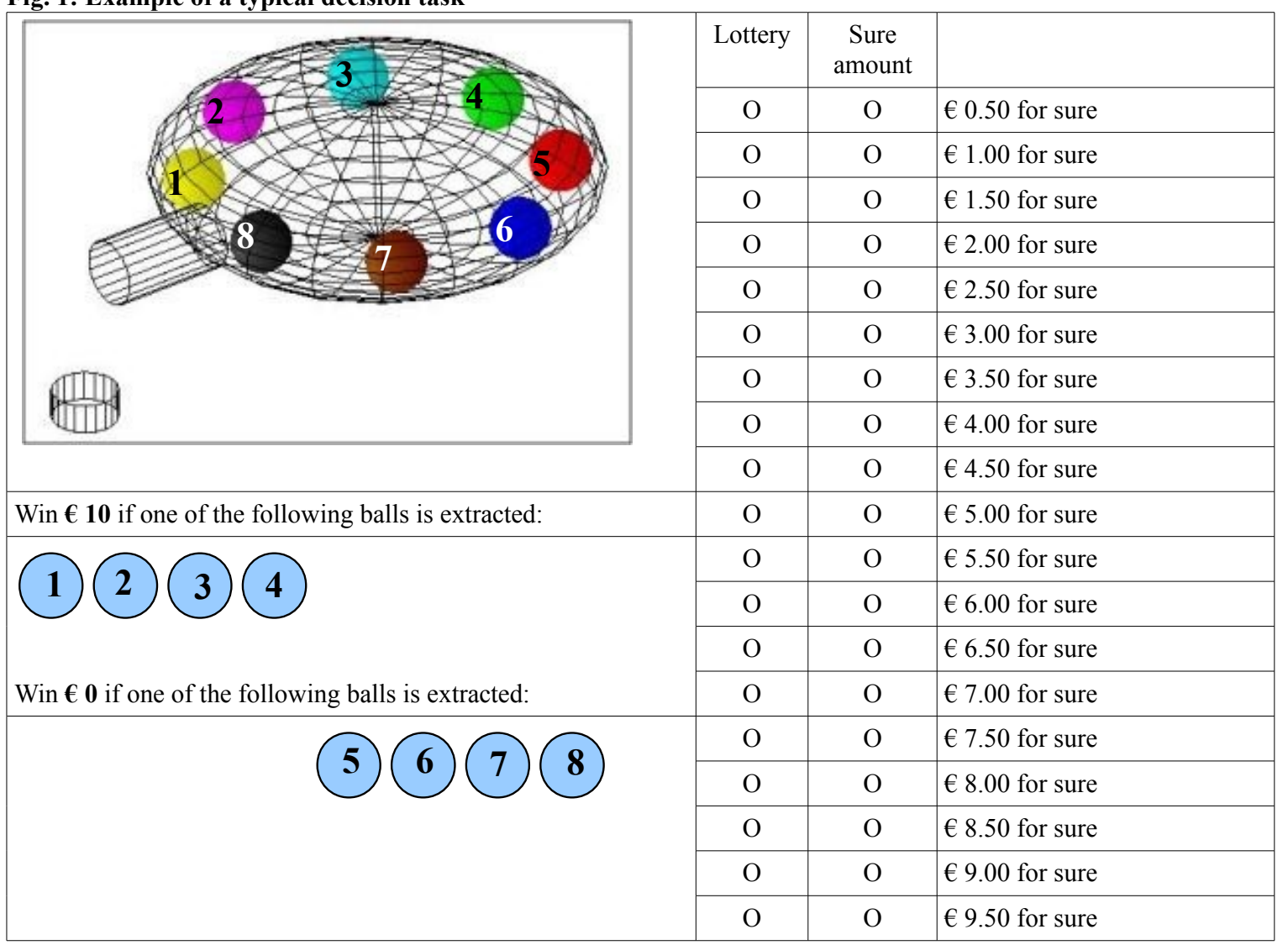

We are interested in the amount for which you will switch from preferring the lottery to preferring the sure amount. Most likely, you will begin by choosing the lottery for small sure amounts, and at a certain point switch to the sure amount as the latter increases. If you do not want the lottery at all, you can choose to get the sure amount in the first row and then continue with the sure amount for all choices (if you prefer $€ 0.50$ over the lottery you should also prefer $€ 1.00$ over the lottery, etc.).

Where you will switch from the lottery to the sure amount depends entirely on your preferencesthere are no right or wrong answers. However, you should NOT switch back and forth several times between lottery and sure amount! You will be excluded from the experiment if you do so or if it is not possible to clearly recognize your preference (for example, if you have not ticked any box for a given row or ticked both boxes for a given row). 


\section{Types of choices}

You will be asked to take 18 decisions, for each one of which you will need to decide between a lottery and a series of sure amounts as exemplified in figure 1 above. Please pay close attention to the amounts to be won as well as the number of balls associated with each outcome! Indeed, both the higher and lower amount, as well as the number of balls, change between decision problems. Since your final payoff depends on these decisions, it is crucial for you to pay close attention to these features.

There are two different types of lotteries involved. Figure 2 below shows the two different types of lotteries that you will encounter. Fig 2a shows the urn already familiar from figure 1 above. It contains exactly eight (8) balls, numbered from 1 to 8.

In Urn in Fig. $2 \mathrm{~b}$ also contains exactly eight (8) balls. However, you cannot see what numbers the balls contained in the urn have. This means that you do not know the exact numbers that are present in that urn. All balls bear a number between 1 and 8 inclusive (have either 1,2, 3, 4, 5, 6,7 , or 8 written on them), but it is possible that some numbers are absent from this urn while others occur repeatedly. Thus you do not know the exact composition of the urn.

Fig. 2a: transparent urn

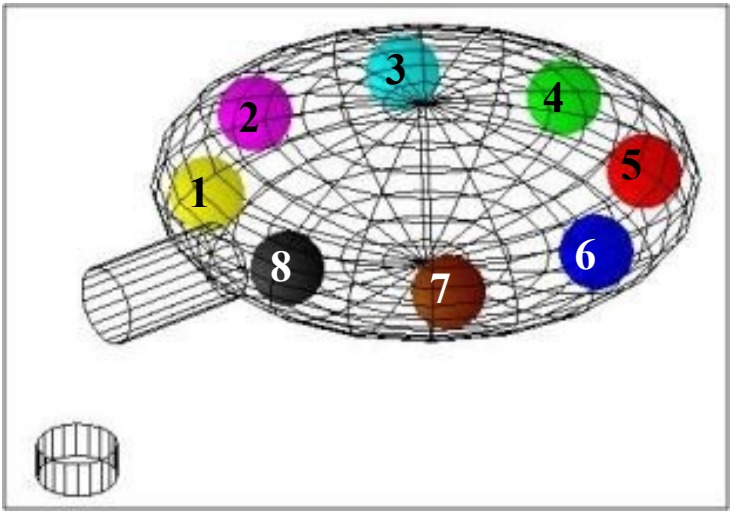

Fig. 2b: opaque urn

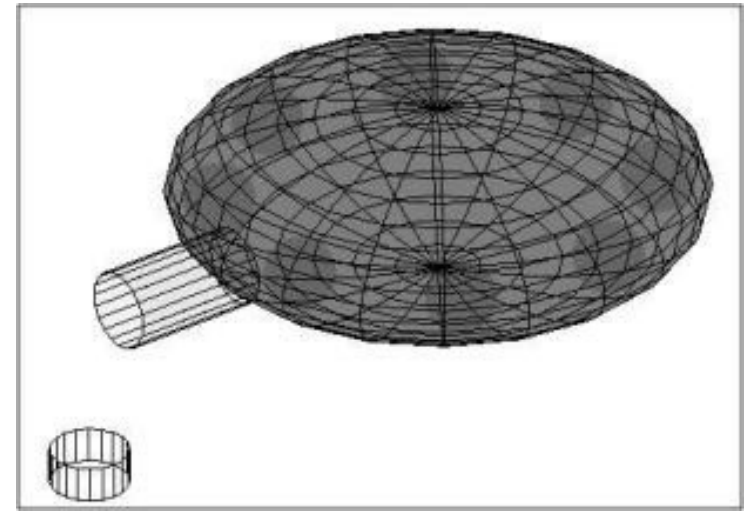

\section{Payoff determination}

After you have taken all the decisions, one of your decisions will be randomly drawn for real pay, i.e. the amounts indicated in the decision problem will be paid out for real. First, either part I or part II will be selected for real play by a coin flip. If part I is selected, then one of the 18 decision tasks is drawn at random, using a chance device with equal probability for each decision task to be extracted. For the extracted decision task, one of your decisions, corresponding to one row for which you had to indicate your preference between the sure amount and the lottery, will then be drawn at random with equal probability for each row. If for the row that is drawn you have indicated that you prefer the sure amount of money, you will simply be paid that amount.

In case you have chosen the lottery for the randomly determined row, then that lottery will be played according to the probabilities indicated. For the transparent urn, this will involve drawing a ball from an urn in which all numbers from 1 to 8 inclusive are present. If you should desire to do so, you can verify that there are indeed all balls from 1 to 8 in the urn. You will then be paid the outcome corresponding to the ball you drew.

For the opaque urn, the procedure is exactly analogous, except that you will now draw a ball from a pre-composed urn, the exact composition of which you do not know. You will also be paid the outcome corresponding to the ball you drew. If you should desire to do so, after the draw you can verify that there are indeed 8 balls with numbers between 1 and 8 inclusive in the urn. 


\section{Decision 1}

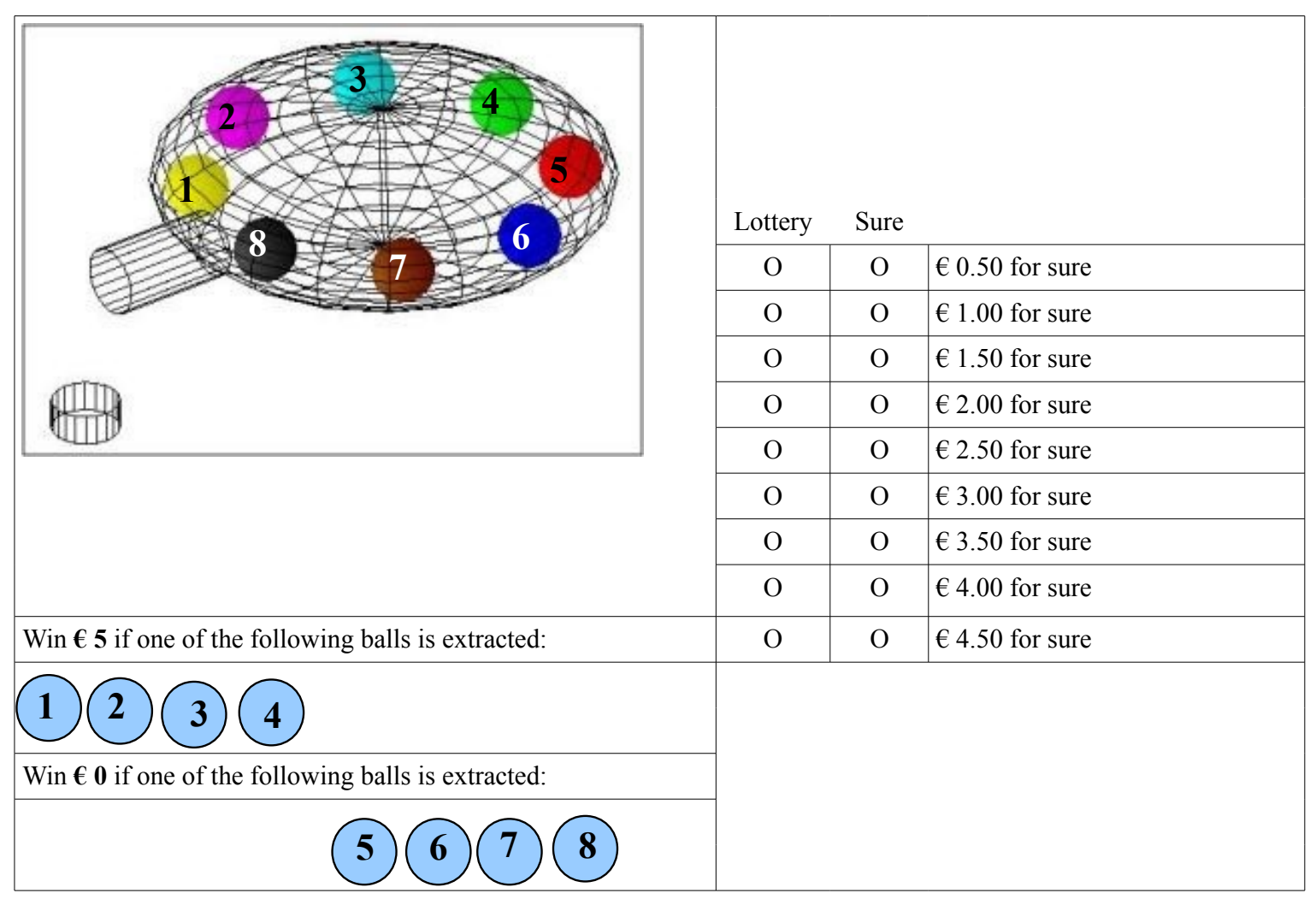




\section{Decision 2}

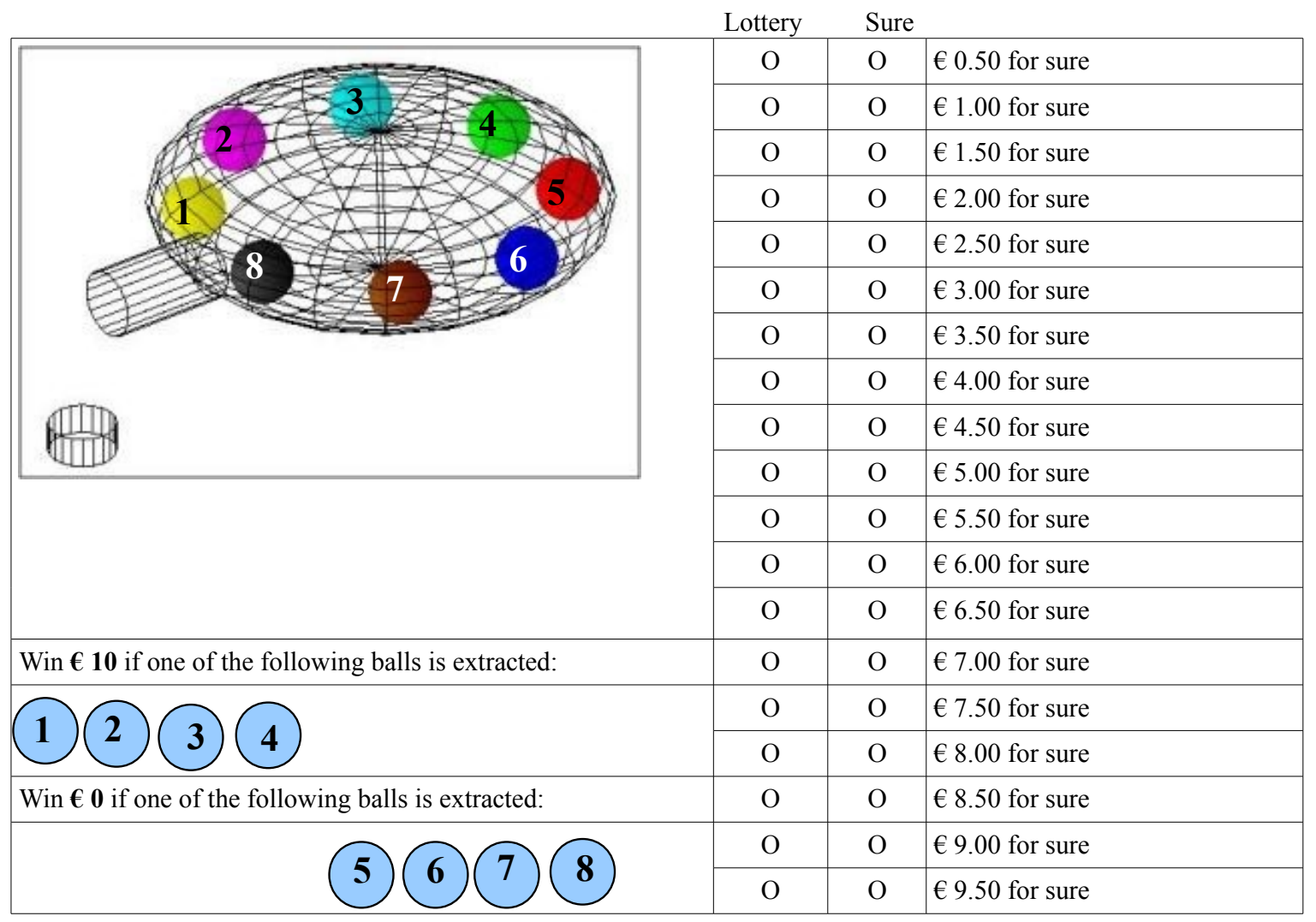




\section{Decision 3}

Lottery Sure

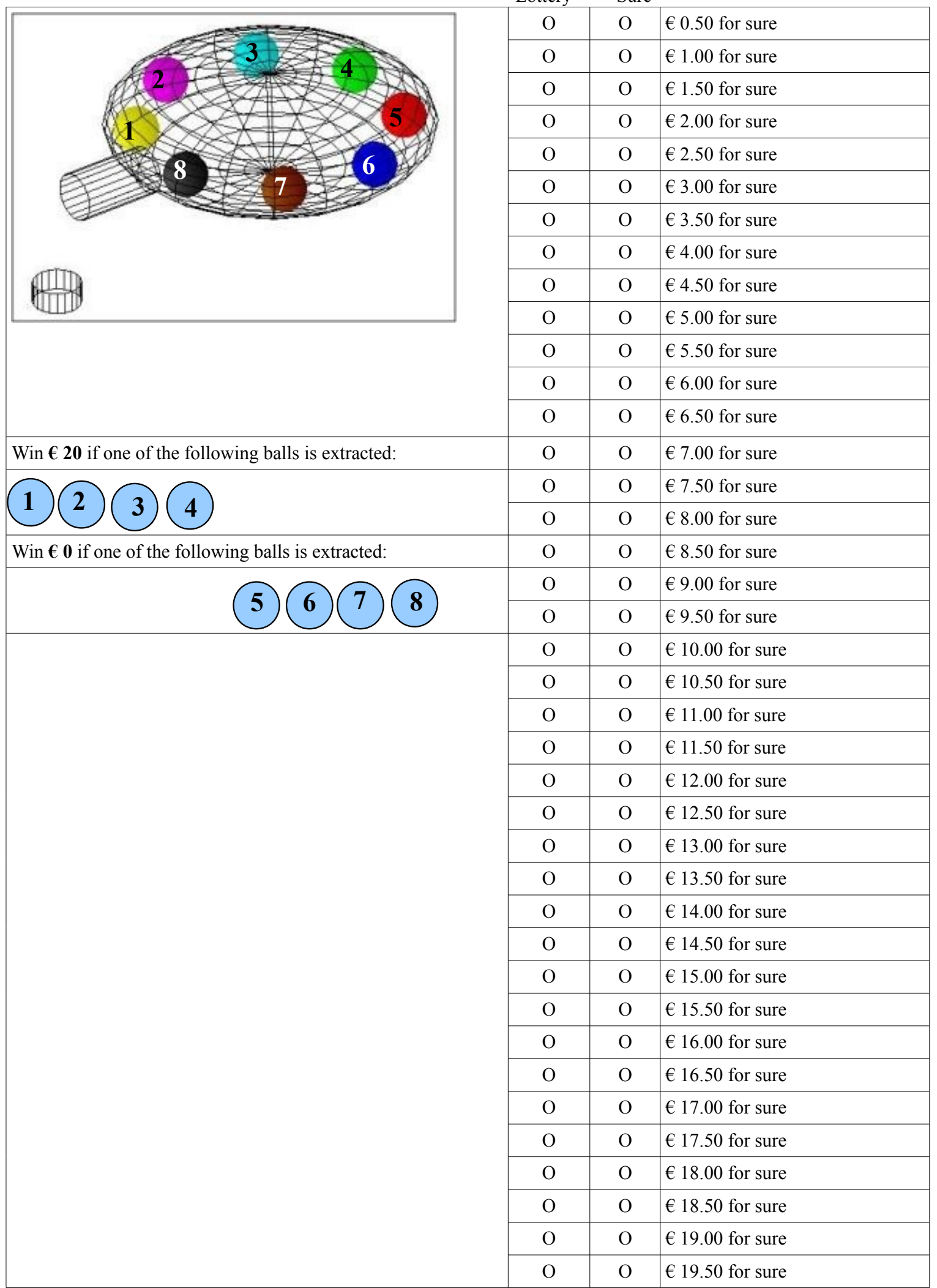




\section{Decision 4}

\begin{tabular}{|c|c|c|c|}
\hline & Lottery & Sul & \\
\hline & $\mathrm{O}$ & $\mathrm{O}$ & $€ 5.50$ for sure \\
\hline & $\mathrm{O}$ & $\mathrm{O}$ & $€ 6.00$ for sure \\
\hline & $\mathrm{O}$ & $\mathrm{O}$ & $€ 6.50$ for sure \\
\hline & $\mathrm{O}$ & $\mathrm{O}$ & $€ 7.00$ for sure \\
\hline & $\mathrm{O}$ & $\mathrm{O}$ & $€ 7.50$ for sure \\
\hline & $\mathrm{O}$ & $\mathrm{O}$ & $€ 8.00$ for sure \\
\hline & $\mathrm{O}$ & $\mathrm{O}$ & $€ 8.50$ for sure \\
\hline & $\mathrm{O}$ & $\mathrm{O}$ & $€ 9.00$ for sure \\
\hline & $\mathrm{O}$ & $\mathrm{O}$ & $€ 9.50$ for sure \\
\hline & $\mathrm{O}$ & $\mathrm{O}$ & $€ 10.00$ for sure \\
\hline & $\mathrm{O}$ & $\mathrm{O}$ & $€ 10.50$ for sure \\
\hline & $\mathrm{O}$ & $\mathrm{O}$ & $€ 11.00$ for sure \\
\hline & $\mathrm{O}$ & $\mathrm{O}$ & $€ 11.50$ for sure \\
\hline Win $€ \mathbf{3 0}$ if one of the following balls is extracted: & $\mathrm{O}$ & $\mathrm{O}$ & $€ 12.00$ for sure \\
\hline & $\mathrm{O}$ & $\mathrm{O}$ & $€ 12.50$ for sure \\
\hline & $\mathrm{O}$ & $\mathrm{O}$ & $€ 13.00$ for sure \\
\hline Win $€ \mathbf{0}$ if one of the following balls is extracted: & $\mathrm{O}$ & $\mathrm{O}$ & $€ 13.50$ for sure \\
\hline & $\mathrm{O}$ & $\mathrm{O}$ & $€ 14.00$ for sure \\
\hline & $\mathrm{O}$ & $\mathrm{O}$ & $€ 14.50$ for sure \\
\hline & $\mathrm{O}$ & $\mathrm{O}$ & $€ 15.00$ for sure \\
\hline & $\mathrm{O}$ & $\mathrm{O}$ & $€ 15.50$ for sure \\
\hline & $\mathrm{O}$ & $\mathrm{O}$ & $€ 16.00$ for sure \\
\hline & $\mathrm{O}$ & $\mathrm{O}$ & $€ 16.50$ for sure \\
\hline & $\mathrm{O}$ & $\mathrm{O}$ & $€ 17.00$ for sure \\
\hline & $\mathrm{O}$ & $\mathrm{O}$ & $€ 17.50$ for sure \\
\hline & $\mathrm{O}$ & $\mathrm{O}$ & $€ 18.00$ for sure \\
\hline & $\mathrm{O}$ & $\mathrm{O}$ & $€ 18.50$ for sure \\
\hline & $\mathrm{O}$ & $\mathrm{O}$ & $€ 19.00$ for sure \\
\hline & $\mathrm{O}$ & $\mathrm{O}$ & $€ 19.50$ for sure \\
\hline & $\mathrm{O}$ & $\mathrm{O}$ & $€ 20.00$ for sure \\
\hline & $\mathrm{O}$ & $\mathrm{O}$ & $€ 20.50$ for sure \\
\hline & $\mathrm{O}$ & $\mathrm{O}$ & $€ 21.00$ for sure \\
\hline & $\mathrm{O}$ & $\mathrm{O}$ & $€ 21.50$ for sure \\
\hline & $\mathrm{O}$ & $\mathrm{O}$ & $€ 22.00$ for sure \\
\hline & $\mathrm{O}$ & $\mathrm{O}$ & $€ 22.50$ for sure \\
\hline & $\mathrm{O}$ & $\mathrm{O}$ & $€ 23.00$ for sure \\
\hline & $\mathrm{O}$ & $\mathrm{O}$ & $€ 23.50$ for sure \\
\hline & $\mathrm{O}$ & $\mathrm{O}$ & $€ 24.00$ for sure \\
\hline & $\mathrm{O}$ & $\mathrm{O}$ & $€ 24.50$ for sure \\
\hline
\end{tabular}




\section{Decision 5}

\begin{tabular}{|c|c|c|c|}
\hline & Lottery & Sur & \\
\hline & $\mathrm{O}$ & $\mathrm{O}$ & $€ 10.50$ for sure \\
\hline & $\mathrm{O}$ & $\mathrm{O}$ & $€ 11.00$ for sure \\
\hline & $\mathrm{O}$ & $\mathrm{O}$ & $€ 11.50$ for sure \\
\hline & $\mathrm{O}$ & $\mathrm{O}$ & $€ 12.00$ for sure \\
\hline & $\mathrm{O}$ & $\mathrm{O}$ & $€ 12.50$ for sure \\
\hline & $\mathrm{O}$ & $\mathrm{O}$ & $€ 13.00$ for sure \\
\hline & $\mathrm{O}$ & $\mathrm{O}$ & $€ 13.50$ for sure \\
\hline & $\mathrm{O}$ & $\mathrm{O}$ & $€ 14.00$ for sure \\
\hline & $\mathrm{O}$ & $\mathrm{O}$ & $€ 14.50$ for sure \\
\hline & $\mathrm{O}$ & $\mathrm{O}$ & $€ 15.00$ for sure \\
\hline & $\mathrm{O}$ & $\mathrm{O}$ & $€ 15.50$ for sure \\
\hline & $\mathrm{O}$ & $\mathrm{O}$ & $€ 16.00$ for sure \\
\hline & $\mathrm{O}$ & $\mathrm{O}$ & $€ 16.50$ for sure \\
\hline Win $\boldsymbol{\epsilon} \mathbf{3 0}$ if one of the following balls is extracted: & $\mathrm{O}$ & $\mathrm{O}$ & $€ 17.00$ for sure \\
\hline & $\mathrm{O}$ & $\mathrm{O}$ & $€ 17.50$ for sure \\
\hline 1 & $\mathrm{O}$ & $\mathrm{O}$ & $€ 18.00$ for sure \\
\hline Win $€ \mathbf{1 0}$ if one of the following balls is extracted: & $\mathrm{O}$ & $\mathrm{O}$ & $€ 18.50$ for sure \\
\hline & $\mathrm{O}$ & $\mathrm{O}$ & $€ 19.00$ for sure \\
\hline & $\mathrm{O}$ & $\mathrm{O}$ & $€ 19.50$ for sure \\
\hline & $\mathrm{O}$ & $\mathrm{O}$ & $€ 20.00$ for sure \\
\hline & $\mathrm{O}$ & $\mathrm{O}$ & $€ 20.50$ for sure \\
\hline & $\mathrm{O}$ & $\mathrm{O}$ & $€ 21.00$ for sure \\
\hline & $\mathrm{O}$ & $\mathrm{O}$ & $€ 21.50$ for sure \\
\hline & $\mathrm{O}$ & $\mathrm{O}$ & $€ 22.00$ for sure \\
\hline & $\mathrm{O}$ & $\mathrm{O}$ & $€ 22.50$ for sure \\
\hline & $\mathrm{O}$ & $\mathrm{O}$ & $€ 23.00$ for sure \\
\hline & $\mathrm{O}$ & $\mathrm{O}$ & $€ 23.50$ for sure \\
\hline & $\mathrm{O}$ & $\mathrm{O}$ & $€ 24.00$ for sure \\
\hline & $\mathrm{O}$ & $\mathrm{O}$ & $€ 24.50$ for sure \\
\hline & $\mathrm{O}$ & $\mathrm{O}$ & $€ 25.00$ for sure \\
\hline & $\mathrm{O}$ & $\mathrm{O}$ & $€ 25.50$ for sure \\
\hline & $\mathrm{O}$ & $\mathrm{O}$ & $€ 26.00$ for sure \\
\hline & $\mathrm{O}$ & $\mathrm{O}$ & $€ 26.50$ for sure \\
\hline & $\mathrm{O}$ & $\mathrm{O}$ & $€ 27.00$ for sure \\
\hline & $\mathrm{O}$ & $\mathrm{O}$ & $€ 27.50$ for sure \\
\hline & $\mathrm{O}$ & $\mathrm{O}$ & $€ 28.00$ for sure \\
\hline & $\mathrm{O}$ & $\mathrm{O}$ & $€ 28.50$ for sure \\
\hline & $\mathrm{O}$ & $\mathrm{O}$ & $€ 29.00$ for sure \\
\hline & $\mathrm{O}$ & $\mathrm{O}$ & $€ 29.50$ for sure \\
\hline
\end{tabular}




\section{Decision 6}

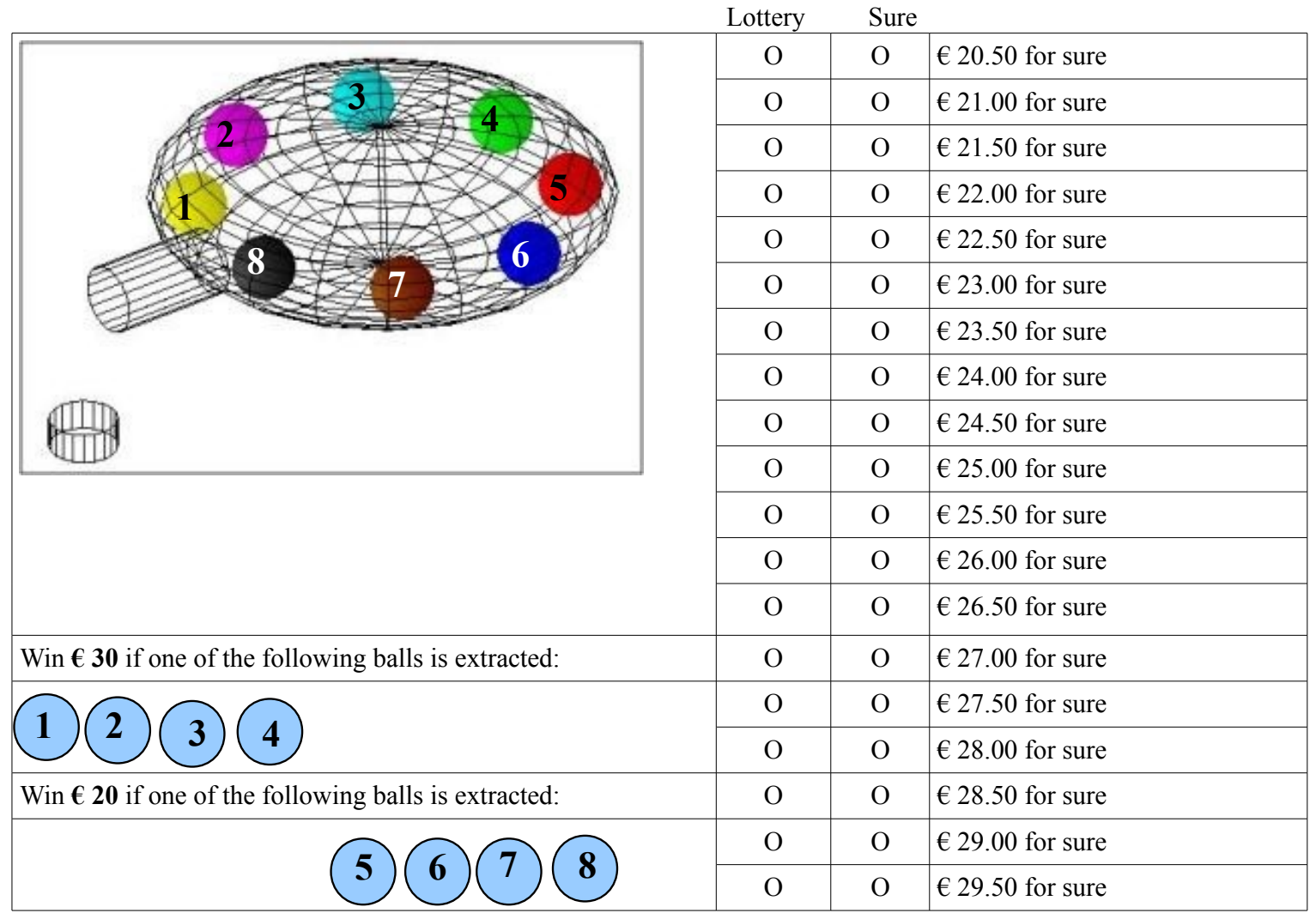




\section{Decision 7}

\begin{tabular}{|c|c|c|c|}
\hline & Lottery & Sur & \\
\hline & $\mathrm{O}$ & $\mathrm{O}$ & $€ 0.50$ for sure \\
\hline & $\mathrm{O}$ & $\mathrm{O}$ & $€ 1.00$ for sure \\
\hline & $\mathrm{O}$ & $\mathrm{O}$ & $€ 1.50$ for sure \\
\hline & $\mathrm{O}$ & $\mathrm{O}$ & $€ 2.00$ for sure \\
\hline & $\mathrm{O}$ & $\mathrm{O}$ & $€ 2.50$ for sure \\
\hline & $\mathrm{O}$ & $\mathrm{O}$ & $€ 3.00$ for sure \\
\hline & $\mathrm{O}$ & $\mathrm{O}$ & $€ 3.50$ for sure \\
\hline & $\mathrm{O}$ & $\mathrm{O}$ & $€ 4.00$ for sure \\
\hline & $\mathrm{O}$ & $\mathrm{O}$ & $€ 4.50$ for sure \\
\hline & $\mathrm{O}$ & $\mathrm{O}$ & $€ 5.00$ for sure \\
\hline & $\mathrm{O}$ & $\mathrm{O}$ & $€ 5.50$ for sure \\
\hline & $\mathrm{O}$ & $\mathrm{O}$ & $€ 6.00$ for sure \\
\hline & $\mathrm{O}$ & $\mathrm{O}$ & $€ 6.50$ for sure \\
\hline Win $\boldsymbol{\epsilon} \mathbf{2 0}$ if one of the following balls is extracted: & $\mathrm{O}$ & $\mathrm{O}$ & $€ 7.00$ for sure \\
\hline 1 & $\mathrm{O}$ & $\mathrm{O}$ & $€ 7.50$ for sure \\
\hline 13 & $\mathrm{O}$ & $\mathrm{O}$ & $€ 8.00$ for sure \\
\hline Win $€ \mathbf{0}$ if one of the following balls is extracted: & $\mathrm{O}$ & $\mathrm{O}$ & $€ 8.50$ for sure \\
\hline & $\mathrm{O}$ & $\mathrm{O}$ & $€ 9.00$ for sure \\
\hline & $\mathrm{O}$ & $\mathrm{O}$ & $€ 9.50$ for sure \\
\hline & $\mathrm{O}$ & $\mathrm{O}$ & $€ 10.00$ for sure \\
\hline & $\mathrm{O}$ & $\mathrm{O}$ & $€ 10.50$ for sure \\
\hline & $\mathrm{O}$ & $\mathrm{O}$ & $€ 11.00$ for sure \\
\hline & $\mathrm{O}$ & $\mathrm{O}$ & $€ 11.50$ for sure \\
\hline & $\mathrm{O}$ & $\mathrm{O}$ & $€ 12.00$ for sure \\
\hline & $\mathrm{O}$ & $\mathrm{O}$ & $€ 12.50$ for sure \\
\hline & $\mathrm{O}$ & $\mathrm{O}$ & $€ 13.00$ for sure \\
\hline & $\mathrm{O}$ & $\mathrm{O}$ & $€ 13.50$ for sure \\
\hline & $\mathrm{O}$ & $\mathrm{O}$ & $€ 14.00$ for sure \\
\hline & $\mathrm{O}$ & $\mathrm{O}$ & $€ 14.50$ for sure \\
\hline & $\mathrm{O}$ & $\mathrm{O}$ & $€ 15.00$ for sure \\
\hline & $\mathrm{O}$ & $\mathrm{O}$ & $€ 15.50$ for sure \\
\hline & $\mathrm{O}$ & $\mathrm{O}$ & $€ 16.00$ for sure \\
\hline & $\mathrm{O}$ & $\mathrm{O}$ & $€ 16.50$ for sure \\
\hline & $\mathrm{O}$ & $\mathrm{O}$ & $€ 17.00$ for sure \\
\hline & $\mathrm{O}$ & $\mathrm{O}$ & $€ 17.50$ for sure \\
\hline & $\mathrm{O}$ & $\mathrm{O}$ & $€ 18.00$ for sure \\
\hline & $\mathrm{O}$ & $\mathrm{O}$ & $€ 18.50$ for sure \\
\hline & $\mathrm{O}$ & $\mathrm{O}$ & $€ 19.00$ for sure \\
\hline & $\mathrm{O}$ & $\mathrm{O}$ & $€ 19.50$ for sure \\
\hline
\end{tabular}




\section{Decision 8}

\begin{tabular}{|c|c|c|c|}
\hline & Lottery & Sur & \\
\hline & $\mathrm{O}$ & $\mathrm{O}$ & $€ 5.50$ for sure \\
\hline & $\mathrm{O}$ & $\mathrm{O}$ & $€ 6.00$ for sure \\
\hline & $\mathrm{O}$ & $\mathrm{O}$ & $€ 6.50$ for sure \\
\hline & $\mathrm{O}$ & $\mathrm{O}$ & $€ 7.00$ for sure \\
\hline & $\mathrm{O}$ & $\mathrm{O}$ & $€ 7.50$ for sure \\
\hline & $\mathrm{O}$ & $\mathrm{O}$ & $€ 8.00$ for sure \\
\hline & $\mathrm{O}$ & $\mathrm{O}$ & $€ 8.50$ for sure \\
\hline & $\mathrm{O}$ & $\mathrm{O}$ & $€ 9.00$ for sure \\
\hline & $\mathrm{O}$ & $\mathrm{O}$ & $€ 9.50$ for sure \\
\hline & $\mathrm{O}$ & $\mathrm{O}$ & $€ 10.00$ for sure \\
\hline & $\mathrm{O}$ & $\mathrm{O}$ & $€ 10.50$ for sure \\
\hline & $\mathrm{O}$ & $\mathrm{O}$ & $€ 11.00$ for sure \\
\hline & $\mathrm{O}$ & $\mathrm{O}$ & $€ 11.50$ for sure \\
\hline Win $\boldsymbol{\epsilon} \mathbf{2 0}$ if one of the following balls is extracted: & $\mathrm{O}$ & $\mathrm{O}$ & $€ 12.00$ for sure \\
\hline 1 & $\mathrm{O}$ & $\mathrm{O}$ & $€ 12.50$ for sure \\
\hline & $\mathrm{O}$ & $\mathrm{O}$ & $€ 13.00$ for sure \\
\hline Win $€ \mathbf{5}$ if one of the following balls is extracted: & $\mathrm{O}$ & $\mathrm{O}$ & $€ 13.50$ for sure \\
\hline & $\mathrm{O}$ & $\mathrm{O}$ & $€ 14.00$ for sure \\
\hline & $\mathrm{O}$ & $\mathrm{O}$ & $€ 14.50$ for sure \\
\hline & $\mathrm{O}$ & $\mathrm{O}$ & $€ 15.00$ for sure \\
\hline & $\mathrm{O}$ & $\mathrm{O}$ & $€ 15.50$ for sure \\
\hline & $\mathrm{O}$ & $\mathrm{O}$ & $€ 16.00$ for sure \\
\hline & $\mathrm{O}$ & $\mathrm{O}$ & $€ 16.50$ for sure \\
\hline & $\mathrm{O}$ & $\mathrm{O}$ & $€ 17.00$ for sure \\
\hline & $\mathrm{O}$ & $\mathrm{O}$ & $€ 17.50$ for sure \\
\hline & $\mathrm{O}$ & $\mathrm{O}$ & $€ 18.00$ for sure \\
\hline & $\mathrm{O}$ & $\mathrm{O}$ & $€ 18.50$ for sure \\
\hline & $\mathrm{O}$ & $\mathrm{O}$ & $€ 19.00$ for sure \\
\hline & $\mathrm{O}$ & $\mathrm{O}$ & $€ 19.50$ for sure \\
\hline
\end{tabular}




\section{Decision 9}

\begin{tabular}{|c|c|c|c|}
\hline & Lottery & Sul & \\
\hline & $\mathrm{O}$ & $\mathrm{O}$ & $€ 0.50$ for sure \\
\hline & $\mathrm{O}$ & $\mathrm{O}$ & $€ 1.00$ for sure \\
\hline & $\mathrm{O}$ & $\mathrm{O}$ & $€ 1.50$ for sure \\
\hline & $\mathrm{O}$ & $\mathrm{O}$ & $€ 2.00$ for sure \\
\hline & $\mathrm{O}$ & $\mathrm{O}$ & $€ 2.50$ for sure \\
\hline & $\mathrm{O}$ & $\mathrm{O}$ & $€ 3.00$ for sure \\
\hline & $\mathrm{O}$ & $\mathrm{O}$ & $€ 3.50$ for sure \\
\hline & $\mathrm{O}$ & $\mathrm{O}$ & $€ 4.00$ for sure \\
\hline & $\mathrm{O}$ & $\mathrm{O}$ & $€ 4.50$ for sure \\
\hline & $\mathrm{O}$ & $\mathrm{O}$ & $€ 5.00$ for sure \\
\hline & $\mathrm{O}$ & $\mathrm{O}$ & $€ 5.50$ for sure \\
\hline & $\mathrm{O}$ & $\mathrm{O}$ & $€ 6.00$ for sure \\
\hline & $\mathrm{O}$ & $\mathrm{O}$ & $€ 6.50$ for sure \\
\hline Win $€ 20$ if one of the following balls is extracted: & $\mathrm{O}$ & $\mathrm{O}$ & $€ 7.00$ for sure \\
\hline & $\mathrm{O}$ & $\mathrm{O}$ & $€ 7.50$ for sure \\
\hline & $\mathrm{O}$ & $\mathrm{O}$ & $€ 8.00$ for sure \\
\hline Win $€ \mathbf{0}$ if one of the following balls is extracted: & $\mathrm{O}$ & $\mathrm{O}$ & $€ 8.50$ for sure \\
\hline & $\mathrm{O}$ & $\mathrm{O}$ & $€ 9.00$ for sure \\
\hline & $\mathrm{O}$ & $\mathrm{O}$ & $€ 9.50$ for sure \\
\hline & $\mathrm{O}$ & $\mathrm{O}$ & $€ 10.00$ for sure \\
\hline & $\mathrm{O}$ & $\mathrm{O}$ & $€ 10.50$ for sure \\
\hline & $\mathrm{O}$ & $\mathrm{O}$ & $€ 11.00$ for sure \\
\hline & $\mathrm{O}$ & $\mathrm{O}$ & $€ 11.50$ for sure \\
\hline & $\mathrm{O}$ & $\mathrm{O}$ & $€ 12.00$ for sure \\
\hline & $\mathrm{O}$ & $\mathrm{O}$ & $€ 12.50$ for sure \\
\hline & $\mathrm{O}$ & $\mathrm{O}$ & $€ 13.00$ for sure \\
\hline & $\mathrm{O}$ & $\mathrm{O}$ & $€ 13.50$ for sure \\
\hline & $\mathrm{O}$ & $\mathrm{O}$ & $€ 14.00$ for sure \\
\hline & $\mathrm{O}$ & $\mathrm{O}$ & $€ 14.50$ for sure \\
\hline & $\mathrm{O}$ & $\mathrm{O}$ & $€ 15.00$ for sure \\
\hline & $\mathrm{O}$ & $\mathrm{O}$ & $€ 15.50$ for sure \\
\hline & $\mathrm{O}$ & $\mathrm{O}$ & $€ 16.00$ for sure \\
\hline & $\mathrm{O}$ & $\mathrm{O}$ & $€ 16.50$ for sure \\
\hline & $\mathrm{O}$ & $\mathrm{O}$ & $€ 17.00$ for sure \\
\hline & $\mathrm{O}$ & $\mathrm{O}$ & $€ 17.50$ for sure \\
\hline & $\mathrm{O}$ & $\mathrm{O}$ & $€ 18.00$ for sure \\
\hline & $\mathrm{O}$ & $\mathrm{O}$ & $€ 18.50$ for sure \\
\hline & $\mathrm{O}$ & $\mathrm{O}$ & $€ 19.00$ for sure \\
\hline & $\mathrm{O}$ & $\mathrm{O}$ & $€ 19.50$ for sure \\
\hline
\end{tabular}




\section{Decision 10}

\begin{tabular}{|c|c|c|c|}
\hline & Lottery & Sur & \\
\hline & $\mathrm{O}$ & $\mathrm{O}$ & $€ 0.50$ for sure \\
\hline & $\mathrm{O}$ & $\mathrm{O}$ & $€ 1.00$ for sure \\
\hline & $\mathrm{O}$ & $\mathrm{O}$ & $€ 1.50$ for sure \\
\hline & $\mathrm{O}$ & $\mathrm{O}$ & $€ 2.00$ for sure \\
\hline & $\mathrm{O}$ & $\mathrm{O}$ & $€ 2.50$ for sure \\
\hline & $\mathrm{O}$ & $\mathrm{O}$ & $€ 3.00$ for sure \\
\hline & $\mathrm{O}$ & $\mathrm{O}$ & $€ 3.50$ for sure \\
\hline & $\mathrm{O}$ & $\mathrm{O}$ & $€ 4.00$ for sure \\
\hline AITI & $\mathrm{O}$ & $\mathrm{O}$ & $€ 4.50$ for sure \\
\hline & $\mathrm{O}$ & $\mathrm{O}$ & $€ 5.00$ for sure \\
\hline & $\mathrm{O}$ & $\mathrm{O}$ & $€ 5.50$ for sure \\
\hline & $\mathrm{O}$ & $\mathrm{O}$ & $€ 6.00$ for sure \\
\hline & $\mathrm{O}$ & $\mathrm{O}$ & $€ 6.50$ for sure \\
\hline Win $\boldsymbol{\epsilon} \mathbf{2 0}$ if one of the following balls is extracted: & $\mathrm{O}$ & $\mathrm{O}$ & $€ 7.00$ for sure \\
\hline & $\mathrm{O}$ & $\mathrm{O}$ & $€ 7.50$ for sure \\
\hline (3) & $\mathrm{O}$ & $\mathrm{O}$ & $€ 8.00$ for sure \\
\hline Win $€ \mathbf{0}$ if one of the following balls is extracted: & $\mathrm{O}$ & $\mathrm{O}$ & $€ 8.50$ for sure \\
\hline & $\mathrm{O}$ & $\mathrm{O}$ & $€ 9.00$ for sure \\
\hline & $\mathrm{O}$ & $\mathrm{O}$ & $€ 9.50$ for sure \\
\hline & $\mathrm{O}$ & $\mathrm{O}$ & $€ 10.00$ for sure \\
\hline & $\mathrm{O}$ & $\mathrm{O}$ & $€ 10.50$ for sure \\
\hline & $\mathrm{O}$ & $\mathrm{O}$ & $€ 11.00$ for sure \\
\hline & $\mathrm{O}$ & $\mathrm{O}$ & $€ 11.50$ for sure \\
\hline & $\mathrm{O}$ & $\mathrm{O}$ & $€ 12.00$ for sure \\
\hline & $\mathrm{O}$ & $\mathrm{O}$ & $€ 12.50$ for sure \\
\hline & $\mathrm{O}$ & $\mathrm{O}$ & $€ 13.00$ for sure \\
\hline & $\mathrm{O}$ & $\mathrm{O}$ & $€ 13.50$ for sure \\
\hline & $\mathrm{O}$ & $\mathrm{O}$ & $€ 14.00$ for sure \\
\hline & $\mathrm{O}$ & $\mathrm{O}$ & $€ 14.50$ for sure \\
\hline & $\mathrm{O}$ & $\mathrm{O}$ & $€ 15.00$ for sure \\
\hline & $\mathrm{O}$ & $\mathrm{O}$ & $€ 15.50$ for sure \\
\hline & $\mathrm{O}$ & $\mathrm{O}$ & $€ 16.00$ for sure \\
\hline & $\mathrm{O}$ & $\mathrm{O}$ & $€ 16.50$ for sure \\
\hline & $\mathrm{O}$ & $\mathrm{O}$ & $€ 17.00$ for sure \\
\hline & $\mathrm{O}$ & $\mathrm{O}$ & $€ 17.50$ for sure \\
\hline & $\mathrm{O}$ & $\mathrm{O}$ & $€ 18.00$ for sure \\
\hline & $\mathrm{O}$ & $\mathrm{O}$ & $€ 18.50$ for sure \\
\hline & $\mathrm{O}$ & $\mathrm{O}$ & $€ 19.00$ for sure \\
\hline & $\mathrm{O}$ & $\mathrm{O}$ & $€ 19.50$ for sure \\
\hline
\end{tabular}




\section{Decision 11}

\begin{tabular}{|c|c|c|c|}
\hline & Lottery & $\mathrm{Su}$ & \\
\hline & $\mathrm{O}$ & $\mathrm{O}$ & $€ 0.50$ for sure \\
\hline & $\mathrm{O}$ & $\mathrm{O}$ & $€ 1.00$ for sure \\
\hline & $\mathrm{O}$ & $\mathrm{O}$ & $€ 1.50$ for sure \\
\hline & $\mathrm{O}$ & $\mathrm{O}$ & $€ 2.00$ for sure \\
\hline & $\mathrm{O}$ & $\mathrm{O}$ & $€ 2.50$ for sure \\
\hline & $\mathrm{O}$ & $\mathrm{O}$ & $€ 3.00$ for sure \\
\hline & $\mathrm{O}$ & $\mathrm{O}$ & $€ 3.50$ for sure \\
\hline & $\mathrm{O}$ & $\mathrm{O}$ & $€ 4.00$ for sure \\
\hline AII & $\mathrm{O}$ & $\mathrm{O}$ & $€ 4.50$ for sure \\
\hline & $\mathrm{O}$ & $\mathrm{O}$ & $€ 5.00$ for sure \\
\hline & $\mathrm{O}$ & $\mathrm{O}$ & $€ 5.50$ for sure \\
\hline & $\mathrm{O}$ & $\mathrm{O}$ & $€ 6.00$ for sure \\
\hline & $\mathrm{O}$ & $\mathrm{O}$ & $€ 6.50$ for sure \\
\hline Win $€ \mathbf{2 0}$ if one of the following balls is extracted: & $\mathrm{O}$ & $\mathrm{O}$ & $€ 7.00$ for sure \\
\hline & $\mathrm{O}$ & $\mathrm{O}$ & $€ 7.50$ for sure \\
\hline & $\mathrm{O}$ & $\mathrm{O}$ & $€ 8.00$ for sure \\
\hline Win $\boldsymbol{€} \mathbf{0}$ if one of the following balls is extracted: & $\mathrm{O}$ & $\mathrm{O}$ & $€ 8.50$ for sure \\
\hline & $\mathrm{O}$ & $\mathrm{O}$ & $€ 9.00$ for sure \\
\hline & $\mathrm{O}$ & $\mathrm{O}$ & $€ 9.50$ for sure \\
\hline & $\mathrm{O}$ & $\mathrm{O}$ & $€ 10.00$ for sure \\
\hline & $\mathrm{O}$ & $\mathrm{O}$ & $€ 10.50$ for sure \\
\hline & $\mathrm{O}$ & $\mathrm{O}$ & $€ 11.00$ for sure \\
\hline & $\mathrm{O}$ & $\mathrm{O}$ & $€ 11.50$ for sure \\
\hline & $\mathrm{O}$ & $\mathrm{O}$ & $€ 12.00$ for sure \\
\hline & $\mathrm{O}$ & $\mathrm{O}$ & $€ 12.50$ for sure \\
\hline & $\mathrm{O}$ & $\mathrm{O}$ & $€ 13.00$ for sure \\
\hline & $\mathrm{O}$ & $\mathrm{O}$ & $€ 13.50$ for sure \\
\hline & $\mathrm{O}$ & $\mathrm{O}$ & $€ 14.00$ for sure \\
\hline & $\mathrm{O}$ & $\mathrm{O}$ & $€ 14.50$ for sure \\
\hline & $\mathrm{O}$ & $\mathrm{O}$ & $€ 15.00$ for sure \\
\hline & $\mathrm{O}$ & $\mathrm{O}$ & $€ 15.50$ for sure \\
\hline & $\mathrm{O}$ & $\mathrm{O}$ & $€ 16.00$ for sure \\
\hline & $\mathrm{O}$ & $\mathrm{O}$ & $€ 16.50$ for sure \\
\hline & $\mathrm{O}$ & $\mathrm{O}$ & $€ 17.00$ for sure \\
\hline & $\mathrm{O}$ & $\mathrm{O}$ & $€ 17.50$ for sure \\
\hline & $\mathrm{O}$ & $\mathrm{O}$ & $€ 18.00$ for sure \\
\hline & $\mathrm{O}$ & $\mathrm{O}$ & $€ 18.50$ for sure \\
\hline & $\mathrm{O}$ & $\mathrm{O}$ & $€ 19.00$ for sure \\
\hline & $\mathrm{O}$ & $\mathrm{O}$ & $€ 19.50$ for sure \\
\hline
\end{tabular}




\section{Decision 12}

\begin{tabular}{|c|c|c|c|}
\hline & Lottery & $\mathrm{Su}$ & \\
\hline & $\mathrm{O}$ & $\mathrm{O}$ & $€ 0.50$ for sure \\
\hline & $\mathrm{O}$ & $\mathrm{O}$ & $€ 1.00$ for sure \\
\hline & $\mathrm{O}$ & $\mathrm{O}$ & $€ 1.50$ for sure \\
\hline & $\mathrm{O}$ & $\mathrm{O}$ & $€ 2.00$ for sure \\
\hline & $\mathrm{O}$ & $\mathrm{O}$ & $€ 2.50$ for sure \\
\hline & $\mathrm{O}$ & $\mathrm{O}$ & $€ 3.00$ for sure \\
\hline & $\mathrm{O}$ & $\mathrm{O}$ & $€ 3.50$ for sure \\
\hline & $\mathrm{O}$ & $\mathrm{O}$ & $€ 4.00$ for sure \\
\hline AII & $\mathrm{O}$ & $\mathrm{O}$ & $€ 4.50$ for sure \\
\hline & $\mathrm{O}$ & $\mathrm{O}$ & $€ 5.00$ for sure \\
\hline & $\mathrm{O}$ & $\mathrm{O}$ & $€ 5.50$ for sure \\
\hline & $\mathrm{O}$ & $\mathrm{O}$ & $€ 6.00$ for sure \\
\hline & $\mathrm{O}$ & $\mathrm{O}$ & $€ 6.50$ for sure \\
\hline Win $€ \mathbf{2 0}$ if one of the following balls is extracted: & $\mathrm{O}$ & $\mathrm{O}$ & $€ 7.00$ for sure \\
\hline & $\mathrm{O}$ & $\mathrm{O}$ & $€ 7.50$ for sure \\
\hline & $\mathrm{O}$ & $\mathrm{O}$ & $€ 8.00$ for sure \\
\hline Win $\boldsymbol{€} \mathbf{0}$ if one of the following balls is extracted: & $\mathrm{O}$ & $\mathrm{O}$ & $€ 8.50$ for sure \\
\hline & $\mathrm{O}$ & $\mathrm{O}$ & $€ 9.00$ for sure \\
\hline & $\mathrm{O}$ & $\mathrm{O}$ & $€ 9.50$ for sure \\
\hline & $\mathrm{O}$ & $\mathrm{O}$ & $€ 10.00$ for sure \\
\hline & $\mathrm{O}$ & $\mathrm{O}$ & $€ 10.50$ for sure \\
\hline & $\mathrm{O}$ & $\mathrm{O}$ & $€ 11.00$ for sure \\
\hline & $\mathrm{O}$ & $\mathrm{O}$ & $€ 11.50$ for sure \\
\hline & $\mathrm{O}$ & $\mathrm{O}$ & $€ 12.00$ for sure \\
\hline & $\mathrm{O}$ & $\mathrm{O}$ & $€ 12.50$ for sure \\
\hline & $\mathrm{O}$ & $\mathrm{O}$ & $€ 13.00$ for sure \\
\hline & $\mathrm{O}$ & $\mathrm{O}$ & $€ 13.50$ for sure \\
\hline & $\mathrm{O}$ & $\mathrm{O}$ & $€ 14.00$ for sure \\
\hline & $\mathrm{O}$ & $\mathrm{O}$ & $€ 14.50$ for sure \\
\hline & $\mathrm{O}$ & $\mathrm{O}$ & $€ 15.00$ for sure \\
\hline & $\mathrm{O}$ & $\mathrm{O}$ & $€ 15.50$ for sure \\
\hline & $\mathrm{O}$ & $\mathrm{O}$ & $€ 16.00$ for sure \\
\hline & $\mathrm{O}$ & $\mathrm{O}$ & $€ 16.50$ for sure \\
\hline & $\mathrm{O}$ & $\mathrm{O}$ & $€ 17.00$ for sure \\
\hline & $\mathrm{O}$ & $\mathrm{O}$ & $€ 17.50$ for sure \\
\hline & $\mathrm{O}$ & $\mathrm{O}$ & $€ 18.00$ for sure \\
\hline & $\mathrm{O}$ & $\mathrm{O}$ & $€ 18.50$ for sure \\
\hline & $\mathrm{O}$ & $\mathrm{O}$ & $€ 19.00$ for sure \\
\hline & $\mathrm{O}$ & $\mathrm{O}$ & $€ 19.50$ for sure \\
\hline
\end{tabular}




\section{Decision 13}

\begin{tabular}{|c|c|c|c|}
\hline & Lottery & $\mathrm{Su}$ & \\
\hline & $\mathrm{O}$ & $\mathrm{O}$ & $€ 0.50$ for sure \\
\hline & $\mathrm{O}$ & $\mathrm{O}$ & $€ 1.00$ for sure \\
\hline & $\mathrm{O}$ & $\mathrm{O}$ & $€ 1.50$ for sure \\
\hline & $\mathrm{O}$ & $\mathrm{O}$ & $€ 2.00$ for sure \\
\hline & $\mathrm{O}$ & $\mathrm{O}$ & $€ 2.50$ for sure \\
\hline & $\mathrm{O}$ & $\mathrm{O}$ & $€ 3.00$ for sure \\
\hline & $\mathrm{O}$ & $\mathrm{O}$ & $€ 3.50$ for sure \\
\hline & $\mathrm{O}$ & $\mathrm{O}$ & $€ 4.00$ for sure \\
\hline AII & $\mathrm{O}$ & $\mathrm{O}$ & $€ 4.50$ for sure \\
\hline & $\mathrm{O}$ & $\mathrm{O}$ & $€ 5.00$ for sure \\
\hline & $\mathrm{O}$ & $\mathrm{O}$ & $€ 5.50$ for sure \\
\hline & $\mathrm{O}$ & $\mathrm{O}$ & $€ 6.00$ for sure \\
\hline & $\mathrm{O}$ & $\mathrm{O}$ & $€ 6.50$ for sure \\
\hline Win $€ \mathbf{2 0}$ if one of the following balls is extracted: & $\mathrm{O}$ & $\mathrm{O}$ & $€ 7.00$ for sure \\
\hline & $\mathrm{O}$ & $\mathrm{O}$ & $€ 7.50$ for sure \\
\hline & $\mathrm{O}$ & $\mathrm{O}$ & $€ 8.00$ for sure \\
\hline Win $\boldsymbol{€} \mathbf{0}$ if one of the following balls is extracted: & $\mathrm{O}$ & $\mathrm{O}$ & $€ 8.50$ for sure \\
\hline & $\mathrm{O}$ & $\mathrm{O}$ & $€ 9.00$ for sure \\
\hline & $\mathrm{O}$ & $\mathrm{O}$ & $€ 9.50$ for sure \\
\hline & $\mathrm{O}$ & $\mathrm{O}$ & $€ 10.00$ for sure \\
\hline & $\mathrm{O}$ & $\mathrm{O}$ & $€ 10.50$ for sure \\
\hline & $\mathrm{O}$ & $\mathrm{O}$ & $€ 11.00$ for sure \\
\hline & $\mathrm{O}$ & $\mathrm{O}$ & $€ 11.50$ for sure \\
\hline & $\mathrm{O}$ & $\mathrm{O}$ & $€ 12.00$ for sure \\
\hline & $\mathrm{O}$ & $\mathrm{O}$ & $€ 12.50$ for sure \\
\hline & $\mathrm{O}$ & $\mathrm{O}$ & $€ 13.00$ for sure \\
\hline & $\mathrm{O}$ & $\mathrm{O}$ & $€ 13.50$ for sure \\
\hline & $\mathrm{O}$ & $\mathrm{O}$ & $€ 14.00$ for sure \\
\hline & $\mathrm{O}$ & $\mathrm{O}$ & $€ 14.50$ for sure \\
\hline & $\mathrm{O}$ & $\mathrm{O}$ & $€ 15.00$ for sure \\
\hline & $\mathrm{O}$ & $\mathrm{O}$ & $€ 15.50$ for sure \\
\hline & $\mathrm{O}$ & $\mathrm{O}$ & $€ 16.00$ for sure \\
\hline & $\mathrm{O}$ & $\mathrm{O}$ & $€ 16.50$ for sure \\
\hline & $\mathrm{O}$ & $\mathrm{O}$ & $€ 17.00$ for sure \\
\hline & $\mathrm{O}$ & $\mathrm{O}$ & $€ 17.50$ for sure \\
\hline & $\mathrm{O}$ & $\mathrm{O}$ & $€ 18.00$ for sure \\
\hline & $\mathrm{O}$ & $\mathrm{O}$ & $€ 18.50$ for sure \\
\hline & $\mathrm{O}$ & $\mathrm{O}$ & $€ 19.00$ for sure \\
\hline & $\mathrm{O}$ & $\mathrm{O}$ & $€ 19.50$ for sure \\
\hline
\end{tabular}




\section{Decision 14}

\begin{tabular}{|c|c|c|c|}
\hline & Lottery & $\mathrm{Su}$ & \\
\hline & $\mathrm{O}$ & $\mathrm{O}$ & $€ 5.50$ for sure \\
\hline & $\mathrm{O}$ & $\mathrm{O}$ & $€ 6.00$ for sure \\
\hline & $\mathrm{O}$ & $\mathrm{O}$ & $€ 6.50$ for sure \\
\hline & $\mathrm{O}$ & $\mathrm{O}$ & $€ 7.00$ for sure \\
\hline & $\mathrm{O}$ & $\mathrm{O}$ & $€ 7.50$ for sure \\
\hline & $\mathrm{O}$ & $\mathrm{O}$ & $€ 8.00$ for sure \\
\hline & $\mathrm{O}$ & $\mathrm{O}$ & $€ 8.50$ for sure \\
\hline & $\mathrm{O}$ & $\mathrm{O}$ & $€ 9.00$ for sure \\
\hline AIIT & $\mathrm{O}$ & $\mathrm{O}$ & $€ 9.50$ for sure \\
\hline & $\mathrm{O}$ & $\mathrm{O}$ & $€ 10.00$ for sure \\
\hline & $\mathrm{O}$ & $\mathrm{O}$ & $€ 10.50$ for sure \\
\hline & $\mathrm{O}$ & $\mathrm{O}$ & $€ 11.00$ for sure \\
\hline & $\mathrm{O}$ & $\mathrm{O}$ & $€ 11.50$ for sure \\
\hline Win $€ \mathbf{2 0}$ if one of the following balls is extracted: & $\mathrm{O}$ & $\mathrm{O}$ & $€ 12.00$ for sure \\
\hline & $\mathrm{O}$ & $\mathrm{O}$ & $€ 12.50$ for sure \\
\hline & $\mathrm{O}$ & $\mathrm{O}$ & $€ 13.00$ for sure \\
\hline Win $\boldsymbol{\epsilon} \mathbf{5}$ if one of the following balls is extracted: & $\mathrm{O}$ & $\mathrm{O}$ & $€ 13.50$ for sure \\
\hline & $\mathrm{O}$ & $\mathrm{O}$ & $€ 14.00$ for sure \\
\hline & $\mathrm{O}$ & $\mathrm{O}$ & $€ 14.50$ for sure \\
\hline & $\mathrm{O}$ & $\mathrm{O}$ & $€ 15.00$ for sure \\
\hline & $\mathrm{O}$ & $\mathrm{O}$ & $€ 15.50$ for sure \\
\hline & $\mathrm{O}$ & $\mathrm{O}$ & $€ 16.00$ for sure \\
\hline & $\mathrm{O}$ & $\mathrm{O}$ & $€ 16.50$ for sure \\
\hline & $\mathrm{O}$ & $\mathrm{O}$ & $€ 17.00$ for sure \\
\hline & $\mathrm{O}$ & $\mathrm{O}$ & $€ 17.50$ for sure \\
\hline & $\mathrm{O}$ & $\mathrm{O}$ & $€ 18.00$ for sure \\
\hline & $\mathrm{O}$ & $\mathrm{O}$ & $€ 18.50$ for sure \\
\hline & $\mathrm{O}$ & $\mathrm{O}$ & $€ 19.00$ for sure \\
\hline & $\mathrm{O}$ & $\mathrm{O}$ & $€ 19.50$ for sure \\
\hline
\end{tabular}




\section{Decision 15}

\begin{tabular}{|c|c|c|c|}
\hline \multicolumn{2}{|c|}{ Lottery } & \multicolumn{2}{|c|}{ Sure } \\
\hline \multirow{13}{*}{ 101010 } & $\mathrm{O}$ & $\mathrm{O}$ & $€ 0.50$ for sure \\
\hline & $\mathrm{O}$ & $\mathrm{O}$ & $€ 1.00$ for sure \\
\hline & $\mathrm{O}$ & $\mathrm{O}$ & $€ 1.50$ for sure \\
\hline & $\mathrm{O}$ & $\mathrm{O}$ & $€ 2.00$ for sure \\
\hline & $\mathrm{O}$ & $\mathrm{O}$ & $€ 2.50$ for sure \\
\hline & $\mathrm{O}$ & $\mathrm{O}$ & $€ 3.00$ for sure \\
\hline & $\mathrm{O}$ & $\mathrm{O}$ & $€ 3.50$ for sure \\
\hline & $\mathrm{O}$ & $\mathrm{O}$ & $€ 4.00$ for sure \\
\hline & $\mathrm{O}$ & $\mathrm{O}$ & $€ 4.50$ for sure \\
\hline & $\mathrm{O}$ & $\mathrm{O}$ & $€ 5.00$ for sure \\
\hline & $\mathrm{O}$ & $\mathrm{O}$ & $€ 5.50$ for sure \\
\hline & $\mathrm{O}$ & $\mathrm{O}$ & $€ 6.00$ for sure \\
\hline & $\mathrm{O}$ & $\mathrm{O}$ & $€ 6.50$ for sure \\
\hline Win $€ 20$ if one of the following balls is extracted: & $\mathrm{O}$ & $\mathrm{O}$ & $€ 7.00$ for sure \\
\hline & $\mathrm{O}$ & $\mathrm{O}$ & $€ 7.50$ for sure \\
\hline & $\mathrm{O}$ & $\mathrm{O}$ & $€ 8.00$ for sure \\
\hline Win $€ \mathbf{0}$ if one of the following balls is extracted: & $\mathrm{O}$ & $\mathrm{O}$ & $€ 8.50$ for sure \\
\hline & $\mathrm{O}$ & $\mathrm{O}$ & $€ 9.00$ for sure \\
\hline & $\mathrm{O}$ & $\mathrm{O}$ & $€ 9.50$ for sure \\
\hline & $\mathrm{O}$ & $\mathrm{O}$ & $€ 10.00$ for sure \\
\hline & $\mathrm{O}$ & $\mathrm{O}$ & $€ 10.50$ for sure \\
\hline & $\mathrm{O}$ & $\mathrm{O}$ & $€ 11.00$ for sure \\
\hline & $\mathrm{O}$ & $\mathrm{O}$ & $€ 11.50$ for sure \\
\hline & $\mathrm{O}$ & $\mathrm{O}$ & $€ 12.00$ for sure \\
\hline & $\mathrm{O}$ & $\mathrm{O}$ & $€ 12.50$ for sure \\
\hline & $\mathrm{O}$ & $\mathrm{O}$ & $€ 13.00$ for sure \\
\hline & $\mathrm{O}$ & $\mathrm{O}$ & $€ 13.50$ for sure \\
\hline & $\mathrm{O}$ & $\mathrm{O}$ & $€ 14.00$ for sure \\
\hline & $\mathrm{O}$ & $\mathrm{O}$ & $€ 14.50$ for sure \\
\hline & $\mathrm{O}$ & $\mathrm{O}$ & $€ 15.00$ for sure \\
\hline & $\mathrm{O}$ & $\mathrm{O}$ & $€ 15.50$ for sure \\
\hline & $\mathrm{O}$ & $\mathrm{O}$ & $€ 16.00$ for sure \\
\hline & $\mathrm{O}$ & $\mathrm{O}$ & $€ 16.50$ for sure \\
\hline & $\mathrm{O}$ & $\mathrm{O}$ & $€ 17.00$ for sure \\
\hline & $\mathrm{O}$ & $\mathrm{O}$ & $€ 17.50$ for sure \\
\hline & $\mathrm{O}$ & $\mathrm{O}$ & $€ 18.00$ for sure \\
\hline & $\mathrm{O}$ & $\mathrm{O}$ & $€ 18.50$ for sure \\
\hline & $\mathrm{O}$ & $\mathrm{O}$ & $€ 19.00$ for sure \\
\hline & $\mathrm{O}$ & $\mathrm{O}$ & $€ 19.50$ for sure \\
\hline
\end{tabular}




\section{Decision 16}

\begin{tabular}{|c|c|c|c|}
\hline \multicolumn{2}{|c|}{ Lottery } & \multicolumn{2}{|c|}{ Sure } \\
\hline \multirow{13}{*}{ 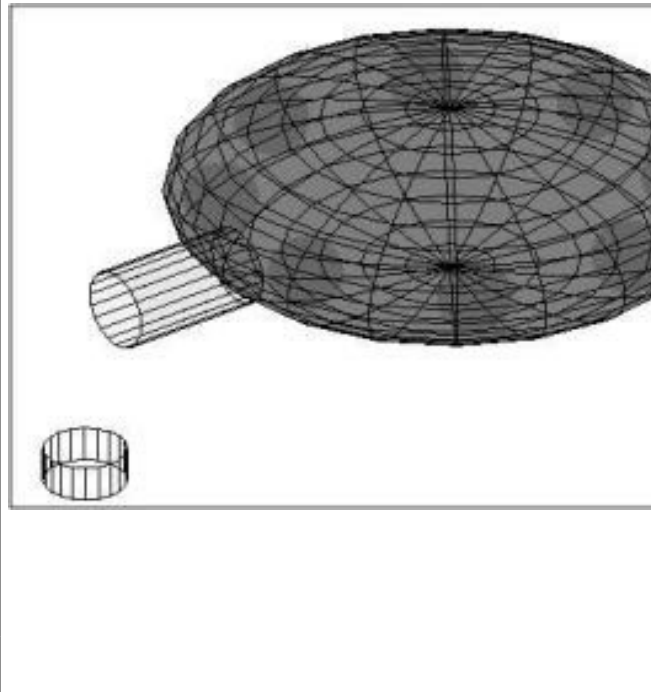 } & $\mathrm{O}$ & $\mathrm{O}$ & $€ 5.50$ for sure \\
\hline & $\mathrm{O}$ & $\mathrm{O}$ & $€ 6.00$ for sure \\
\hline & $\mathrm{O}$ & $\mathrm{O}$ & $€ 6.50$ for sure \\
\hline & $\mathrm{O}$ & $\mathrm{O}$ & $€ 7.00$ for sure \\
\hline & $\mathrm{O}$ & $\mathrm{O}$ & $€ 7.50$ for sure \\
\hline & $\mathrm{O}$ & $\mathrm{O}$ & $€ 8.00$ for sure \\
\hline & $\mathrm{O}$ & $\mathrm{O}$ & $€ 8.50$ for sure \\
\hline & $\mathrm{O}$ & $\mathrm{O}$ & $€ 9.00$ for sure \\
\hline & $\mathrm{O}$ & $\mathrm{O}$ & $€ 9.50$ for sure \\
\hline & $\mathrm{O}$ & $\mathrm{O}$ & $€ 10.00$ for sure \\
\hline & $\mathrm{O}$ & $\mathrm{O}$ & $€ 10.50$ for sure \\
\hline & $\mathrm{O}$ & $\mathrm{O}$ & $€ 11.00$ for sure \\
\hline & $\mathrm{O}$ & $\mathrm{O}$ & $€ 11.50$ for sure \\
\hline Win $€ 20$ if one of the following balls is extracted: & $\mathrm{O}$ & $\mathrm{O}$ & $€ 12.00$ for sure \\
\hline & $\mathrm{O}$ & $\mathrm{O}$ & $€ 12.50$ for sure \\
\hline & $\mathrm{O}$ & $\mathrm{O}$ & $€ 13.00$ for sure \\
\hline Win $\boldsymbol{€} \mathbf{5}$ if one of the following balls is extracted: & $\mathrm{O}$ & $\mathrm{O}$ & $€ 13.50$ for sure \\
\hline & $\mathrm{O}$ & $\mathrm{O}$ & $€ 14.00$ for sure \\
\hline & $\mathrm{O}$ & $\mathrm{O}$ & $€ 14.50$ for sure \\
\hline & $\mathrm{O}$ & $\mathrm{O}$ & $€ 15.00$ for sure \\
\hline & $\mathrm{O}$ & $\mathrm{O}$ & $€ 15.50$ for sure \\
\hline & $\mathrm{O}$ & $\mathrm{O}$ & $€ 16.00$ for sure \\
\hline & $\mathrm{O}$ & $\mathrm{O}$ & $€ 16.50$ for sure \\
\hline & $\mathrm{O}$ & $\mathrm{O}$ & $€ 17.00$ for sure \\
\hline & $\mathrm{O}$ & $\mathrm{O}$ & $€ 17.50$ for sure \\
\hline & $\mathrm{O}$ & $\mathrm{O}$ & $€ 18.00$ for sure \\
\hline & $\mathrm{O}$ & $\mathrm{O}$ & $€ 18.50$ for sure \\
\hline & $\mathrm{O}$ & $\mathrm{O}$ & $€ 19.00$ for sure \\
\hline & $\mathrm{O}$ & $\mathrm{O}$ & $€ 19.50$ for sure \\
\hline & $\mathrm{O}$ & $\mathrm{O}$ & \\
\hline
\end{tabular}




\section{Decision 17}

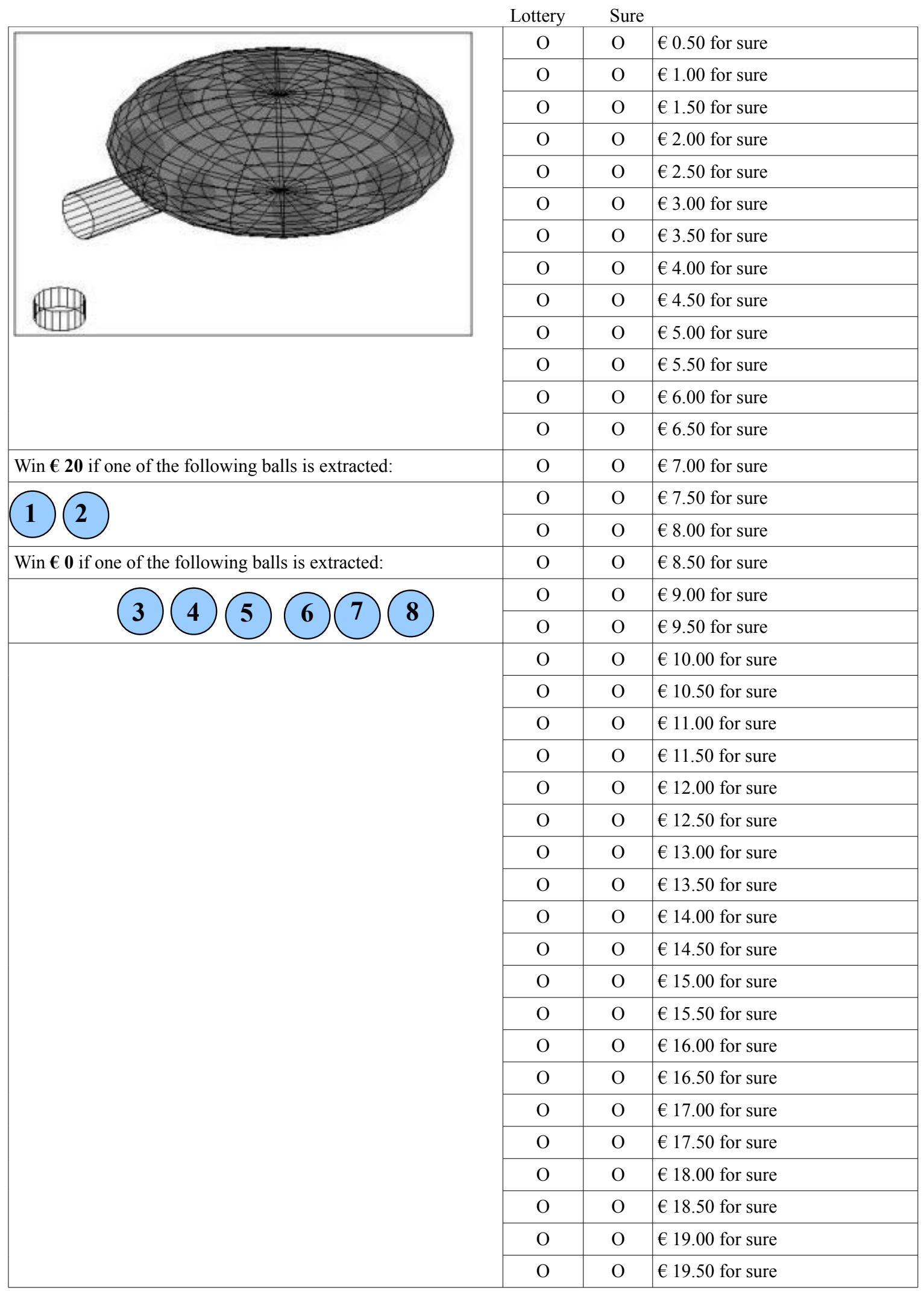




\section{Decision 18}

\begin{tabular}{|c|c|c|c|}
\hline & Lottery & $\mathrm{Su}$ & \\
\hline & $\mathrm{O}$ & $\mathrm{O}$ & $€ 0.50$ for sure \\
\hline & $\mathrm{O}$ & $\mathrm{O}$ & $€ 1.00$ for sure \\
\hline & $\mathrm{O}$ & $\mathrm{O}$ & $€ 1.50$ for sure \\
\hline & $\mathrm{O}$ & $\mathrm{O}$ & $€ 2.00$ for sure \\
\hline & $\mathrm{O}$ & $\mathrm{O}$ & $€ 2.50$ for sure \\
\hline & $\mathrm{O}$ & $\mathrm{O}$ & $€ 3.00$ for sure \\
\hline & $\mathrm{O}$ & $\mathrm{O}$ & $€ 3.50$ for sure \\
\hline & $\mathrm{O}$ & $\mathrm{O}$ & $€ 4.00$ for sure \\
\hline & $\mathrm{O}$ & $\mathrm{O}$ & $€ 4.50$ for sure \\
\hline & $\mathrm{O}$ & $\mathrm{O}$ & $€ 5.00$ for sure \\
\hline & $\mathrm{O}$ & $\mathrm{O}$ & $€ 5.50$ for sure \\
\hline & $\mathrm{O}$ & $\mathrm{O}$ & $€ 6.00$ for sure \\
\hline & $\mathrm{O}$ & $\mathrm{O}$ & $€ 6.50$ for sure \\
\hline Win $€ \mathbf{2 0}$ if one of the following balls is extracted: & $\mathrm{O}$ & $\mathrm{O}$ & $€ 7.00$ for sure \\
\hline & $\mathrm{O}$ & $\mathrm{O}$ & $€ 7.50$ for sure \\
\hline & $\mathrm{O}$ & $\mathrm{O}$ & $€ 8.00$ for sure \\
\hline Win $€ \mathbf{0}$ if one of the following balls is extracted: & $\mathrm{O}$ & $\mathrm{O}$ & $€ 8.50$ for sure \\
\hline & $\mathrm{O}$ & $\mathrm{O}$ & $€ 9.00$ for sure \\
\hline & $\mathrm{O}$ & $\mathrm{O}$ & $€ 9.50$ for sure \\
\hline & $\mathrm{O}$ & $\mathrm{O}$ & $€ 10.00$ for sure \\
\hline & $\mathrm{O}$ & $\mathrm{O}$ & $€ 10.50$ for sure \\
\hline & $\mathrm{O}$ & $\mathrm{O}$ & $€ 11.00$ for sure \\
\hline & $\mathrm{O}$ & $\mathrm{O}$ & $€ 11.50$ for sure \\
\hline & $\mathrm{O}$ & $\mathrm{O}$ & $€ 12.00$ for sure \\
\hline & $\mathrm{O}$ & $\mathrm{O}$ & $€ 12.50$ for sure \\
\hline & $\mathrm{O}$ & $\mathrm{O}$ & $€ 13.00$ for sure \\
\hline & $\mathrm{O}$ & $\mathrm{O}$ & $€ 13.50$ for sure \\
\hline & $\mathrm{O}$ & $\mathrm{O}$ & $€ 14.00$ for sure \\
\hline & $\mathrm{O}$ & $\mathrm{O}$ & $€ 14.50$ for sure \\
\hline & $\mathrm{O}$ & $\mathrm{O}$ & $€ 15.00$ for sure \\
\hline & $\mathrm{O}$ & $\mathrm{O}$ & $€ 15.50$ for sure \\
\hline & $\mathrm{O}$ & $\mathrm{O}$ & $€ 16.00$ for sure \\
\hline & $\mathrm{O}$ & $\mathrm{O}$ & $€ 16.50$ for sure \\
\hline & $\mathrm{O}$ & $\mathrm{O}$ & $€ 17.00$ for sure \\
\hline & $\mathrm{O}$ & $\mathrm{O}$ & $€ 17.50$ for sure \\
\hline & $\mathrm{O}$ & $\mathrm{O}$ & $€ 18.00$ for sure \\
\hline & $\mathrm{O}$ & $\mathrm{O}$ & $€ 18.50$ for sure \\
\hline & $\mathrm{O}$ & $\mathrm{O}$ & $€ 19.00$ for sure \\
\hline & $\mathrm{O}$ & $\mathrm{O}$ & $€ 19.50$ for sure \\
\hline
\end{tabular}




\section{Decision 19}

\begin{tabular}{|c|c|c|c|}
\hline \multicolumn{2}{|c|}{ Lottery } & \multicolumn{2}{|c|}{ Sure } \\
\hline \multirow{13}{*}{ 101010 } & $\mathrm{O}$ & $\mathrm{O}$ & $€ 0.50$ for sure \\
\hline & $\mathrm{O}$ & $\mathrm{O}$ & $€ 1.00$ for sure \\
\hline & $\mathrm{O}$ & $\mathrm{O}$ & $€ 1.50$ for sure \\
\hline & $\mathrm{O}$ & $\mathrm{O}$ & $€ 2.00$ for sure \\
\hline & $\mathrm{O}$ & $\mathrm{O}$ & $€ 2.50$ for sure \\
\hline & $\mathrm{O}$ & $\mathrm{O}$ & $€ 3.00$ for sure \\
\hline & $\mathrm{O}$ & $\mathrm{O}$ & $€ 3.50$ for sure \\
\hline & $\mathrm{O}$ & $\mathrm{O}$ & $€ 4.00$ for sure \\
\hline & $\mathrm{O}$ & $\mathrm{O}$ & $€ 4.50$ for sure \\
\hline & $\mathrm{O}$ & $\mathrm{O}$ & $€ 5.00$ for sure \\
\hline & $\mathrm{O}$ & $\mathrm{O}$ & $€ 5.50$ for sure \\
\hline & $\mathrm{O}$ & $\mathrm{O}$ & $€ 6.00$ for sure \\
\hline & $\mathrm{O}$ & $\mathrm{O}$ & $€ 6.50$ for sure \\
\hline Win $€ 20$ if one of the following balls is extracted: & $\mathrm{O}$ & $\mathrm{O}$ & $€ 7.00$ for sure \\
\hline & $\mathrm{O}$ & $\mathrm{O}$ & $€ 7.50$ for sure \\
\hline & $\mathrm{O}$ & $\mathrm{O}$ & $€ 8.00$ for sure \\
\hline Win $€ \mathbf{0}$ if one of the following balls is extracted: & $\mathrm{O}$ & $\mathrm{O}$ & $€ 8.50$ for sure \\
\hline & $\mathrm{O}$ & $\mathrm{O}$ & $€ 9.00$ for sure \\
\hline & $\mathrm{O}$ & $\mathrm{O}$ & $€ 9.50$ for sure \\
\hline & $\mathrm{O}$ & $\mathrm{O}$ & $€ 10.00$ for sure \\
\hline & $\mathrm{O}$ & $\mathrm{O}$ & $€ 10.50$ for sure \\
\hline & $\mathrm{O}$ & $\mathrm{O}$ & $€ 11.00$ for sure \\
\hline & $\mathrm{O}$ & $\mathrm{O}$ & $€ 11.50$ for sure \\
\hline & $\mathrm{O}$ & $\mathrm{O}$ & $€ 12.00$ for sure \\
\hline & $\mathrm{O}$ & $\mathrm{O}$ & $€ 12.50$ for sure \\
\hline & $\mathrm{O}$ & $\mathrm{O}$ & $€ 13.00$ for sure \\
\hline & $\mathrm{O}$ & $\mathrm{O}$ & $€ 13.50$ for sure \\
\hline & $\mathrm{O}$ & $\mathrm{O}$ & $€ 14.00$ for sure \\
\hline & $\mathrm{O}$ & $\mathrm{O}$ & $€ 14.50$ for sure \\
\hline & $\mathrm{O}$ & $\mathrm{O}$ & $€ 15.00$ for sure \\
\hline & $\mathrm{O}$ & $\mathrm{O}$ & $€ 15.50$ for sure \\
\hline & $\mathrm{O}$ & $\mathrm{O}$ & $€ 16.00$ for sure \\
\hline & $\mathrm{O}$ & $\mathrm{O}$ & $€ 16.50$ for sure \\
\hline & $\mathrm{O}$ & $\mathrm{O}$ & $€ 17.00$ for sure \\
\hline & $\mathrm{O}$ & $\mathrm{O}$ & $€ 17.50$ for sure \\
\hline & $\mathrm{O}$ & $\mathrm{O}$ & $€ 18.00$ for sure \\
\hline & $\mathrm{O}$ & $\mathrm{O}$ & $€ 18.50$ for sure \\
\hline & $\mathrm{O}$ & $\mathrm{O}$ & $€ 19.00$ for sure \\
\hline & $\mathrm{O}$ & $\mathrm{O}$ & $€ 19.50$ for sure \\
\hline
\end{tabular}




\section{Decision 20}

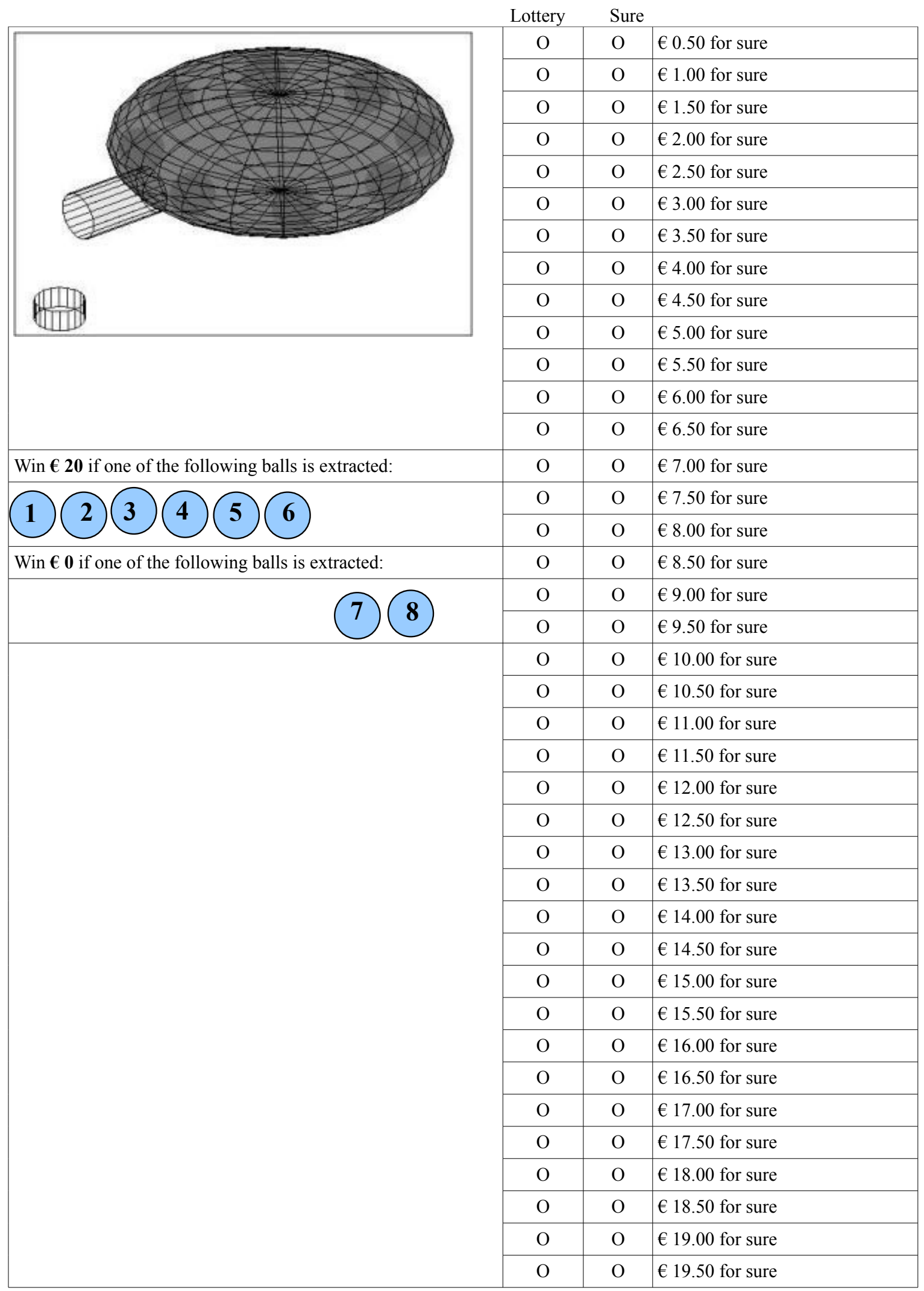




\section{Decision 21}

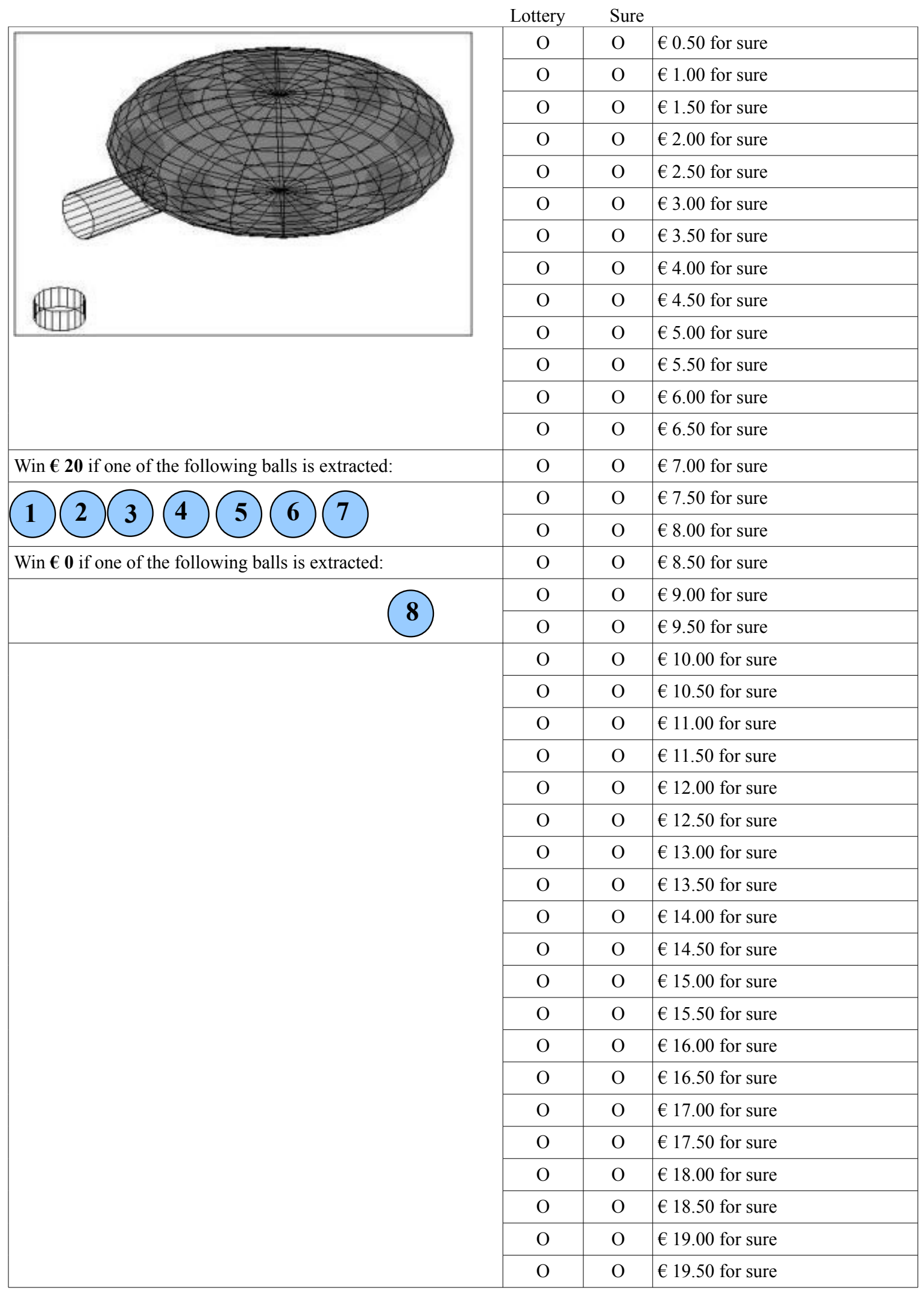


Decision 22

\begin{tabular}{|c|c|c|c|}
\hline \multicolumn{2}{|c|}{ Lottery } & \multicolumn{2}{|c|}{ Sure } \\
\hline \multirow{13}{*}{ :1ID } & $\mathrm{O}$ & $\mathrm{O}$ & $€ 5.50$ for sure \\
\hline & $\mathrm{O}$ & $\mathrm{O}$ & $€ 6.00$ for sure \\
\hline & $\mathrm{O}$ & $\mathrm{O}$ & $€ 6.50$ for sure \\
\hline & $\mathrm{O}$ & $\mathrm{O}$ & $€ 7.00$ for sure \\
\hline & $\mathrm{O}$ & $\mathrm{O}$ & $€ 7.50$ for sure \\
\hline & $\mathrm{O}$ & $\mathrm{O}$ & $€ 8.00$ for sure \\
\hline & $\mathrm{O}$ & $\mathrm{O}$ & $€ 8.50$ for sure \\
\hline & $\mathrm{O}$ & $\mathrm{O}$ & $€ 9.00$ for sure \\
\hline & $\mathrm{O}$ & $\mathrm{O}$ & $€ 9.50$ for sure \\
\hline & $\mathrm{O}$ & $\mathrm{O}$ & $€ 10.00$ for sure \\
\hline & $\mathrm{O}$ & $\mathrm{O}$ & $€ 10.50$ for sure \\
\hline & $\mathrm{O}$ & $\mathrm{O}$ & $€ 11.00$ for sure \\
\hline & $\mathrm{O}$ & $\mathrm{O}$ & $€ 11.50$ for sure \\
\hline \multirow[t]{3}{*}{ Win $€ 20$ if one of the following balls is extracted: } & $\mathrm{O}$ & $\mathrm{O}$ & $€ 12.00$ for sure \\
\hline & $\mathrm{O}$ & $\mathrm{O}$ & $€ 12.50$ for sure \\
\hline & $\mathrm{O}$ & $\mathrm{O}$ & $€ 13.00$ for sure \\
\hline \multirow[t]{14}{*}{ Win $€ \mathbf{5}$ if one of the following balls is extracted: } & $\mathrm{O}$ & $\mathrm{O}$ & $€ 13.50$ for sure \\
\hline & $\mathrm{O}$ & $\mathrm{O}$ & $€ 14.00$ for sure \\
\hline & $\mathrm{O}$ & $\mathrm{O}$ & $€ 14.50$ for sure \\
\hline & $\mathrm{O}$ & $\mathrm{O}$ & $€ 15.00$ for sure \\
\hline & $\mathrm{O}$ & $\mathrm{O}$ & $€ 15.50$ for sure \\
\hline & $\mathrm{O}$ & $\mathrm{O}$ & $€ 16.00$ for sure \\
\hline & $\mathrm{O}$ & $\mathrm{O}$ & $€ 16.50$ for sure \\
\hline & $\mathrm{O}$ & $\mathrm{O}$ & $€ 17.00$ for sure \\
\hline & $\mathrm{O}$ & $\mathrm{O}$ & $€ 17.50$ for sure \\
\hline & $\mathrm{O}$ & $\mathrm{O}$ & $€ 18.00$ for sure \\
\hline & $\mathrm{O}$ & $\mathrm{O}$ & $€ 18.50$ for sure \\
\hline & $\mathrm{O}$ & $\mathrm{O}$ & $€ 19.00$ for sure \\
\hline & $\mathrm{O}$ & $\mathrm{O}$ & $€ 19.50$ for sure \\
\hline & $\mathrm{O}$ & $\mathrm{O}$ & \\
\hline
\end{tabular}




\section{PART II}

If part II should be chosen for real play, you are endowed with $€ 20$. These $€ 20$ are yours, but it is possible that you will lose part or all of the money in the experiment (but no more than that).

In part II you are again asked to repeatedly choose between the two types of lotteries you have already encountered in part I of the experiment and a series of sure amounts. However, the main difference now is that the amounts involved are negative instead of positive. Figure 4 shows an example of such a choice.

Fig. 4: example of a typical decision task from part II

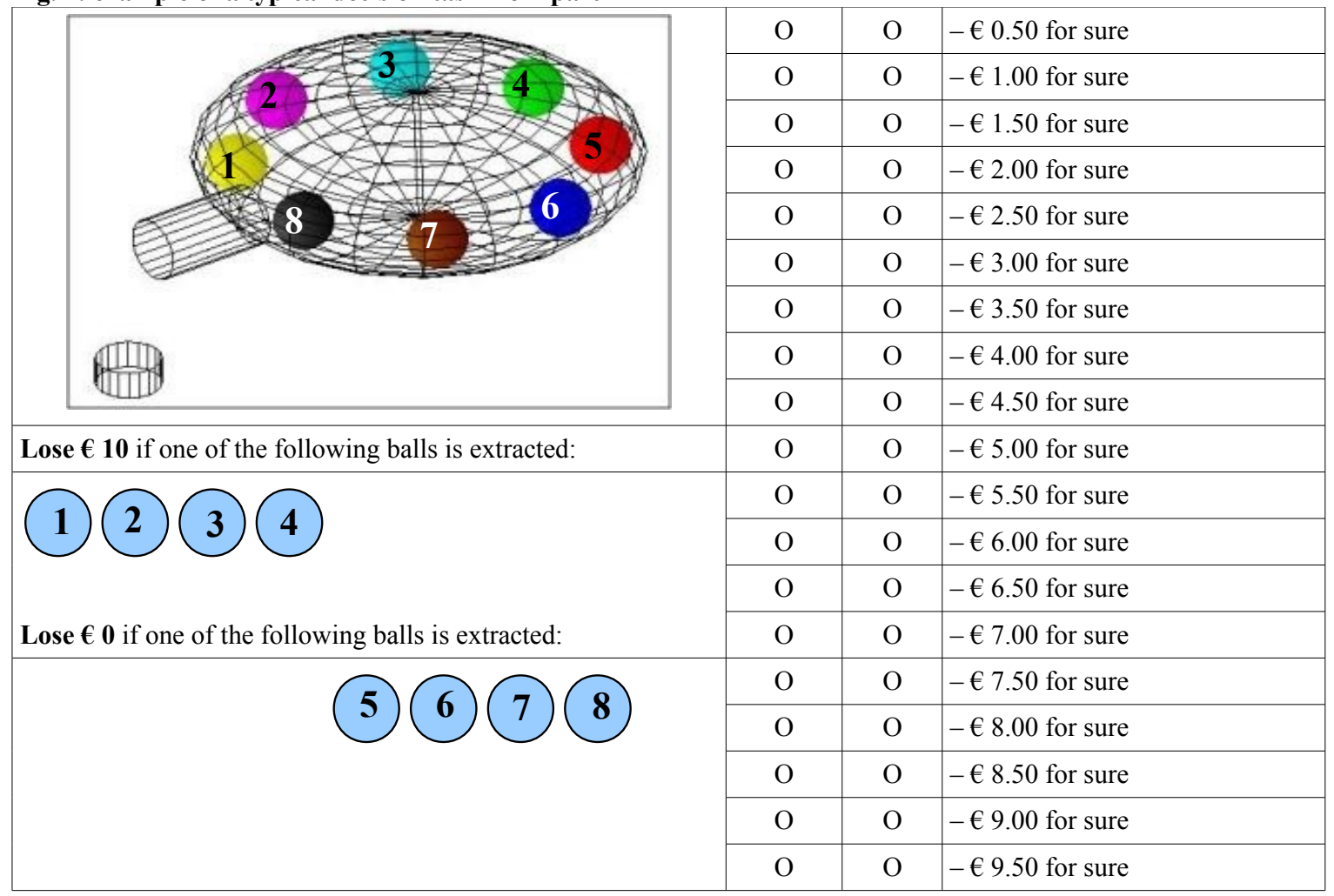

In the example displayed, you face the following lottery: if a ball with the number $1,2,3$, or 4 is extracted, you lose $\mathbf{€ 1 0}$. If a ball with the number $5,6,7$, or 8 is extracted, you lose nothing. Please choose again for each row whether you would rather give up (i.e., pay) the sure amount indicated to the right or play the lottery.

Notice that, most likely, you will now begin to the right by choosing to give up the sure amounts as long as this implies giving up small amounts, and then switch to the lottery at a certain point. If you do not want to give up sure amounts at all, then in the first row you can choose the lottery and then continue with the lottery for all choices (if you are not willing to pay $€ 0.50$ to avoid playing the lottery, then you should not be willing to pay $€ 1.00$ to avoid it). Once again, when exactly you switch from the sure loss to the lottery depends entirely on your preferences - there are no right or wrong answers. However, you should NOT switch back and forth several times between lottery and sure amount! You will be excluded from the experiment if you do so or if it is not possible to clearly recognize your preference (for example because you have not ticked any box for a given row or ticked both boxes for a row).

In addition to the pure loss choices described above, you will also face some choices in which both 
negative and positive amounts are involved. Also, what changes is now not the sure amount to the right, which is always equal to zero, but rather the amount you can lose in the lottery. Figure 3 shows an example of this kind of choice problem.

Fig. 3: decision task where lottery amount changes

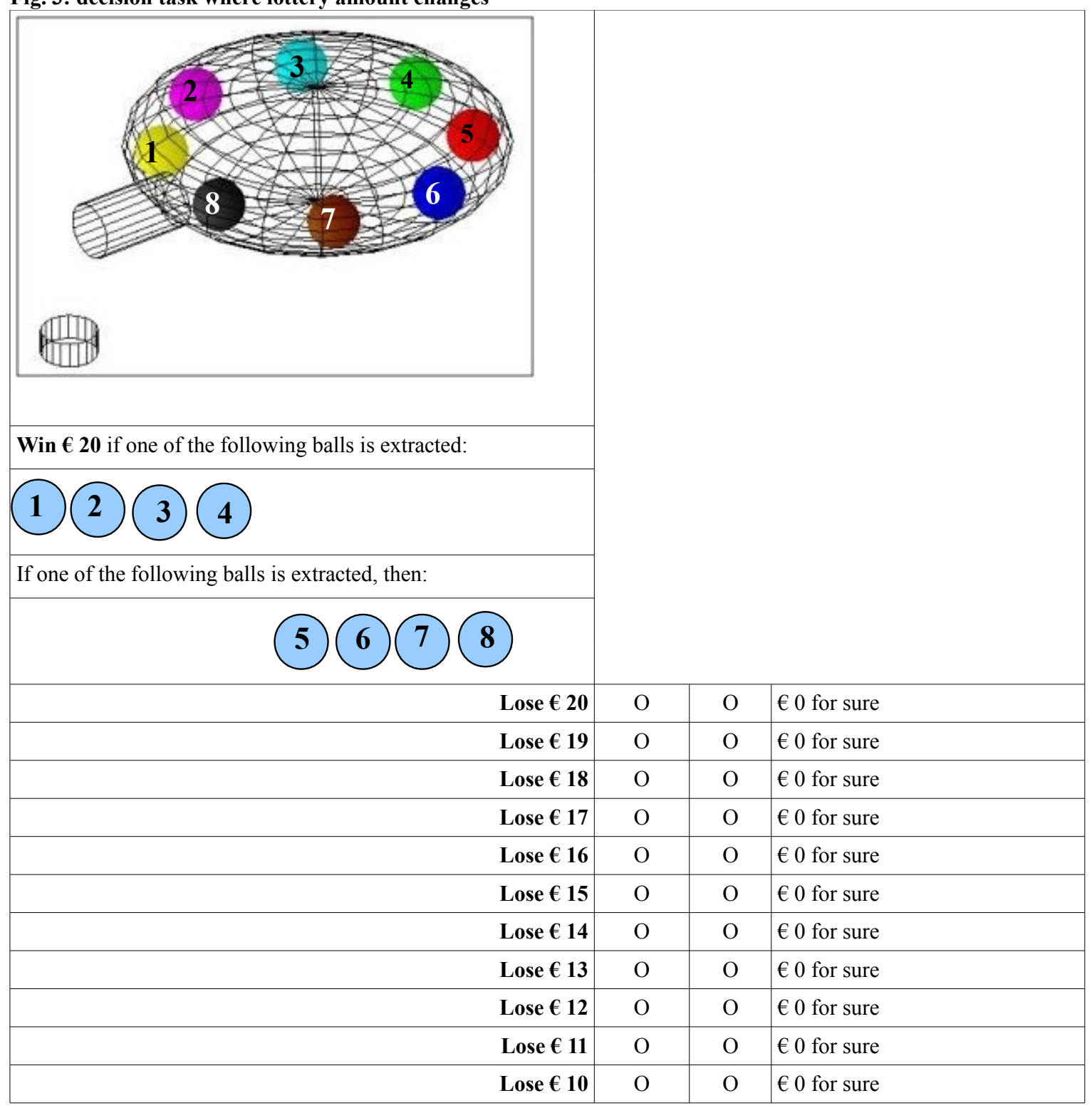

What is required of you in this task is exactly the same as for the other tasks. For each row, you should choose whether you prefer the sure amount to the right (which is now always zero), or the lottery to the left. Pay attention however: what changes is now the amount that can be lost in the lottery. Most likely, you would thus start from the right and choose zero for high losses, and then switch to the left as the losses in the lottery get smaller. You can however also start with the lottery and continue with it if that is your preference (if you prefer a lottery in which you can win $€ 20$ or lose $€ 20$ to zero, then you should also prefer the lottery when you can lose only $€ 19)$. When you switch from the zero sure amount to the lottery depends only on your preferences - there is no right or wrong answer. However, you should NOT switch back and forth several times between lottery and sure amount! You will be excluded from the experiment if you do so or if it is not possible to clearly recognize your preference (for example because you have not ticked any box for 
a given row or ticked both boxes for a row).

\section{Payoff determination}

In case part II should be chosen for real play, your payoff from part II will be determined in a way analogous to the payoff determination in the first part. First, one of the decision tasks will be chosen at random, and then one of the rows for which you had to indicate a choice. In each case, every choice task or row has an equal probability of being selected. According to your choice, you are will then have to pay the sure amount, or the lottery will be played out by drawing a ball from the indicated urn. 


\section{Decision II-1}

\begin{tabular}{|c|c|c|c|}
\hline \multirow{9}{*}{ AIIID } & \multirow{2}{*}{$\begin{array}{c}\text { Lottery } \\
\mathrm{O}\end{array}$} & Sure & \\
\hline & & $\mathrm{O}$ & $-€ 0.50$ for sure \\
\hline & $\mathrm{O}$ & $\mathrm{O}$ & $-€ 1.00$ for sure \\
\hline & $\mathrm{O}$ & $\mathrm{O}$ & $-€ 1.50$ for sure \\
\hline & $\mathrm{O}$ & $\mathrm{O}$ & $-€ 2.00$ for sure \\
\hline & $\mathrm{O}$ & $\mathrm{O}$ & $-€ 2.50$ for sure \\
\hline & $\mathrm{O}$ & $\mathrm{O}$ & $-€ 3.00$ for sure \\
\hline & $\mathrm{O}$ & $\mathrm{O}$ & $-€ 3.50$ for sure \\
\hline & $\mathrm{O}$ & $\mathrm{O}$ & $-€ 4.00$ for sure \\
\hline Lose $€ 5$ if one of the following balls is extracted: & $\mathrm{O}$ & $\mathrm{O}$ & $-€ 4.50$ for sure \\
\hline Lose $€ \mathbf{0}$ if one of the following balls is extracted: & & & \\
\hline
\end{tabular}




\section{Decision II-2}

\begin{tabular}{|c|c|c|c|}
\hline & Lottery & $\mathrm{Su}$ & \\
\hline & $\mathrm{O}$ & $\mathrm{O}$ & $-€ 0.50$ for sure \\
\hline & $\mathrm{O}$ & $\mathrm{O}$ & $-€ 1.00$ for sure \\
\hline & $\mathrm{O}$ & $\mathrm{O}$ & $-€ 1.50$ for sure \\
\hline & $\mathrm{O}$ & $\mathrm{O}$ & $-€ 2.00$ for sure \\
\hline & $\mathrm{O}$ & $\mathrm{O}$ & $-€ 2.50$ for sure \\
\hline & $\mathrm{O}$ & $\mathrm{O}$ & $-€ 3.00$ for sure \\
\hline & $\mathrm{O}$ & $\mathrm{O}$ & $-€ 3.50$ for sure \\
\hline & $\mathrm{O}$ & $\mathrm{O}$ & $-€ 4.00$ for sure \\
\hline AIIT & $\mathrm{O}$ & $\mathrm{O}$ & $-€ 4.50$ for sure \\
\hline & $\mathrm{O}$ & $\mathrm{O}$ & $-€ 5.00$ for sure \\
\hline & $\mathrm{O}$ & $\mathrm{O}$ & $-€ 5.50$ for sure \\
\hline & $\mathrm{O}$ & $\mathrm{O}$ & $-€ 6.00$ for sure \\
\hline & $\mathrm{O}$ & $\mathrm{O}$ & $-€ 6.50$ for sure \\
\hline Lose $€ 10$ if one of the following balls is extracted: & $\mathrm{O}$ & $\mathrm{O}$ & $-€ 7.00$ for sure \\
\hline & $\mathrm{O}$ & $\mathrm{O}$ & $-€ 7.50$ for sure \\
\hline & $\mathrm{O}$ & $\mathrm{O}$ & $-€ 8.00$ for sure \\
\hline Lose $\boldsymbol{E} \mathbf{0}$ if one of the following balls is extracted: & $\mathrm{O}$ & $\mathrm{O}$ & $-€ 8.50$ for sure \\
\hline & $\mathrm{O}$ & $\mathrm{O}$ & $-€ 9.00$ for sure \\
\hline & $\mathrm{O}$ & $\mathrm{O}$ & $-€ 9.50$ for sure \\
\hline
\end{tabular}




\section{Decision II-3}

Lottery Sure

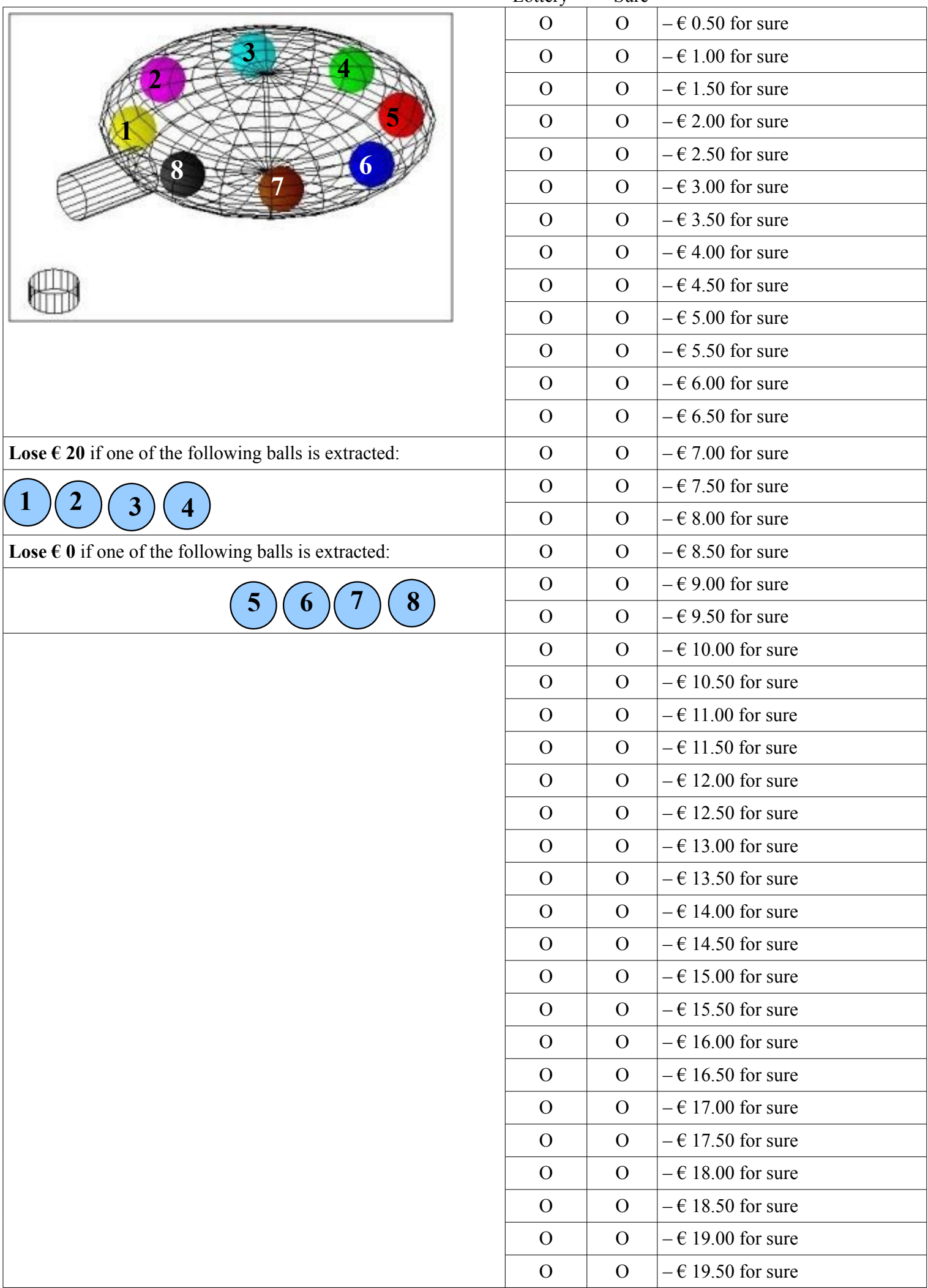




\section{Decision II-4}

\begin{tabular}{|c|c|c|c|}
\hline & Lottery & Sur & \\
\hline \multirow{13}{*}{ (III) } & $\mathrm{O}$ & $\mathrm{O}$ & $-€ 5.50$ for sure \\
\hline & $\mathrm{O}$ & $\mathrm{O}$ & $-€ 6.00$ for sure \\
\hline & $\mathrm{O}$ & $\mathrm{O}$ & $-€ 6.50$ for sure \\
\hline & $\mathrm{O}$ & $\mathrm{O}$ & $-€ 7.00$ for sure \\
\hline & $\mathrm{O}$ & $\mathrm{O}$ & $-€ 7.50$ for sure \\
\hline & $\mathrm{O}$ & $\mathrm{O}$ & $-€ 8.00$ for sure \\
\hline & $\mathrm{O}$ & $\mathrm{O}$ & $-€ 8.50$ for sure \\
\hline & $\mathrm{O}$ & $\mathrm{O}$ & $-€ 9.00$ for sure \\
\hline & $\mathrm{O}$ & $\mathrm{O}$ & $-€ 9.50$ for sure \\
\hline & $\mathrm{O}$ & $\mathrm{O}$ & $-€ 10.00$ for sure \\
\hline & $\mathrm{O}$ & $\mathrm{O}$ & $-€ 10.50$ for sure \\
\hline & $\mathrm{O}$ & $\mathrm{O}$ & $-€ 11.00$ for sure \\
\hline & $\mathrm{O}$ & $\mathrm{O}$ & $-€ 11.50$ for sure \\
\hline Lose $€ 20$ if one of the following balls is extracted: & $\mathrm{O}$ & $\mathrm{O}$ & $-€ 12.00$ for sure \\
\hline & $\mathrm{O}$ & $\mathrm{O}$ & $-€ 12.50$ for sure \\
\hline & $\mathrm{O}$ & $\mathrm{O}$ & $-€ 13.00$ for sure \\
\hline Lose $€ \mathbf{5}$ if one of the following balls is extracted: & $\mathrm{O}$ & $\mathrm{O}$ & $-€ 13.50$ for sure \\
\hline & $\mathrm{O}$ & $\mathrm{O}$ & $-€ 14.00$ for sure \\
\hline & $\mathrm{O}$ & $\mathrm{O}$ & $-€ 14.50$ for sure \\
\hline & $\mathrm{O}$ & $\mathrm{O}$ & $-€ 15.00$ for sure \\
\hline & $\mathrm{O}$ & $\mathrm{O}$ & $-€ 15.50$ for sure \\
\hline & $\mathrm{O}$ & $\mathrm{O}$ & $-€ 16.00$ for sure \\
\hline & $\mathrm{O}$ & $\mathrm{O}$ & $-€ 16.50$ for sure \\
\hline & $\mathrm{O}$ & $\mathrm{O}$ & $-€ 17.00$ for sure \\
\hline & $\mathrm{O}$ & $\mathrm{O}$ & $-€ 17.50$ for sure \\
\hline & $\mathrm{O}$ & $\mathrm{O}$ & $-€ 18.00$ for sure \\
\hline & $\mathrm{O}$ & $\mathrm{O}$ & $-€ 18.50$ for sure \\
\hline & $\mathrm{O}$ & $\mathrm{O}$ & $-€ 19.00$ for sure \\
\hline & $\mathrm{O}$ & $\mathrm{O}$ & $-€ 19.50$ for sure \\
\hline
\end{tabular}




\section{Decision II-5}

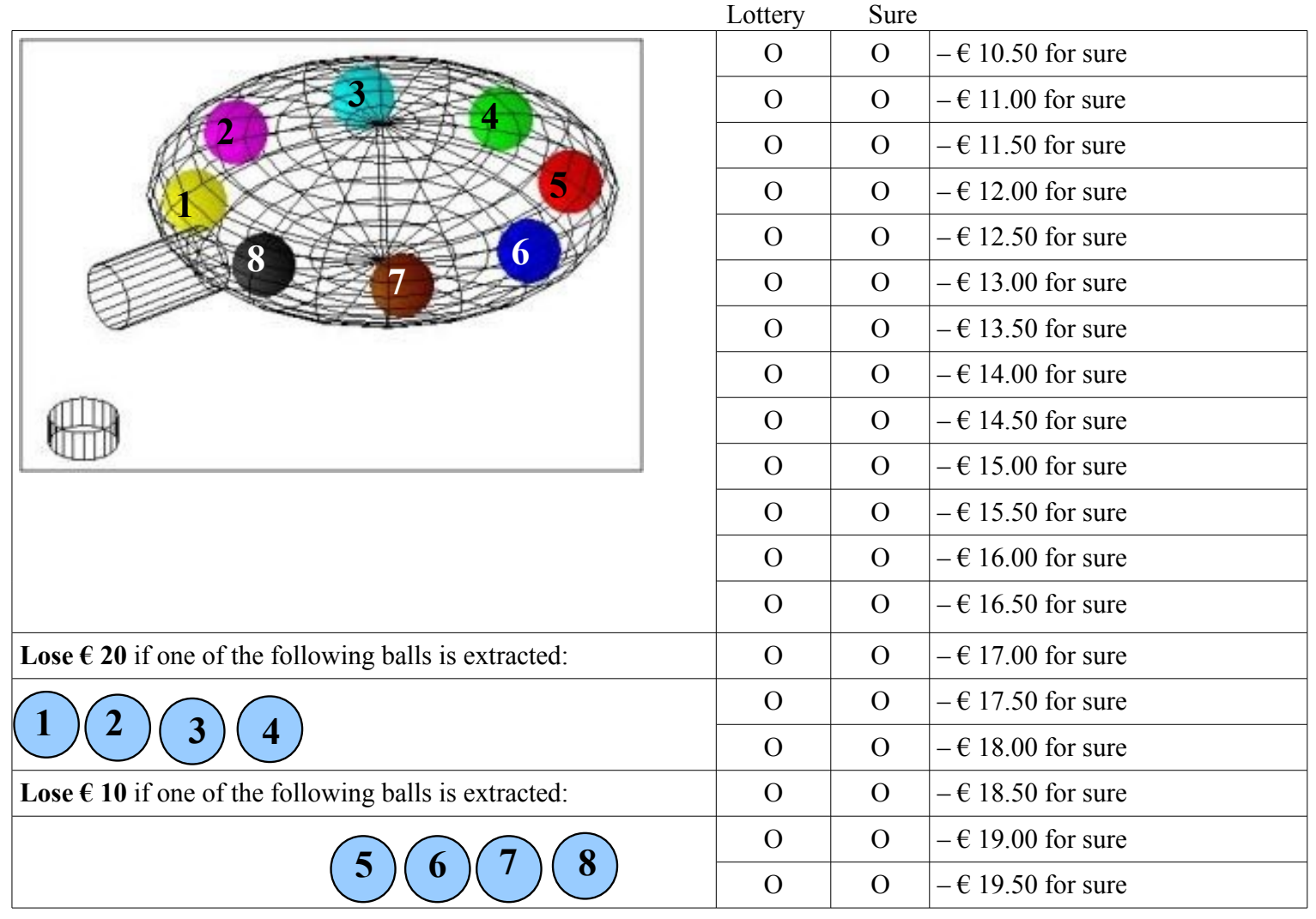




\section{Decision II-6}

\begin{tabular}{|c|c|c|c|}
\hline & Lottery & Sur & \\
\hline & $\mathrm{O}$ & $\mathrm{O}$ & $-€ 0.50$ for sure \\
\hline & $\mathrm{O}$ & $\mathrm{O}$ & $-€ 1.00$ for sure \\
\hline & $\mathrm{O}$ & $\mathrm{O}$ & $-€ 1.50$ for sure \\
\hline & $\mathrm{O}$ & $\mathrm{O}$ & $-€ 2.00$ for sure \\
\hline & $\mathrm{O}$ & $\mathrm{O}$ & $-€ 2.50$ for sure \\
\hline & $\mathrm{O}$ & $\mathrm{O}$ & $-€ 3.00$ for sure \\
\hline & $\mathrm{O}$ & $\mathrm{O}$ & $-€ 3.50$ for sure \\
\hline & $\mathrm{O}$ & $\mathrm{O}$ & $-€ 4.00$ for sure \\
\hline & $\mathrm{O}$ & $\mathrm{O}$ & $-€ 4.50$ for sure \\
\hline & $\mathrm{O}$ & $\mathrm{O}$ & $-€ 5.00$ for sure \\
\hline & $\mathrm{O}$ & $\mathrm{O}$ & $-€ 5.50$ for sure \\
\hline & $\mathrm{O}$ & $\mathrm{O}$ & $-€ 6.00$ for sure \\
\hline & $\mathrm{O}$ & $\mathrm{O}$ & $-€ 6.50$ for sure \\
\hline Lose $€ 20$ if one of the following balls is extracted: & $\mathrm{O}$ & $\mathrm{O}$ & $-€ 7.00$ for sure \\
\hline 1 & $\mathrm{O}$ & $\mathrm{O}$ & $-€ 7.50$ for sure \\
\hline & $\mathrm{O}$ & $\mathrm{O}$ & $-€ 8.00$ for sure \\
\hline Lose $€ \mathbf{0}$ if one of the following balls is extracted: & $\mathrm{O}$ & $\mathrm{O}$ & $-€ 8.50$ for sure \\
\hline & $\mathrm{O}$ & $\mathrm{O}$ & $-€ 9.00$ for sure \\
\hline & $\mathrm{O}$ & $\mathrm{O}$ & $-€ 9.50$ for sure \\
\hline & $\mathrm{O}$ & $\mathrm{O}$ & $-€ 10.00$ for sure \\
\hline & $\mathrm{O}$ & $\mathrm{O}$ & $-€ 10.50$ for sure \\
\hline & $\mathrm{O}$ & $\mathrm{O}$ & $-€ 11.00$ for sure \\
\hline & $\mathrm{O}$ & $\mathrm{O}$ & $-€ 11.50$ for sure \\
\hline & $\mathrm{O}$ & $\mathrm{O}$ & $-€ 12.00$ for sure \\
\hline & $\mathrm{O}$ & $\mathrm{O}$ & $-€ 12.50$ for sure \\
\hline & $\mathrm{O}$ & $\mathrm{O}$ & $-€ 13.00$ for sure \\
\hline & $\mathrm{O}$ & $\mathrm{O}$ & $-€ 13.50$ for sure \\
\hline & $\mathrm{O}$ & $\mathrm{O}$ & $-€ 14.00$ for sure \\
\hline & $\mathrm{O}$ & $\mathrm{O}$ & $-€ 14.50$ for sure \\
\hline & $\mathrm{O}$ & $\mathrm{O}$ & $-€ 15.00$ for sure \\
\hline & $\mathrm{O}$ & $\mathrm{O}$ & $-€ 15.50$ for sure \\
\hline & $\mathrm{O}$ & $\mathrm{O}$ & $-€ 16.00$ for sure \\
\hline & $\mathrm{O}$ & $\mathrm{O}$ & $-€ 16.50$ for sure \\
\hline & $\mathrm{O}$ & $\mathrm{O}$ & $-€ 17.00$ for sure \\
\hline & $\mathrm{O}$ & $\mathrm{O}$ & $-€ 17.50$ for sure \\
\hline & $\mathrm{O}$ & $\mathrm{O}$ & $-€ 18.00$ for sure \\
\hline & $\mathrm{O}$ & $\mathrm{O}$ & $-€ 18.50$ for sure \\
\hline & $\mathrm{O}$ & $\mathrm{O}$ & $-€ 19.00$ for sure \\
\hline & $\mathrm{O}$ & $\mathrm{O}$ & $-€ 19.50$ for sure \\
\hline
\end{tabular}




\section{Decision II-7}

\begin{tabular}{|c|c|c|c|}
\hline & Lottery & Sur & \\
\hline & $\mathrm{O}$ & $\mathrm{O}$ & $-€ 5.50$ for sure \\
\hline & $\mathrm{O}$ & $\mathrm{O}$ & $-€ 6.00$ for sure \\
\hline & $\mathrm{O}$ & $\mathrm{O}$ & $-€ 6.50$ for sure \\
\hline & $\mathrm{O}$ & $\mathrm{O}$ & $-€ 7.00$ for sure \\
\hline & $\mathrm{O}$ & $\mathrm{O}$ & $-€ 7.50$ for sure \\
\hline & $\mathrm{O}$ & $\mathrm{O}$ & $-€ 8.00$ for sure \\
\hline & $\mathrm{O}$ & $\mathrm{O}$ & $-€ 8.50$ for sure \\
\hline & $\mathrm{O}$ & $\mathrm{O}$ & $-€ 9.00$ for sure \\
\hline AIIT & $\mathrm{O}$ & $\mathrm{O}$ & $-€ 9.50$ for sure \\
\hline & $\mathrm{O}$ & $\mathrm{O}$ & $-€ 10.00$ for sure \\
\hline & $\mathrm{O}$ & $\mathrm{O}$ & $-€ 10.50$ for sure \\
\hline & $\mathrm{O}$ & $\mathrm{O}$ & $-€ 11.00$ for sure \\
\hline & $\mathrm{O}$ & $\mathrm{O}$ & $-€ 11.50$ for sure \\
\hline Lose $\boldsymbol{\epsilon} \mathbf{2 0}$ if one of the following balls is extracted: & $\mathrm{O}$ & $\mathrm{O}$ & $-€ 12.00$ for sure \\
\hline 1 & $\mathrm{O}$ & $\mathrm{O}$ & $-€ 12.50$ for sure \\
\hline & $\mathrm{O}$ & $\mathrm{O}$ & $-€ 13.00$ for sure \\
\hline Lose $€ \mathbf{5}$ if one of the following balls is extracted: & $\mathrm{O}$ & $\mathrm{O}$ & $-€ 13.50$ for sure \\
\hline & $\mathrm{O}$ & $\mathrm{O}$ & $-€ 14.00$ for sure \\
\hline & $\mathrm{O}$ & $\mathrm{O}$ & $-€ 14.50$ for sure \\
\hline & $\mathrm{O}$ & $\mathrm{O}$ & $-€ 15.00$ for sure \\
\hline & $\mathrm{O}$ & $\mathrm{O}$ & $-€ 15.50$ for sure \\
\hline & $\mathrm{O}$ & $\mathrm{O}$ & $-€ 16.00$ for sure \\
\hline & $\mathrm{O}$ & $\mathrm{O}$ & $-€ 16.50$ for sure \\
\hline & $\mathrm{O}$ & $\mathrm{O}$ & $-€ 17.00$ for sure \\
\hline & $\mathrm{O}$ & $\mathrm{O}$ & $-€ 17.50$ for sure \\
\hline & $\mathrm{O}$ & $\mathrm{O}$ & $-€ 18.00$ for sure \\
\hline & $\mathrm{O}$ & $\mathrm{O}$ & $-€ 18.50$ for sure \\
\hline & $\mathrm{O}$ & $\mathrm{O}$ & $-€ 19.00$ for sure \\
\hline & $\mathrm{O}$ & $\mathrm{O}$ & $-€ 19.50$ for sure \\
\hline
\end{tabular}




\section{Decision II-8}

\begin{tabular}{|c|c|c|c|}
\hline & Lottery & $\mathrm{Su}$ & \\
\hline & $\mathrm{O}$ & $\mathrm{O}$ & $-€ 0.50$ for sure \\
\hline & $\mathrm{O}$ & $\mathrm{O}$ & $-€ 1.00$ for sure \\
\hline & $\mathrm{O}$ & $\mathrm{O}$ & $-€ 1.50$ for sure \\
\hline & $\mathrm{O}$ & $\mathrm{O}$ & $-€ 2.00$ for sure \\
\hline & $\mathrm{O}$ & $\mathrm{O}$ & $-€ 2.50$ for sure \\
\hline & $\mathrm{O}$ & $\mathrm{O}$ & $-€ 3.00$ for sure \\
\hline & $\mathrm{O}$ & $\mathrm{O}$ & $-€ 3.50$ for sure \\
\hline & $\mathrm{O}$ & $\mathrm{O}$ & $-€ 4.00$ for sure \\
\hline AII & $\mathrm{O}$ & $\mathrm{O}$ & $-€ 4.50$ for sure \\
\hline & $\mathrm{O}$ & $\mathrm{O}$ & $-€ 5.00$ for sure \\
\hline & $\mathrm{O}$ & $\mathrm{O}$ & $-€ 5.50$ for sure \\
\hline & $\mathrm{O}$ & $\mathrm{O}$ & $-€ 6.00$ for sure \\
\hline & $\mathrm{O}$ & $\mathrm{O}$ & $-€ 6.50$ for sure \\
\hline Lose $€ 20$ if one of the following balls is extracted: & $\mathrm{O}$ & $\mathrm{O}$ & $-€ 7.00$ for sure \\
\hline 22 & $\mathrm{O}$ & $\mathrm{O}$ & $-€ 7.50$ for sure \\
\hline 12 & $\mathrm{O}$ & $\mathrm{O}$ & $-€ 8.00$ for sure \\
\hline Lose $\boldsymbol{€ 0}$ if one of the following balls is extracted: & $\mathrm{O}$ & $\mathrm{O}$ & $-€ 8.50$ for sure \\
\hline & $\mathrm{O}$ & $\mathrm{O}$ & $-€ 9.00$ for sure \\
\hline & $\mathrm{O}$ & $\mathrm{O}$ & $-€ 9.50$ for sure \\
\hline & $\mathrm{O}$ & $\mathrm{O}$ & $-€ 10.00$ for sure \\
\hline & $\mathrm{O}$ & $\mathrm{O}$ & $-€ 10.50$ for sure \\
\hline & $\mathrm{O}$ & $\mathrm{O}$ & $-€ 11.00$ for sure \\
\hline & $\mathrm{O}$ & $\mathrm{O}$ & $-€ 11.50$ for sure \\
\hline & $\mathrm{O}$ & $\mathrm{O}$ & $-€ 12.00$ for sure \\
\hline & $\mathrm{O}$ & $\mathrm{O}$ & $-€ 12.50$ for sure \\
\hline & $\mathrm{O}$ & $\mathrm{O}$ & $-€ 13.00$ for sure \\
\hline & $\mathrm{O}$ & $\mathrm{O}$ & $-€ 13.50$ for sure \\
\hline & $\mathrm{O}$ & $\mathrm{O}$ & $-€ 14.00$ for sure \\
\hline & $\mathrm{O}$ & $\mathrm{O}$ & $-€ 14.50$ for sure \\
\hline & $\mathrm{O}$ & $\mathrm{O}$ & $-€ 15.00$ for sure \\
\hline & $\mathrm{O}$ & $\mathrm{O}$ & $-€ 15.50$ for sure \\
\hline & $\mathrm{O}$ & $\mathrm{O}$ & $-€ 16.00$ for sure \\
\hline & $\mathrm{O}$ & $\mathrm{O}$ & $-€ 16.50$ for sure \\
\hline & $\mathrm{O}$ & $\mathrm{O}$ & $-€ 17.00$ for sure \\
\hline & $\mathrm{O}$ & $\mathrm{O}$ & $-€ 17.50$ for sure \\
\hline & $\mathrm{O}$ & $\mathrm{O}$ & $-€ 18.00$ for sure \\
\hline & $\mathrm{O}$ & $\mathrm{O}$ & $-€ 18.50$ for sure \\
\hline & $\mathrm{O}$ & $\mathrm{O}$ & $-€ 19.00$ for sure \\
\hline & $\mathrm{O}$ & $\mathrm{O}$ & $-€ 19.50$ for sure \\
\hline
\end{tabular}




\section{Decision II-9}

\begin{tabular}{|c|c|c|c|}
\hline & Lottery & $\mathrm{Su}$ & \\
\hline & $\mathrm{O}$ & $\mathrm{O}$ & $-€ 0.50$ for sure \\
\hline & $\mathrm{O}$ & $\mathrm{O}$ & $-€ 1.00$ for sure \\
\hline & $\mathrm{O}$ & $\mathrm{O}$ & $-€ 1.50$ for sure \\
\hline & $\mathrm{O}$ & $\mathrm{O}$ & $-€ 2.00$ for sure \\
\hline & $\mathrm{O}$ & $\mathrm{O}$ & $-€ 2.50$ for sure \\
\hline & $\mathrm{O}$ & $\mathrm{O}$ & $-€ 3.00$ for sure \\
\hline & $\mathrm{O}$ & $\mathrm{O}$ & $-€ 3.50$ for sure \\
\hline & $\mathrm{O}$ & $\mathrm{O}$ & $-€ 4.00$ for sure \\
\hline & $\mathrm{O}$ & $\mathrm{O}$ & $-€ 4.50$ for sure \\
\hline & $\mathrm{O}$ & $\mathrm{O}$ & $-€ 5.00$ for sure \\
\hline & $\mathrm{O}$ & $\mathrm{O}$ & $-€ 5.50$ for sure \\
\hline & $\mathrm{O}$ & $\mathrm{O}$ & $-€ 6.00$ for sure \\
\hline & $\mathrm{O}$ & $\mathrm{O}$ & $-€ 6.50$ for sure \\
\hline Lose $€ 20$ if one of the following balls is extracted: & $\mathrm{O}$ & $\mathrm{O}$ & $-€ 7.00$ for sure \\
\hline & $\mathrm{O}$ & $\mathrm{O}$ & $-€ 7.50$ for sure \\
\hline & $\mathrm{O}$ & $\mathrm{O}$ & $-€ 8.00$ for sure \\
\hline Lose $€ \mathbf{0}$ if one of the following balls is extracted: & $\mathrm{O}$ & $\mathrm{O}$ & $-€ 8.50$ for sure \\
\hline & $\mathrm{O}$ & $\mathrm{O}$ & $-€ 9.00$ for sure \\
\hline & $\mathrm{O}$ & $\mathrm{O}$ & $-€ 9.50$ for sure \\
\hline & $\mathrm{O}$ & $\mathrm{O}$ & $-€ 10.00$ for sure \\
\hline & $\mathrm{O}$ & $\mathrm{O}$ & $-€ 10.50$ for sure \\
\hline & $\mathrm{O}$ & $\mathrm{O}$ & $-€ 11.00$ for sure \\
\hline & $\mathrm{O}$ & $\mathrm{O}$ & $-€ 11.50$ for sure \\
\hline & $\mathrm{O}$ & $\mathrm{O}$ & $-€ 12.00$ for sure \\
\hline & $\mathrm{O}$ & $\mathrm{O}$ & $-€ 12.50$ for sure \\
\hline & $\mathrm{O}$ & $\mathrm{O}$ & $-€ 13.00$ for sure \\
\hline & $\mathrm{O}$ & $\mathrm{O}$ & $-€ 13.50$ for sure \\
\hline & $\mathrm{O}$ & $\mathrm{O}$ & $-€ 14.00$ for sure \\
\hline & $\mathrm{O}$ & $\mathrm{O}$ & $-€ 14.50$ for sure \\
\hline & $\mathrm{O}$ & $\mathrm{O}$ & $-€ 15.00$ for sure \\
\hline & $\mathrm{O}$ & $\mathrm{O}$ & $-€ 15.50$ for sure \\
\hline & $\mathrm{O}$ & $\mathrm{O}$ & $-€ 16.00$ for sure \\
\hline & $\mathrm{O}$ & $\mathrm{O}$ & $-€ 16.50$ for sure \\
\hline & $\mathrm{O}$ & $\mathrm{O}$ & $-€ 17.00$ for sure \\
\hline & $\mathrm{O}$ & $\mathrm{O}$ & $-€ 17.50$ for sure \\
\hline & $\mathrm{O}$ & $\mathrm{O}$ & $-€ 18.00$ for sure \\
\hline & $\mathrm{O}$ & $\mathrm{O}$ & $-€ 18.50$ for sure \\
\hline & $\mathrm{O}$ & $\mathrm{O}$ & $-€ 19.00$ for sure \\
\hline & $\mathrm{O}$ & $\mathrm{O}$ & $-€ 19.50$ for sure \\
\hline
\end{tabular}




\section{Decision II-10}

\begin{tabular}{|c|c|c|c|}
\hline & Lottery & $\mathrm{Su}$ & \\
\hline & $\mathrm{O}$ & $\mathrm{O}$ & $-€ 0.50$ for sure \\
\hline & $\mathrm{O}$ & $\mathrm{O}$ & $-€ 1.00$ for sure \\
\hline & $\mathrm{O}$ & $\mathrm{O}$ & $-€ 1.50$ for sure \\
\hline & $\mathrm{O}$ & $\mathrm{O}$ & $-€ 2.00$ for sure \\
\hline & $\mathrm{O}$ & $\mathrm{O}$ & $-€ 2.50$ for sure \\
\hline & $\mathrm{O}$ & $\mathrm{O}$ & $-€ 3.00$ for sure \\
\hline & $\mathrm{O}$ & $\mathrm{O}$ & $-€ 3.50$ for sure \\
\hline & $\mathrm{O}$ & $\mathrm{O}$ & $-€ 4.00$ for sure \\
\hline AII & $\mathrm{O}$ & $\mathrm{O}$ & $-€ 4.50$ for sure \\
\hline & $\mathrm{O}$ & $\mathrm{O}$ & $-€ 5.00$ for sure \\
\hline & $\mathrm{O}$ & $\mathrm{O}$ & $-€ 5.50$ for sure \\
\hline & $\mathrm{O}$ & $\mathrm{O}$ & $-€ 6.00$ for sure \\
\hline & $\mathrm{O}$ & $\mathrm{O}$ & $-€ 6.50$ for sure \\
\hline Lose $€ \mathbf{2 0}$ if one of the following balls is extracted: & $\mathrm{O}$ & $\mathrm{O}$ & $-€ 7.00$ for sure \\
\hline & $\mathrm{O}$ & $\mathrm{O}$ & $-€ 7.50$ for sure \\
\hline & $\mathrm{O}$ & $\mathrm{O}$ & $-€ 8.00$ for sure \\
\hline Lose $\boldsymbol{€ 0}$ if one of the following balls is extracted: & $\mathrm{O}$ & $\mathrm{O}$ & $-€ 8.50$ for sure \\
\hline & $\mathrm{O}$ & $\mathrm{O}$ & $-€ 9.00$ for sure \\
\hline & $\mathrm{O}$ & $\mathrm{O}$ & $-€ 9.50$ for sure \\
\hline & $\mathrm{O}$ & $\mathrm{O}$ & $-€ 10.00$ for sure \\
\hline & $\mathrm{O}$ & $\mathrm{O}$ & $-€ 10.50$ for sure \\
\hline & $\mathrm{O}$ & $\mathrm{O}$ & $-€ 11.00$ for sure \\
\hline & $\mathrm{O}$ & $\mathrm{O}$ & $-€ 11.50$ for sure \\
\hline & $\mathrm{O}$ & $\mathrm{O}$ & $-€ 12.00$ for sure \\
\hline & $\mathrm{O}$ & $\mathrm{O}$ & $-€ 12.50$ for sure \\
\hline & $\mathrm{O}$ & $\mathrm{O}$ & $-€ 13.00$ for sure \\
\hline & $\mathrm{O}$ & $\mathrm{O}$ & $-€ 13.50$ for sure \\
\hline & $\mathrm{O}$ & $\mathrm{O}$ & $-€ 14.00$ for sure \\
\hline & $\mathrm{O}$ & $\mathrm{O}$ & $-€ 14.50$ for sure \\
\hline & $\mathrm{O}$ & $\mathrm{O}$ & $-€ 15.00$ for sure \\
\hline & $\mathrm{O}$ & $\mathrm{O}$ & $-€ 15.50$ for sure \\
\hline & $\mathrm{O}$ & $\mathrm{O}$ & $-€ 16.00$ for sure \\
\hline & $\mathrm{O}$ & $\mathrm{O}$ & $-€ 16.50$ for sure \\
\hline & $\mathrm{O}$ & $\mathrm{O}$ & $-€ 17.00$ for sure \\
\hline & $\mathrm{O}$ & $\mathrm{O}$ & $-€ 17.50$ for sure \\
\hline & $\mathrm{O}$ & $\mathrm{O}$ & $-€ 18.00$ for sure \\
\hline & $\mathrm{O}$ & $\mathrm{O}$ & $-€ 18.50$ for sure \\
\hline & $\mathrm{O}$ & $\mathrm{O}$ & $-€ 19.00$ for sure \\
\hline & $\mathrm{O}$ & $\mathrm{O}$ & $-€ 19.50$ for sure \\
\hline
\end{tabular}




\section{Decision II-11}

\begin{tabular}{|c|c|c|c|}
\hline & Lottery & $\mathrm{Su}$ & \\
\hline & $\mathrm{O}$ & $\mathrm{O}$ & $-€ 0.50$ for sure \\
\hline & $\mathrm{O}$ & $\mathrm{O}$ & $-€ 1.00$ for sure \\
\hline & $\mathrm{O}$ & $\mathrm{O}$ & $-€ 1.50$ for sure \\
\hline & $\mathrm{O}$ & $\mathrm{O}$ & $-€ 2.00$ for sure \\
\hline & $\mathrm{O}$ & $\mathrm{O}$ & $-€ 2.50$ for sure \\
\hline & $\mathrm{O}$ & $\mathrm{O}$ & $-€ 3.00$ for sure \\
\hline & $\mathrm{O}$ & $\mathrm{O}$ & $-€ 3.50$ for sure \\
\hline & $\mathrm{O}$ & $\mathrm{O}$ & $-€ 4.00$ for sure \\
\hline AII & $\mathrm{O}$ & $\mathrm{O}$ & $-€ 4.50$ for sure \\
\hline & $\mathrm{O}$ & $\mathrm{O}$ & $-€ 5.00$ for sure \\
\hline & $\mathrm{O}$ & $\mathrm{O}$ & $-€ 5.50$ for sure \\
\hline & $\mathrm{O}$ & $\mathrm{O}$ & $-€ 6.00$ for sure \\
\hline & $\mathrm{O}$ & $\mathrm{O}$ & $-€ 6.50$ for sure \\
\hline Lose $€ \mathbf{2 0}$ if one of the following balls is extracted: & $\mathrm{O}$ & $\mathrm{O}$ & $-€ 7.00$ for sure \\
\hline & $\mathrm{O}$ & $\mathrm{O}$ & $-€ 7.50$ for sure \\
\hline & $\mathrm{O}$ & $\mathrm{O}$ & $-€ 8.00$ for sure \\
\hline Lose $\boldsymbol{€ 0}$ if one of the following balls is extracted: & $\mathrm{O}$ & $\mathrm{O}$ & $-€ 8.50$ for sure \\
\hline & $\mathrm{O}$ & $\mathrm{O}$ & $-€ 9.00$ for sure \\
\hline & $\mathrm{O}$ & $\mathrm{O}$ & $-€ 9.50$ for sure \\
\hline & $\mathrm{O}$ & $\mathrm{O}$ & $-€ 10.00$ for sure \\
\hline & $\mathrm{O}$ & $\mathrm{O}$ & $-€ 10.50$ for sure \\
\hline & $\mathrm{O}$ & $\mathrm{O}$ & $-€ 11.00$ for sure \\
\hline & $\mathrm{O}$ & $\mathrm{O}$ & $-€ 11.50$ for sure \\
\hline & $\mathrm{O}$ & $\mathrm{O}$ & $-€ 12.00$ for sure \\
\hline & $\mathrm{O}$ & $\mathrm{O}$ & $-€ 12.50$ for sure \\
\hline & $\mathrm{O}$ & $\mathrm{O}$ & $-€ 13.00$ for sure \\
\hline & $\mathrm{O}$ & $\mathrm{O}$ & $-€ 13.50$ for sure \\
\hline & $\mathrm{O}$ & $\mathrm{O}$ & $-€ 14.00$ for sure \\
\hline & $\mathrm{O}$ & $\mathrm{O}$ & $-€ 14.50$ for sure \\
\hline & $\mathrm{O}$ & $\mathrm{O}$ & $-€ 15.00$ for sure \\
\hline & $\mathrm{O}$ & $\mathrm{O}$ & $-€ 15.50$ for sure \\
\hline & $\mathrm{O}$ & $\mathrm{O}$ & $-€ 16.00$ for sure \\
\hline & $\mathrm{O}$ & $\mathrm{O}$ & $-€ 16.50$ for sure \\
\hline & $\mathrm{O}$ & $\mathrm{O}$ & $-€ 17.00$ for sure \\
\hline & $\mathrm{O}$ & $\mathrm{O}$ & $-€ 17.50$ for sure \\
\hline & $\mathrm{O}$ & $\mathrm{O}$ & $-€ 18.00$ for sure \\
\hline & $\mathrm{O}$ & $\mathrm{O}$ & $-€ 18.50$ for sure \\
\hline & $\mathrm{O}$ & $\mathrm{O}$ & $-€ 19.00$ for sure \\
\hline & $\mathrm{O}$ & $\mathrm{O}$ & $-€ 19.50$ for sure \\
\hline
\end{tabular}




\section{Decision II-12}

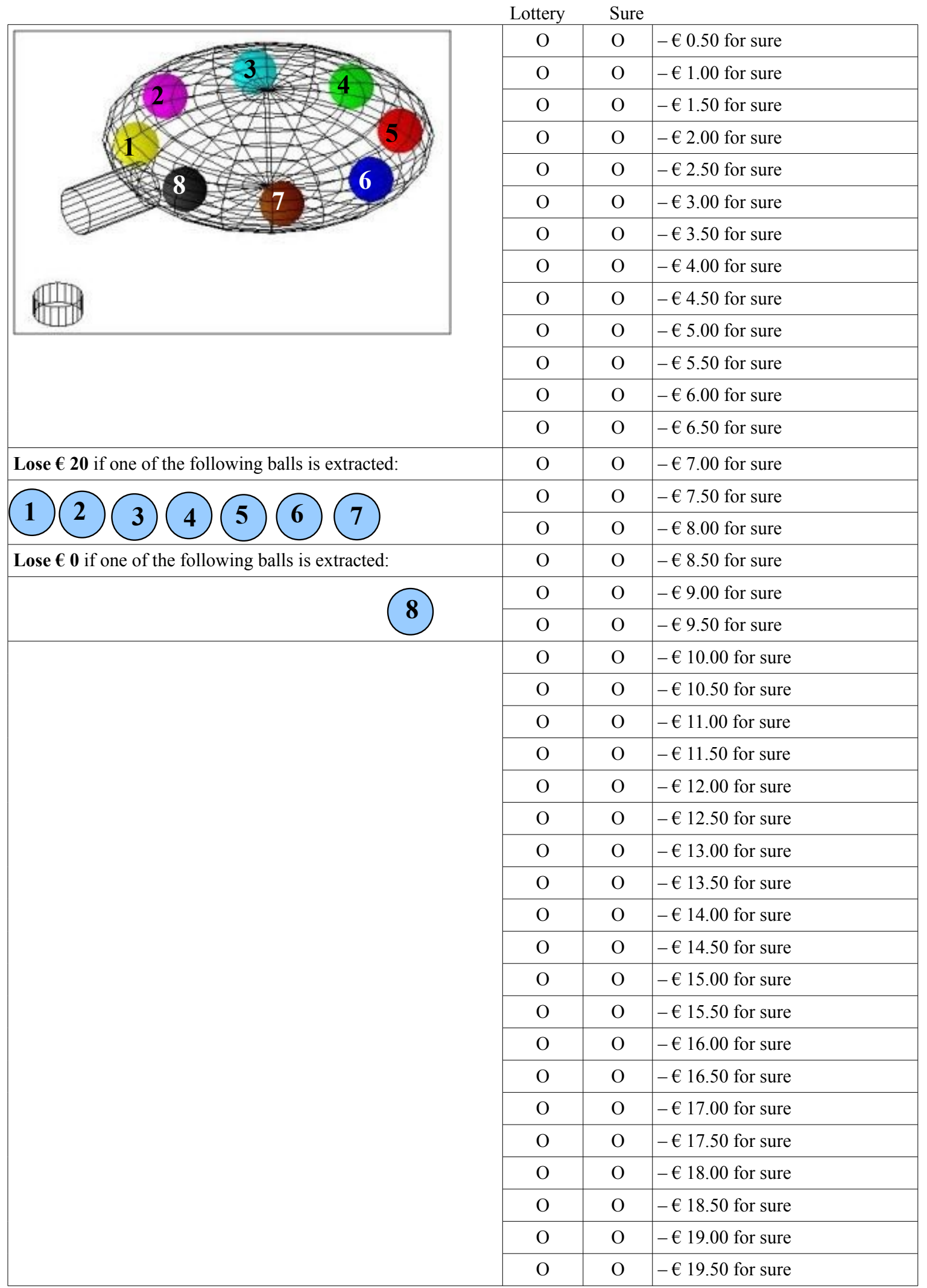




\section{Decision II-13}

\begin{tabular}{|c|c|c|c|}
\hline & Lottery & $\mathrm{Su}$ & \\
\hline & $\mathrm{O}$ & $\mathrm{O}$ & $-€ 5.50$ for sure \\
\hline & $\mathrm{O}$ & $\mathrm{O}$ & $-€ 6.00$ for sure \\
\hline & $\mathrm{O}$ & $\mathrm{O}$ & $-€ 6.50$ for sure \\
\hline & $\mathrm{O}$ & $\mathrm{O}$ & $-€ 7.00$ for sure \\
\hline & $\mathrm{O}$ & $\mathrm{O}$ & $-€ 7.50$ for sure \\
\hline & $\mathrm{O}$ & $\mathrm{O}$ & $-€ 8.00$ for sure \\
\hline & $\mathrm{O}$ & $\mathrm{O}$ & $-€ 8.50$ for sure \\
\hline & $\mathrm{O}$ & $\mathrm{O}$ & $-€ 9.00$ for sure \\
\hline AIT & $\mathrm{O}$ & $\mathrm{O}$ & $-€ 9.50$ for sure \\
\hline & $\mathrm{O}$ & $\mathrm{O}$ & $-€ 10.00$ for sure \\
\hline & $\mathrm{O}$ & $\mathrm{O}$ & $-€ 10.50$ for sure \\
\hline & $\mathrm{O}$ & $\mathrm{O}$ & $-€ 11.00$ for sure \\
\hline & $\mathrm{O}$ & $\mathrm{O}$ & $-€ 11.50$ for sure \\
\hline Lose $€ \mathbf{2 0}$ if one of the following balls is extracted: & $\mathrm{O}$ & $\mathrm{O}$ & $-€ 12.00$ for sure \\
\hline & $\mathrm{O}$ & $\mathrm{O}$ & $-€ 12.50$ for sure \\
\hline & $\mathrm{O}$ & $\mathrm{O}$ & $-€ 13.00$ for sure \\
\hline Lose $\boldsymbol{E} \mathbf{5}$ if one of the following balls is extracted: & $\mathrm{O}$ & $\mathrm{O}$ & $-€ 13.50$ for sure \\
\hline & $\mathrm{O}$ & $\mathrm{O}$ & $-€ 14.00$ for sure \\
\hline & $\mathrm{O}$ & $\mathrm{O}$ & $-€ 14.50$ for sure \\
\hline & $\mathrm{O}$ & $\mathrm{O}$ & $-€ 15.00$ for sure \\
\hline & $\mathrm{O}$ & $\mathrm{O}$ & $-€ 15.50$ for sure \\
\hline & $\mathrm{O}$ & $\mathrm{O}$ & $-€ 16.00$ for sure \\
\hline & $\mathrm{O}$ & $\mathrm{O}$ & $-€ 16.50$ for sure \\
\hline & $\mathrm{O}$ & $\mathrm{O}$ & $-€ 17.00$ for sure \\
\hline & $\mathrm{O}$ & $\mathrm{O}$ & $-€ 17.50$ for sure \\
\hline & $\mathrm{O}$ & $\mathrm{O}$ & $-€ 18.00$ for sure \\
\hline & $\mathrm{O}$ & $\mathrm{O}$ & $-€ 18.50$ for sure \\
\hline & $\mathrm{O}$ & $\mathrm{O}$ & $-€ 19.00$ for sure \\
\hline & $\mathrm{O}$ & $\mathrm{O}$ & $-€ 19.50$ for sure \\
\hline
\end{tabular}




\section{Decision II-14}

\begin{tabular}{|c|c|c|c|}
\hline & Lottery & $\mathrm{Su}$ & \\
\hline & $\mathrm{O}$ & $\mathrm{O}$ & $-€ 0.50$ for sure \\
\hline & $\mathrm{O}$ & $\mathrm{O}$ & $-€ 1.00$ for sure \\
\hline & $\mathrm{O}$ & $\mathrm{O}$ & $-€ 1.50$ for sure \\
\hline & $\mathrm{O}$ & $\mathrm{O}$ & $-€ 2.00$ for sure \\
\hline & $\mathrm{O}$ & $\mathrm{O}$ & $-€ 2.50$ for sure \\
\hline & $\mathrm{O}$ & $\mathrm{O}$ & $-€ 3.00$ for sure \\
\hline & $\mathrm{O}$ & $\mathrm{O}$ & $-€ 3.50$ for sure \\
\hline & $\mathrm{O}$ & $\mathrm{O}$ & $-€ 4.00$ for sure \\
\hline S[II] & $\mathrm{O}$ & $\mathrm{O}$ & $-€ 4.50$ for sure \\
\hline & $\mathrm{O}$ & $\mathrm{O}$ & $-€ 5.00$ for sure \\
\hline & $\mathrm{O}$ & $\mathrm{O}$ & $-€ 5.50$ for sure \\
\hline & $\mathrm{O}$ & $\mathrm{O}$ & $-€ 6.00$ for sure \\
\hline & $\mathrm{O}$ & $\mathrm{O}$ & $-€ 6.50$ for sure \\
\hline Lose $€ 20$ if one of the following balls is extracted: & $\mathrm{O}$ & $\mathrm{O}$ & $-€ 7.00$ for sure \\
\hline 1 & $\mathrm{O}$ & $\mathrm{O}$ & $-€ 7.50$ for sure \\
\hline & $\mathrm{O}$ & $\mathrm{O}$ & $-€ 8.00$ for sure \\
\hline Lose $\boldsymbol{E} \mathbf{0}$ if one of the following balls is extracted: & $\mathrm{O}$ & $\mathrm{O}$ & $-€ 8.50$ for sure \\
\hline & $\mathrm{O}$ & $\mathrm{O}$ & $-€ 9.00$ for sure \\
\hline & $\mathrm{O}$ & $\mathrm{O}$ & $-€ 9.50$ for sure \\
\hline & $\mathrm{O}$ & $\mathrm{O}$ & $-€ 10.00$ for sure \\
\hline & $\mathrm{O}$ & $\mathrm{O}$ & $-€ 10.50$ for sure \\
\hline & $\mathrm{O}$ & $\mathrm{O}$ & $-€ 11.00$ for sure \\
\hline & $\mathrm{O}$ & $\mathrm{O}$ & $-€ 11.50$ for sure \\
\hline & $\mathrm{O}$ & $\mathrm{O}$ & $-€ 12.00$ for sure \\
\hline & $\mathrm{O}$ & $\mathrm{O}$ & $-€ 12.50$ for sure \\
\hline & $\mathrm{O}$ & $\mathrm{O}$ & $-€ 13.00$ for sure \\
\hline & $\mathrm{O}$ & $\mathrm{O}$ & $-€ 13.50$ for sure \\
\hline & $\mathrm{O}$ & $\mathrm{O}$ & $-€ 14.00$ for sure \\
\hline & $\mathrm{O}$ & $\mathrm{O}$ & $-€ 14.50$ for sure \\
\hline & $\mathrm{O}$ & $\mathrm{O}$ & $-€ 15.00$ for sure \\
\hline & $\mathrm{O}$ & $\mathrm{O}$ & $-€ 15.50$ for sure \\
\hline & $\mathrm{O}$ & $\mathrm{O}$ & $-€ 16.00$ for sure \\
\hline & $\mathrm{O}$ & $\mathrm{O}$ & $-€ 16.50$ for sure \\
\hline & $\mathrm{O}$ & $\mathrm{O}$ & $-€ 17.00$ for sure \\
\hline & $\mathrm{O}$ & $\mathrm{O}$ & $-€ 17.50$ for sure \\
\hline & $\mathrm{O}$ & $\mathrm{O}$ & $-€ 18.00$ for sure \\
\hline & $\mathrm{O}$ & $\mathrm{O}$ & $-€ 18.50$ for sure \\
\hline & $\mathrm{O}$ & $\mathrm{O}$ & $-€ 19.00$ for sure \\
\hline & $\mathrm{O}$ & $\mathrm{O}$ & $-€ 19.50$ for sure \\
\hline
\end{tabular}




\section{Decision II-15}

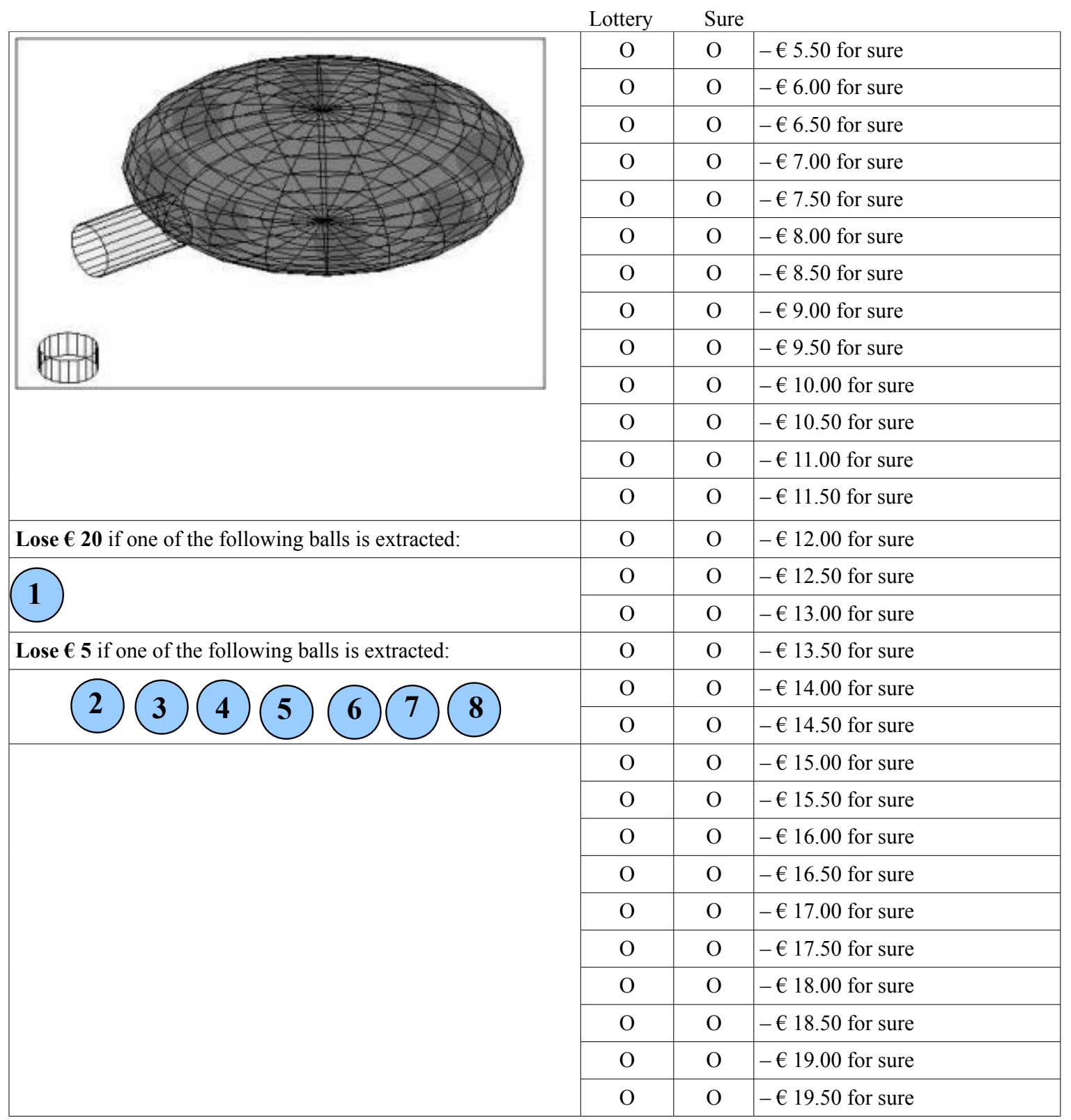




\section{Decision II-16}

\begin{tabular}{|c|c|c|c|}
\hline & ottery & $\mathrm{Su}$ & \\
\hline & $\mathrm{O}$ & $\mathrm{O}$ & $-€ 0.50$ for sure \\
\hline & $\mathrm{O}$ & $\mathrm{O}$ & $-€ 1.00$ for sure \\
\hline & $\mathrm{O}$ & $\mathrm{O}$ & $-€ 1.50$ for sure \\
\hline & $\mathrm{O}$ & $\mathrm{O}$ & $-€ 2.00$ for sure \\
\hline & $\mathrm{O}$ & $\mathrm{O}$ & $-€ 2.50$ for sure \\
\hline & $\mathrm{O}$ & $\mathrm{O}$ & $-€ 3.00$ for sure \\
\hline & $\mathrm{O}$ & $\mathrm{O}$ & $-€ 3.50$ for sure \\
\hline & $\mathrm{O}$ & $\mathrm{O}$ & $-€ 4.00$ for sure \\
\hline & $\mathrm{O}$ & $\mathrm{O}$ & $-€ 4.50$ for sure \\
\hline & $\mathrm{O}$ & $\mathrm{O}$ & $-€ 5.00$ for sure \\
\hline & $\mathrm{O}$ & $\mathrm{O}$ & $-€ 5.50$ for sure \\
\hline & $\mathrm{O}$ & $\mathrm{O}$ & $-€ 6.00$ for sure \\
\hline & $\mathrm{O}$ & $\mathrm{O}$ & $-€ 6.50$ for sure \\
\hline Lose $€ 20$ if one of the following balls is extracted: & $\mathrm{O}$ & $\mathrm{O}$ & $-€ 7.00$ for sure \\
\hline & $\mathrm{O}$ & $\mathrm{O}$ & $-€ 7.50$ for sure \\
\hline & $\mathrm{O}$ & $\mathrm{O}$ & $-€ 8.00$ for sure \\
\hline Lose $€ 0$ if one of the following balls is extracted: & $\mathrm{O}$ & $\mathrm{O}$ & $-€ 8.50$ for sure \\
\hline & $\mathrm{O}$ & $\mathrm{O}$ & $-€ 9.00$ for sure \\
\hline & $\mathrm{O}$ & $\mathrm{O}$ & $-€ 9.50$ for sure \\
\hline & $\mathrm{O}$ & $\mathrm{O}$ & $-€ 10.00$ for sure \\
\hline & $\mathrm{O}$ & $\mathrm{O}$ & $-€ 10.50$ for sure \\
\hline & $\mathrm{O}$ & $\mathrm{O}$ & $-€ 11.00$ for sure \\
\hline & $\mathrm{O}$ & $\mathrm{O}$ & $-€ 11.50$ for sure \\
\hline & $\mathrm{O}$ & $\mathrm{O}$ & $-€ 12.00$ for sure \\
\hline & $\mathrm{O}$ & $\mathrm{O}$ & $-€ 12.50$ for sure \\
\hline & $\mathrm{O}$ & $\mathrm{O}$ & $-€ 13.00$ for sure \\
\hline & $\mathrm{O}$ & $\mathrm{O}$ & $-€ 13.50$ for sure \\
\hline & $\mathrm{O}$ & $\mathrm{O}$ & $-€ 14.00$ for sure \\
\hline & $\mathrm{O}$ & $\mathrm{O}$ & $-€ 14.50$ for sure \\
\hline & $\mathrm{O}$ & $\mathrm{O}$ & $-€ 15.00$ for sure \\
\hline & $\mathrm{O}$ & $\mathrm{O}$ & $-€ 15.50$ for sure \\
\hline & $\mathrm{O}$ & $\mathrm{O}$ & $-€ 16.00$ for sure \\
\hline & $\mathrm{O}$ & $\mathrm{O}$ & $-€ 16.50$ for sure \\
\hline & $\mathrm{O}$ & $\mathrm{O}$ & $-€ 17.00$ for sure \\
\hline & $\mathrm{O}$ & $\mathrm{O}$ & $-€ 17.50$ for sure \\
\hline & $\mathrm{O}$ & $\mathrm{O}$ & $-€ 18.00$ for sure \\
\hline & $\mathrm{O}$ & $\mathrm{O}$ & $-€ 18.50$ for sure \\
\hline & $\mathrm{O}$ & $\mathrm{O}$ & $-€ 19.00$ for sure \\
\hline & $\mathrm{O}$ & $\mathrm{O}$ & $-€ 19.50$ for sure \\
\hline
\end{tabular}


Decision II-17

Lottery Sure

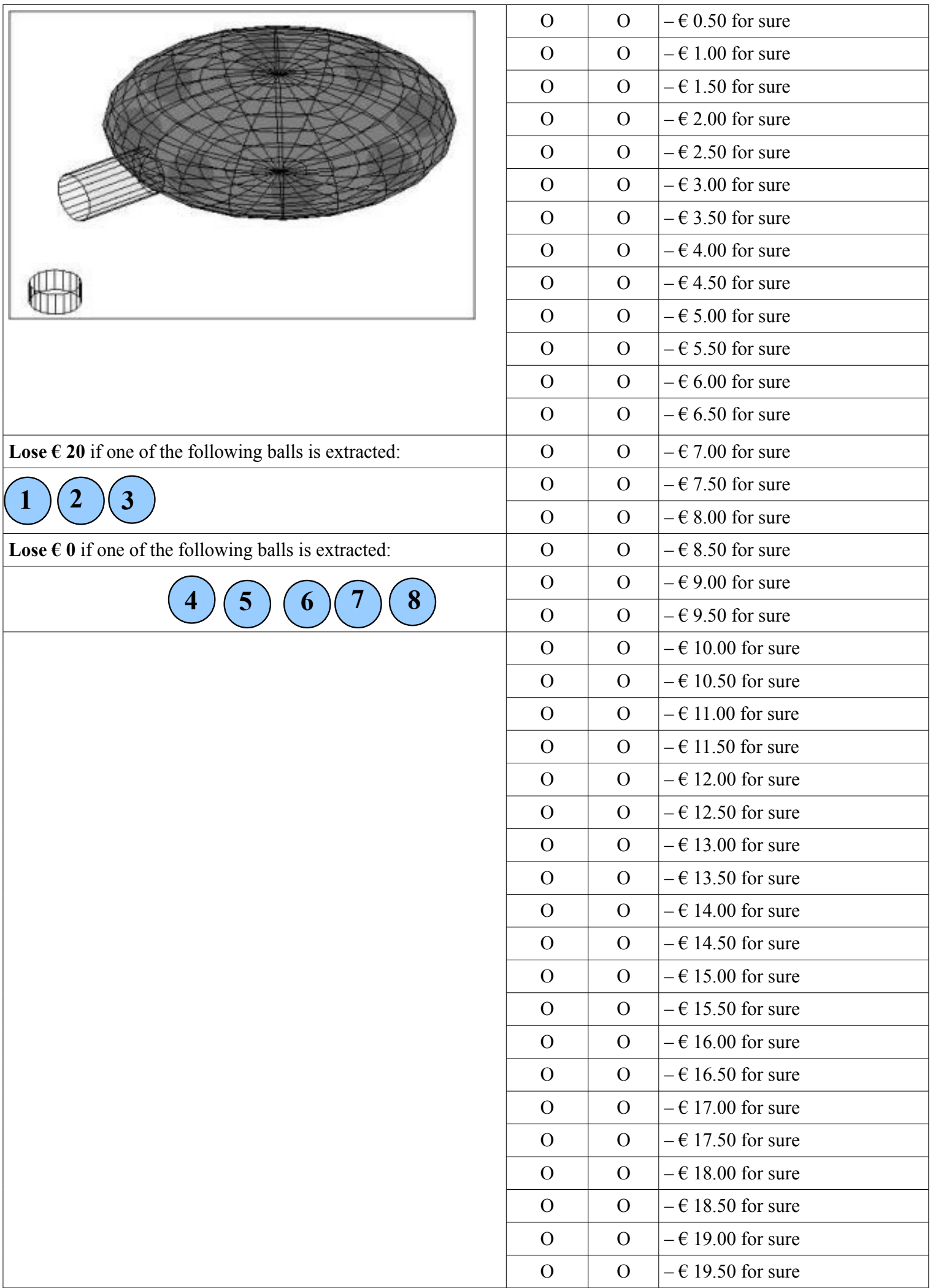




\section{Decision II-18}

\begin{tabular}{|c|c|c|c|}
\hline & ottery & $\mathrm{Su}$ & \\
\hline & $\mathrm{O}$ & $\mathrm{O}$ & $-€ 0.50$ for sure \\
\hline & $\mathrm{O}$ & $\mathrm{O}$ & $-€ 1.00$ for sure \\
\hline & $\mathrm{O}$ & $\mathrm{O}$ & $-€ 1.50$ for sure \\
\hline & $\mathrm{O}$ & $\mathrm{O}$ & $-€ 2.00$ for sure \\
\hline & $\mathrm{O}$ & $\mathrm{O}$ & $-€ 2.50$ for sure \\
\hline & $\mathrm{O}$ & $\mathrm{O}$ & $-€ 3.00$ for sure \\
\hline & $\mathrm{O}$ & $\mathrm{O}$ & $-€ 3.50$ for sure \\
\hline & $\mathrm{O}$ & $\mathrm{O}$ & $-€ 4.00$ for sure \\
\hline & $\mathrm{O}$ & $\mathrm{O}$ & $-€ 4.50$ for sure \\
\hline & $\mathrm{O}$ & $\mathrm{O}$ & $-€ 5.00$ for sure \\
\hline & $\mathrm{O}$ & $\mathrm{O}$ & $-€ 5.50$ for sure \\
\hline & $\mathrm{O}$ & $\mathrm{O}$ & $-€ 6.00$ for sure \\
\hline & $\mathrm{O}$ & $\mathrm{O}$ & $-€ 6.50$ for sure \\
\hline Lose $€ 20$ if one of the following balls is extracted: & $\mathrm{O}$ & $\mathrm{O}$ & $-€ 7.00$ for sure \\
\hline & $\mathrm{O}$ & $\mathrm{O}$ & $-€ 7.50$ for sure \\
\hline & $\mathrm{O}$ & $\mathrm{O}$ & $-€ 8.00$ for sure \\
\hline Lose $€ 0$ if one of the following balls is extracted: & $\mathrm{O}$ & $\mathrm{O}$ & $-€ 8.50$ for sure \\
\hline & $\mathrm{O}$ & $\mathrm{O}$ & $-€ 9.00$ for sure \\
\hline & $\mathrm{O}$ & $\mathrm{O}$ & $-€ 9.50$ for sure \\
\hline & $\mathrm{O}$ & $\mathrm{O}$ & $-€ 10.00$ for sure \\
\hline & $\mathrm{O}$ & $\mathrm{O}$ & $-€ 10.50$ for sure \\
\hline & $\mathrm{O}$ & $\mathrm{O}$ & $-€ 11.00$ for sure \\
\hline & $\mathrm{O}$ & $\mathrm{O}$ & $-€ 11.50$ for sure \\
\hline & $\mathrm{O}$ & $\mathrm{O}$ & $-€ 12.00$ for sure \\
\hline & $\mathrm{O}$ & $\mathrm{O}$ & $-€ 12.50$ for sure \\
\hline & $\mathrm{O}$ & $\mathrm{O}$ & $-€ 13.00$ for sure \\
\hline & $\mathrm{O}$ & $\mathrm{O}$ & $-€ 13.50$ for sure \\
\hline & $\mathrm{O}$ & $\mathrm{O}$ & $-€ 14.00$ for sure \\
\hline & $\mathrm{O}$ & $\mathrm{O}$ & $-€ 14.50$ for sure \\
\hline & $\mathrm{O}$ & $\mathrm{O}$ & $-€ 15.00$ for sure \\
\hline & $\mathrm{O}$ & $\mathrm{O}$ & $-€ 15.50$ for sure \\
\hline & $\mathrm{O}$ & $\mathrm{O}$ & $-€ 16.00$ for sure \\
\hline & $\mathrm{O}$ & $\mathrm{O}$ & $-€ 16.50$ for sure \\
\hline & $\mathrm{O}$ & $\mathrm{O}$ & $-€ 17.00$ for sure \\
\hline & $\mathrm{O}$ & $\mathrm{O}$ & $-€ 17.50$ for sure \\
\hline & $\mathrm{O}$ & $\mathrm{O}$ & $-€ 18.00$ for sure \\
\hline & $\mathrm{O}$ & $\mathrm{O}$ & $-€ 18.50$ for sure \\
\hline & $\mathrm{O}$ & $\mathrm{O}$ & $-€ 19.00$ for sure \\
\hline & $\mathrm{O}$ & $\mathrm{O}$ & $-€ 19.50$ for sure \\
\hline
\end{tabular}




\section{Decision II-19}

\begin{tabular}{|c|c|c|c|}
\hline & Lottery & $\mathrm{Su}$ & \\
\hline & $\mathrm{O}$ & $\mathrm{O}$ & $-€ 0.50$ for sure \\
\hline & $\mathrm{O}$ & $\mathrm{O}$ & $-€ 1.00$ for sure \\
\hline & $\mathrm{O}$ & $\mathrm{O}$ & $-€ 1.50$ for sure \\
\hline & $\mathrm{O}$ & $\mathrm{O}$ & $-€ 2.00$ for sure \\
\hline & $\mathrm{O}$ & $\mathrm{O}$ & $-€ 2.50$ for sure \\
\hline & $\mathrm{O}$ & $\mathrm{O}$ & $-€ 3.00$ for sure \\
\hline & $\mathrm{O}$ & $\mathrm{O}$ & $-€ 3.50$ for sure \\
\hline & $\mathrm{O}$ & $\mathrm{O}$ & $-€ 4.00$ for sure \\
\hline SIIIT & $\mathrm{O}$ & $\mathrm{O}$ & $-€ 4.50$ for sure \\
\hline & $\mathrm{O}$ & $\mathrm{O}$ & $-€ 5.00$ for sure \\
\hline & $\mathrm{O}$ & $\mathrm{O}$ & $-€ 5.50$ for sure \\
\hline & $\mathrm{O}$ & $\mathrm{O}$ & $-€ 6.00$ for sure \\
\hline & $\mathrm{O}$ & $\mathrm{O}$ & $-€ 6.50$ for sure \\
\hline Lose $€ 20$ if one of the following balls is extracted: & $\mathrm{O}$ & $\mathrm{O}$ & $-€ 7.00$ for sure \\
\hline & $\mathrm{O}$ & $\mathrm{O}$ & $-€ 7.50$ for sure \\
\hline & $\mathrm{O}$ & $\mathrm{O}$ & $-€ 8.00$ for sure \\
\hline Lose $\boldsymbol{E} \mathbf{0}$ if one of the following balls is extracted: & $\mathrm{O}$ & $\mathrm{O}$ & $-€ 8.50$ for sure \\
\hline & $\mathrm{O}$ & $\mathrm{O}$ & $-€ 9.00$ for sure \\
\hline & $\mathrm{O}$ & $\mathrm{O}$ & $-€ 9.50$ for sure \\
\hline & $\mathrm{O}$ & $\mathrm{O}$ & $-€ 10.00$ for sure \\
\hline & $\mathrm{O}$ & $\mathrm{O}$ & $-€ 10.50$ for sure \\
\hline & $\mathrm{O}$ & $\mathrm{O}$ & $-€ 11.00$ for sure \\
\hline & $\mathrm{O}$ & $\mathrm{O}$ & $-€ 11.50$ for sure \\
\hline & $\mathrm{O}$ & $\mathrm{O}$ & $-€ 12.00$ for sure \\
\hline & $\mathrm{O}$ & $\mathrm{O}$ & $-€ 12.50$ for sure \\
\hline & $\mathrm{O}$ & $\mathrm{O}$ & $-€ 13.00$ for sure \\
\hline & $\mathrm{O}$ & $\mathrm{O}$ & $-€ 13.50$ for sure \\
\hline & $\mathrm{O}$ & $\mathrm{O}$ & $-€ 14.00$ for sure \\
\hline & $\mathrm{O}$ & $\mathrm{O}$ & $-€ 14.50$ for sure \\
\hline & $\mathrm{O}$ & $\mathrm{O}$ & $-€ 15.00$ for sure \\
\hline & $\mathrm{O}$ & $\mathrm{O}$ & $-€ 15.50$ for sure \\
\hline & $\mathrm{O}$ & $\mathrm{O}$ & $-€ 16.00$ for sure \\
\hline & $\mathrm{O}$ & $\mathrm{O}$ & $-€ 16.50$ for sure \\
\hline & $\mathrm{O}$ & $\mathrm{O}$ & $-€ 17.00$ for sure \\
\hline & $\mathrm{O}$ & $\mathrm{O}$ & $-€ 17.50$ for sure \\
\hline & $\mathrm{O}$ & $\mathrm{O}$ & $-€ 18.00$ for sure \\
\hline & $\mathrm{O}$ & $\mathrm{O}$ & $-€ 18.50$ for sure \\
\hline & $\mathrm{O}$ & $\mathrm{O}$ & $-€ 19.00$ for sure \\
\hline & $\mathrm{O}$ & $\mathrm{O}$ & $-€ 19.50$ for sure \\
\hline
\end{tabular}




\section{Decision II-20}

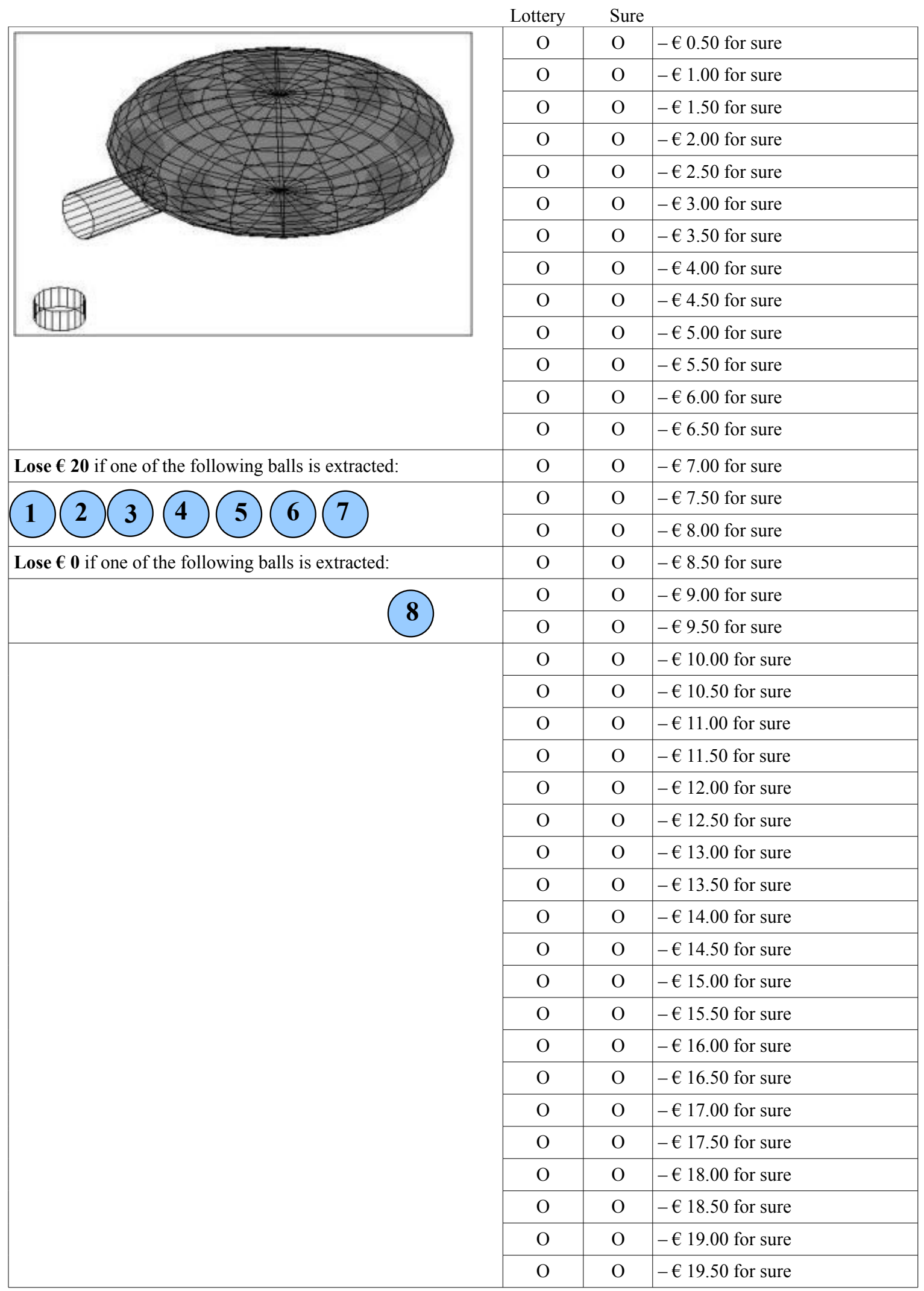




\section{Decision II-21}

\begin{tabular}{|c|c|c|c|}
\hline \multicolumn{2}{|r|}{ Lottery } & \multicolumn{2}{|c|}{ Sure } \\
\hline \multirow{13}{*}{ (1III) } & $\mathrm{O}$ & $\mathrm{O}$ & $-€ 5.50$ for sure \\
\hline & $\mathrm{O}$ & $\mathrm{O}$ & $-€ 6.00$ for sure \\
\hline & $\mathrm{O}$ & $\mathrm{O}$ & $-€ 6.50$ for sure \\
\hline & $\mathrm{O}$ & $\mathrm{O}$ & $-€ 7.00$ for sure \\
\hline & $\mathrm{O}$ & $\mathrm{O}$ & $-€ 7.50$ for sure \\
\hline & $\mathrm{O}$ & $\mathrm{O}$ & $-€ 8.00$ for sure \\
\hline & $\mathrm{O}$ & $\mathrm{O}$ & $-€ 8.50$ for sure \\
\hline & $\mathrm{O}$ & $\mathrm{O}$ & $-€ 9.00$ for sure \\
\hline & $\mathrm{O}$ & $\mathrm{O}$ & $-€ 9.50$ for sure \\
\hline & $\mathrm{O}$ & $\mathrm{O}$ & $-€ 10.00$ for sure \\
\hline & $\mathrm{O}$ & $\mathrm{O}$ & $-€ 10.50$ for sure \\
\hline & $\mathrm{O}$ & $\mathrm{O}$ & $-€ 11.00$ for sure \\
\hline & $\mathrm{O}$ & $\mathrm{O}$ & $-€ 11.50$ for sure \\
\hline \multirow[t]{3}{*}{ Lose $€ 20$ if one of the following balls is extracted: } & $\mathrm{O}$ & $\mathrm{O}$ & $-€ 12.00$ for sure \\
\hline & $\mathrm{O}$ & $\mathrm{O}$ & $-€ 12.50$ for sure \\
\hline & $\mathrm{O}$ & $\mathrm{O}$ & $-€ 13.00$ for sure \\
\hline \multirow[t]{13}{*}{ Lose $\boldsymbol{\epsilon}$ if one of the following balls is extracted: } & $\mathrm{O}$ & $\mathrm{O}$ & $-€ 13.50$ for sure \\
\hline & $\mathrm{O}$ & $\mathrm{O}$ & $-€ 14.00$ for sure \\
\hline & $\mathrm{O}$ & $\mathrm{O}$ & $-€ 14.50$ for sure \\
\hline & $\mathrm{O}$ & $\mathrm{O}$ & $-€ 15.00$ for sure \\
\hline & $\mathrm{O}$ & $\mathrm{O}$ & $-€ 15.50$ for sure \\
\hline & $\mathrm{O}$ & $\mathrm{O}$ & $-€ 16.00$ for sure \\
\hline & $\mathrm{O}$ & $\mathrm{O}$ & $-€ 16.50$ for sure \\
\hline & $\mathrm{O}$ & $\mathrm{O}$ & $-€ 17.00$ for sure \\
\hline & $\mathrm{O}$ & $\mathrm{O}$ & $-€ 17.50$ for sure \\
\hline & $\mathrm{O}$ & $\mathrm{O}$ & $-€ 18.00$ for sure \\
\hline & $\mathrm{O}$ & $\mathrm{O}$ & $-€ 18.50$ for sure \\
\hline & $\mathrm{O}$ & $\mathrm{O}$ & $-€ 19.00$ for sure \\
\hline & $\mathrm{O}$ & $\mathrm{O}$ & $-€ 19.50$ for sure \\
\hline
\end{tabular}




\section{Decision II-22}

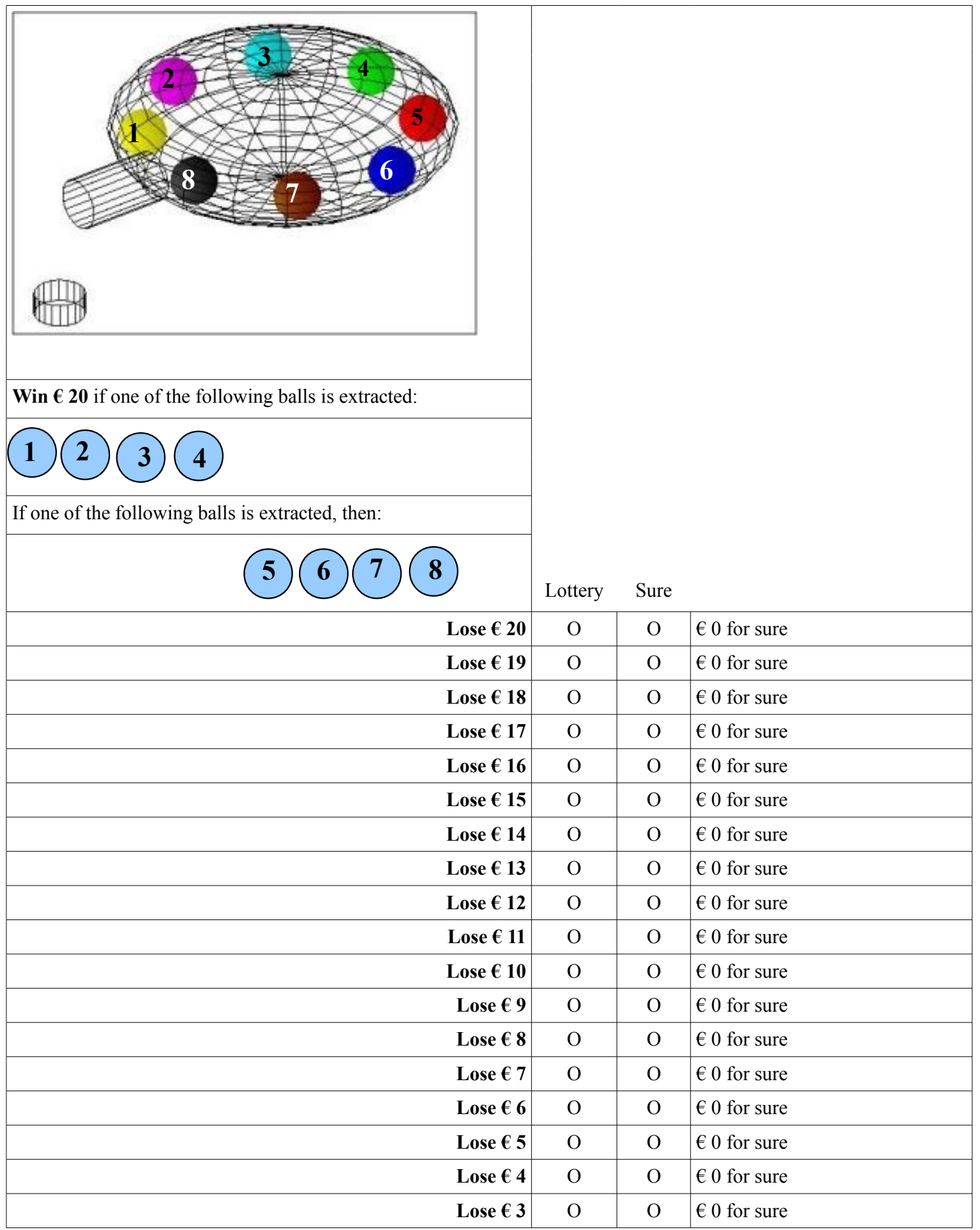




\section{Questionnaire}

Please answer the following questions about yourself. All answers are confidential and cannot be traced back to you personally.

Age:

Study semester:

O female O male

What is your studies major?

O economics or business

O mathematics or engineering

O natural sciences

O medicine

O social sciences

O humanities

$\mathrm{O}$ arts

O other

Please indicate your grade point average:

Are you originally from $\$ \$$ name of country where exp. is to take place $\$ \$ ? \quad$ O yes $\quad \mathrm{O}$ no

If not, which country are you from originally?

Are both your parents from $\$ \$$ name of country where exp. is to take place $\$ \$$ O yes $\quad$ O no

Have you ever lived abroad for a significant period of time?

O never

$\mathrm{O}$ less than six months

$\mathrm{O}$ between six months and a year

$\mathrm{O}$ between one and two years

$O$ between two and five years

O longer than five years

Could you give a rough indication of your monthly living expenses?

Could you give a rough indication of your monthly stipend?

Please indicate how many older siblings you have:

Please indicate how many younger siblings you have:

Are you married? O yes $\mathrm{O}$ no

How tall are you? $\mathrm{cm}$

Please consider the following statement: "Man-induced climate change is a serious danger that could threaten our way of life". Please indicate on the scale below the extent to which you agree with this statement, with 1 indicating "I don't agree at all" and 7 indicating "I fully agree":

$\begin{array}{lllllll}1 & 2 & 3 & 4 & 5 & 6 & 7 \\ \mathrm{O} & \mathrm{O} & \mathrm{O} & \mathrm{O} & \mathrm{O} & \mathrm{O} & \mathrm{O}\end{array}$

Please consider the following statement: "It is imperative to take immediate action to limit potential catastrophic consequences from changes in global climate, even if such action may be costly". Please indicate on the scale below the extent to which you agree with this statement, with 1 indicating "I don't agree at all" and 7 indicating "I fully agree":

$\begin{array}{lllllll}1 & 2 & 3 & 4 & 5 & 6 & 7 \\ \mathrm{O} & \mathrm{O} & \mathrm{O} & \mathrm{O} & \mathrm{O} & \mathrm{O} & \mathrm{O}\end{array}$


The following section seeks to evaluate your cultural orientation. Please indicate your agreement with each of the following statements:

\begin{tabular}{|c|c|c|c|c|c|}
\hline & $\begin{array}{l}\text { Stongly } \\
\text { disagree }\end{array}$ & Disagree & $\begin{array}{l}\text { Neither agree } \\
\text { nor disagree }\end{array}$ & Agree & $\begin{array}{c}\text { Strongly } \\
\text { agree }\end{array}$ \\
\hline 1. Individuals should sacrifice self-interest for the group that they belong to & $\mathrm{O}$ & $\mathrm{O}$ & $\mathrm{O}$ & $\mathrm{O}$ & $\mathrm{O}$ \\
\hline 3. Group welfare is more important than individual rewards & $\mathrm{O}$ & $\mathrm{O}$ & $\mathrm{O}$ & $\mathrm{O}$ & $\mathrm{O}$ \\
\hline 4. Group success is more important than individual success & $\mathrm{O}$ & $\mathrm{O}$ & $\mathrm{O}$ & $\mathrm{O}$ & $\mathrm{O}$ \\
\hline 6. Group loyalty should be encouraged even if individual goals suffer & $\mathrm{O}$ & $\mathrm{O}$ & $\mathrm{O}$ & $\mathrm{O}$ & $\mathrm{O}$ \\
\hline $\begin{array}{l}\text { 7. People in higher positions should make most decisions without consulting people } \\
\text { in lower positions }\end{array}$ & $\mathrm{O}$ & $\mathrm{O}$ & $\mathrm{O}$ & $\mathrm{O}$ & $\mathrm{O}$ \\
\hline $\begin{array}{l}\text { 8. People in higher positions should not delegate important tasks to people in lower } \\
\text { positions }\end{array}$ & $\mathrm{O}$ & $\mathrm{O}$ & $\mathrm{O}$ & $\mathrm{O}$ & $\mathrm{O}$ \\
\hline $\begin{array}{l}\text { 11. People in lower positions should not disagree with decisions made by people in } \\
\text { higher positions }\end{array}$ & $\mathrm{O}$ & $\mathrm{O}$ & $\mathrm{O}$ & $\mathrm{O}$ & $\mathrm{O}$ \\
\hline $\begin{array}{l}\text { 12. It is important to have instructions spelled out in detail so that I always know } \\
\text { what I am expected to do }\end{array}$ & $\mathrm{O}$ & $\mathrm{O}$ & $\mathrm{O}$ & $\mathrm{O}$ & $\mathrm{O}$ \\
\hline 13. It is important to closely follow instructions and procedures & $\mathrm{O}$ & $\mathrm{O}$ & $\mathrm{O}$ & $\mathrm{O}$ & $\mathrm{O}$ \\
\hline $\begin{array}{l}\text { 14. Rules/regulations are important because they inform me of what is expected of } \\
\text { me }\end{array}$ & $\mathrm{O}$ & $\mathrm{O}$ & $\mathrm{O}$ & $\mathrm{O}$ & $\mathrm{O}$ \\
\hline 15. Standardized work procedures are helpful & $\mathrm{O}$ & $\mathrm{O}$ & $\mathrm{O}$ & $\mathrm{O}$ & $\mathrm{O}$ \\
\hline 20. There are some jobs that a man can always do better than a woman & $\mathrm{O}$ & $\mathrm{O}$ & $\mathrm{O}$ & $\mathrm{O}$ & $\mathrm{O}$ \\
\hline $\begin{array}{l}\text { 21. Even though certain food products are available in a number of different flavors, } \\
\text { I tend to buy the same flavor }\end{array}$ & $\mathrm{O}$ & $\mathrm{O}$ & $\mathrm{O}$ & $\mathrm{O}$ & $\mathrm{O}$ \\
\hline $\begin{array}{l}\text { 22. I would rather stick with a brand I usually buy than try something I am not very } \\
\text { sure of }\end{array}$ & $\mathrm{O}$ & $\mathrm{O}$ & $\mathrm{O}$ & $\mathrm{O}$ & $\mathrm{O}$ \\
\hline 23. I think of myself as a brand-loyal consumer & $\mathrm{O}$ & $\mathrm{O}$ & $\mathrm{O}$ & $\mathrm{O}$ & $\mathrm{O}$ \\
\hline 24. When I go to a restaurant, I feel it is safer to order dishes I am familiar with & $\mathrm{O}$ & $\mathrm{O}$ & $\mathrm{O}$ & $\mathrm{O}$ & $\mathrm{O}$ \\
\hline 25. If I like a brand, I rarely switch from it just to try something different & $\mathrm{O}$ & $\mathrm{O}$ & $\mathrm{O}$ & $\mathrm{O}$ & $\mathrm{O}$ \\
\hline 26. I am very cautious in trying new or different products & $\mathrm{O}$ & $\mathrm{O}$ & $\mathrm{O}$ & $\mathrm{O}$ & $\mathrm{O}$ \\
\hline 27. I rarely buy brands about which I am uncertain how they will perform & $\mathrm{O}$ & $\mathrm{O}$ & $\mathrm{O}$ & $\mathrm{O}$ & $\mathrm{O}$ \\
\hline 28. I usually eat the same kinds of foods on a regular basis & $\mathrm{O}$ & $\mathrm{O}$ & $\mathrm{O}$ & $\mathrm{O}$ & $\mathrm{O}$ \\
\hline
\end{tabular}

How do you see yourself? Are you generally a person who is fully willing to take risks or do you try to avoid taking risks? Please tick a box on the scale below, where 0 means "risk averse" and 10 means "fully prepared to take risks":

Risk averse

$\begin{array}{lllllllllll}\mathbf{0} & \mathbf{1} & \mathbf{2} & \mathbf{3} & \mathbf{4} & \mathbf{5} & \mathbf{6} & \mathbf{7} & \mathbf{8} & \mathbf{9} & \mathbf{1 0} \\ \mathrm{O} & \mathrm{O} & \mathrm{O} & \mathrm{O} & \mathrm{O} & \mathrm{O} & \mathrm{O} & \mathrm{O} & \mathrm{O} & \mathrm{O} & \mathrm{O}\end{array}$


People can behave differently in different situations.

How would you rate your willingness to take risks in the following areas?

How is it ...

risk averse

fully prepared

risk averse
\begin{tabular}{|c|c|c|c|c|c|c|c|c|c|c|c|}
\hline & $\mathbf{0}$ & $\mathbf{1}$ & $\mathbf{2}$ & $\mathbf{3}$ & $\mathbf{4}$ & $\mathbf{5}$ & $\mathbf{6}$ & $\mathbf{7}$ & $\mathbf{8}$ & $\mathbf{9}$ & $\mathbf{1 0}$ \\
\hline - while driving? & $\mathrm{O}$ & $\mathrm{O}$ & $\mathrm{O}$ & $\mathrm{O}$ & $\mathrm{O}$ & $\mathrm{O}$ & $\mathrm{O}$ & $\mathrm{O}$ & $\mathrm{O}$ & $\mathrm{O}$ & $\mathrm{O}$ \\
\hline - in financial matters? & $\mathrm{O}$ & $\mathrm{O}$ & $\mathrm{O}$ & $\mathrm{O}$ & $\mathrm{O}$ & $\mathrm{O}$ & $\mathrm{O}$ & $\mathrm{O}$ & $\mathrm{O}$ & $\mathrm{O}$ & $\mathrm{O}$ \\
\hline - during leisure and sport? & $\mathrm{O}$ & $\mathrm{O}$ & $\mathrm{O}$ & $\mathrm{O}$ & $\mathrm{O}$ & $\mathrm{O}$ & $\mathrm{O}$ & $\mathrm{O}$ & $\mathrm{O}$ & $\mathrm{O}$ & $\mathrm{O}$ \\
\hline- in your occupation? & $\mathrm{O}$ & $\mathrm{O}$ & $\mathrm{O}$ & $\mathrm{O}$ & $\mathrm{O}$ & $\mathrm{O}$ & $\mathrm{O}$ & $\mathrm{O}$ & $\mathrm{O}$ & $\mathrm{O}$ & $\mathrm{O}$ \\
\hline - with your health? & $\mathrm{O}$ & $\mathrm{O}$ & $\mathrm{O}$ & $\mathrm{O}$ & $\mathrm{O}$ & $\mathrm{O}$ & $\mathrm{O}$ & $\mathrm{O}$ & $\mathrm{O}$ & $\mathrm{O}$ & $\mathrm{O}$ \\
\hline - your faith in other people? & $\mathrm{O}$ & $\mathrm{O}$ & $\mathrm{O}$ & $\mathrm{O}$ & $\mathrm{O}$ & $\mathrm{O}$ & $\mathrm{O}$ & $\mathrm{O}$ & $\mathrm{O}$ & $\mathrm{O}$ & $\mathrm{O}$ \\
\hline
\end{tabular}

Please consider what you would do in the following situation:

Imagine that you had won 100,000 Euros in the lottery. Almost immediately after you collect the winnings, you receive the following financial offer from a reputable bank, the conditions of which are as follows:

There is the chance to double the money within two years. It is equally possible that you could lose half of the amount invested. You have the opportunity to invest the full amount, part of the amount or reject the offer. What share of your lottery winnings would you be prepared to invest in this financially risky, yet lucrative investment?

$\begin{array}{ll}\text { O } & 100.000 \text { Euros } \\ \text { O } & 80.000 \text { Euros } \\ \text { O } & 60.000 \text { Euros } \\ \text { O } & 40.000 \text { Euros } \\ \text { O } & 20.000 \text { Euros } \\ \text { O } & \text { Nothing, I would decline the offer }\end{array}$

How many inhabitants has the town where you lived at the age of $16 ?$

inhabitants

What are your religious views?

$\mathrm{O}$ atheist/agnostic

$\mathrm{O}$ catholic

O protestant

O muslim

O jewish

O hinduist

O buddist

O other:

Thank you for taking part in this experiment! Please remain seated until an experimenter calls you up. 